$$
\begin{aligned}
& \text { CHASING AUD } \\
& \text { RACING } \\
& \text { HARDING Cox }
\end{aligned}
$$



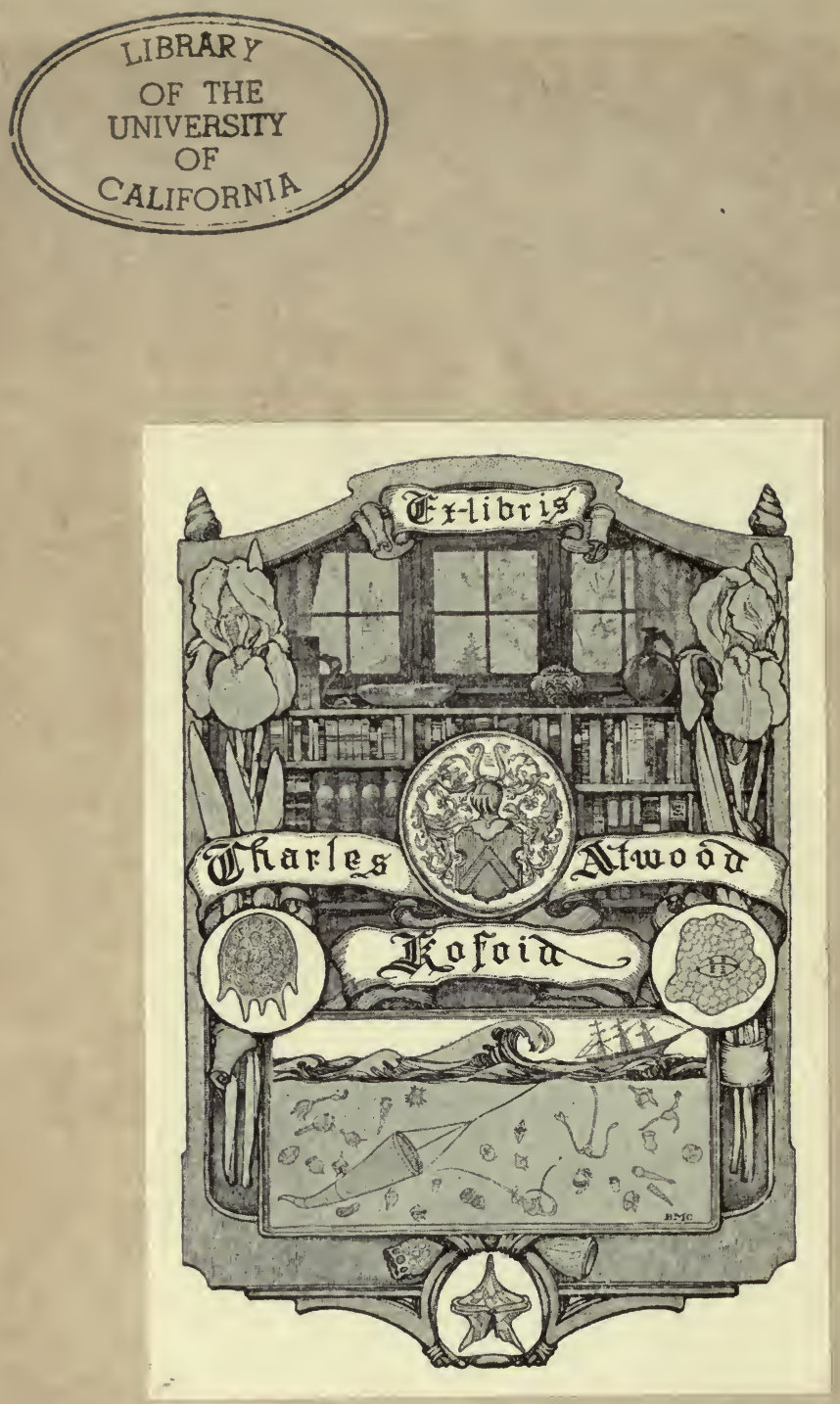

Digitized by the Internet Archive in 2007 with funding from Microsoft Corporation 
CHASING AND RACING 
BY THE SAME AUTHOR

THE AMATEUR'S DERBY

A NOVEL

[In the Press

THE BODLEY HEAD 



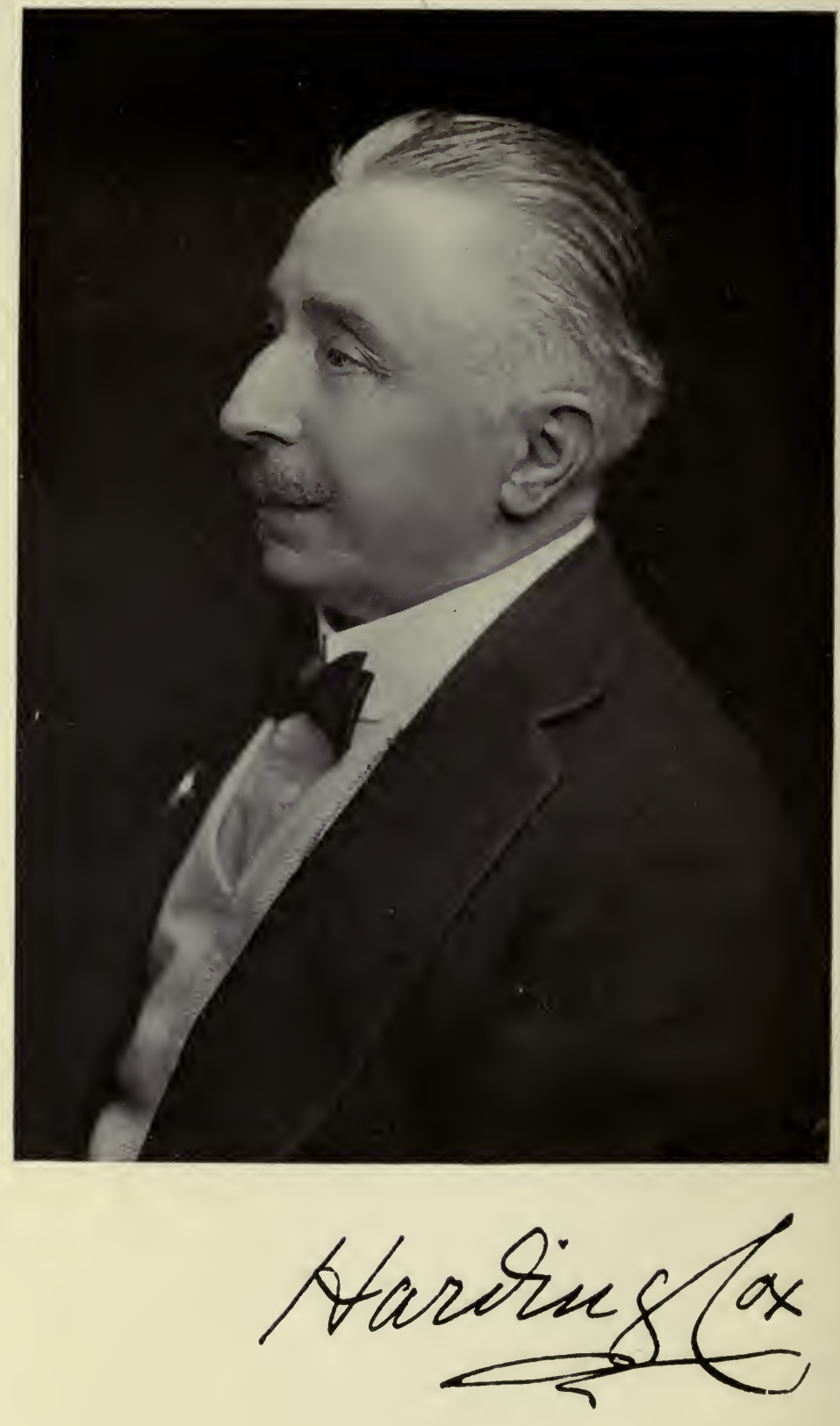




\section{CHASING AND RACING}

SOME SPORTING REMINISCENCES BY HARDING COX

LONDON: JOHN LANE THE BODLEY HEAD LTD. NEW YORK : JOHN LANE COMPANY MCMXXII

The Portrait of the AUthor is from

A Photograph BY

MESSRS, ELLIOTT \& FRY. 



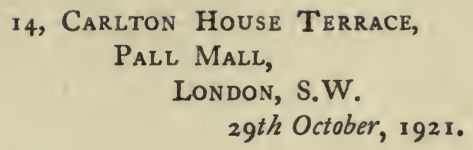

My dear Harding Cox,

You ask me to write a "Foreword" to your "Reminiscences," but I fear I have so little literary talent that I should only disgrace the production. But I am sure your "Reminiscences" will be most interesting, for nobody has a greater experience in all the sports of the world than you have, and whether you are the champion of the lot or not is, to my mind, a very small point. It is the interest people take and their insight into the various branches that count, rather than what they do themselves; and certainly you have always taken an advanced position in that from your early days of Terriers at the Crystal Palace to riding in the Polo Pony Races at Hurlingham, and under Jockey Club and National Hunt rules.

Wishing you all the best of luck,

Believe me,

Yours very truly,

LONSDALE. (Signed.) 


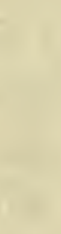




\section{PREFACE}

T $\mathrm{N}$ setting forth my reminiscences of Chasing and Racing, I have taken a rather bold step, inasmuch as my personal experiences as a Master of Harriers and Foxhounds, and as an amateur rider, have been confined to "provincial" packs, and for the most part, as regards race riding, to very moderate specimens of the equine race; but as one who loved the hounds which he hunted, and the "blood" which carried him under Jockey Club and National Hunt rules, I venture to hope that the idiosyncrasies, and what I may term the "personalities," of these inconspicuous animals, will appeal to those who take a real interest in hounds, hunters, and racehorses, apart from their face value as means to an end only-as pawns in the great games of the hunting-field and the racecourse respectively.

I had hoped that the portraits of some of the canine and equine heroes and heroines which figure in these pages might appear in this volume; but, by an evil stroke of luck, all my albums containing these counterfeit presentments were, a few years ago, 
destroyed in a devastating fire, which levelled to the ground the repository in which they had been stored during one of my many migrations. And with them perished all those notes, diaries, and cuttings, on which I had relied for my data; so that only the ashes of memory remained to stimulate my pen. On this ephemeral faculty of memory, therefore, I have had to rely entirely; so I trust that such readers as I may have will make due allowance for any inaccuracies or anachronisms which may appear in the following pages. I had set forth on my labour of love to chronicle my rambling reminiscences in many connections besides Chasing and Racing, such as coursing, shooting, angling, rowing, and various other experiences; but I soon found that the great games of hunting and racing exhausted the space allotted to me. If the fates are propitious I may yet have an opportunity for dealing with these other ventures in which I have exploited my sporting tastes and ambitions.

HARDING COX. 


\section{CONTENTS}

\section{CHAPTER I}

My first mount-My first sight of "colours "-Two turf yarnsSir George Chetwynd and the sneak-thief-"The Mate" holds

\section{CHAPTER II}

Death of my beloved father-My inheritance-Edward William Jaquet-Fidus Achates-Our menage at Twickenham-My first real race meeting-My canine shadow-Ted and I marry two sisters; a double wedding-My first racing pony and a bad start at Hurlingham-Jesse Winfield sets me on the right track-A fine average-The peerless Catona-An Irish excursion-"Rough stuff" which misfired

\section{CHAPTER III}

"Be thou pure as ice and chaste as snow, thou shalt not escape calumny "-Etna the double of Catona-The Usher, a rusher ! An oversight leads to legal action-Lord Finlay of Nairn and Lord Russell of Killowen-The National Pony and Galloway Club-Harry de Windt-Innocence invites suspicion-Ted's tits-Virtue its own reward- "Charlie" Beresford-" Harry" Bentley-A trial and its sequel-Some conspicuous riders.

\section{CHAPTER IV}

We establish ourselves at Missenden Abbey-A scratch pack-I inaugurate the Missenden Harriers-The Belhus huntersYeoman and Melbury-A strange coincidence-I absorb the Hambleden Vale Harriers-William Snaith and the Cripps' family-The ethics of stag-hunting-The wild and the carted stag-A kill in the open-" He laughs best who laughs last !"First words about "Roddy" Owen . . . . . . 


\section{CHAPTER V}

Back to pony racing-A home meeting- "Bunny" Leigh"Gratty" Blagrave and Charlie A'Court (Col. Repington)Missenden trout : a three-pounder-A glorious evening's sport-The Misburn dries up-Chequers Court-A preposterous claim that failed-Vale! Missenden Abbey and the M. \& H.V.H.-The O.B.H. East and West-"Uncle Punch" -I am offered the Mastership of the whole country-Lord Lonsdale, a friend in need-The "Gay Gordons"- Mr. Chaplin lends me the Blankney pack . . . . .

\section{CHAPTER VI}

Cubbing-My Curraghmore bitches-Blanche, Lady Waterford"Dear old Bricket"-Tom Firr-" A bad huntsman cannot make a good pack"-Lord Chesham-A cabal-Bob WebberFishing in the Chess-The Drakes of Shardeloes-"Mr. Ekard" -A close contest . . . . . . . .

\section{CHAPTER VII}

Outlying foxes-Peter Chutterbuck-Stanmore Common-A by-day and the run of my life-Brother Irwin "gets the wind up "All my eye- "For it!"-A general meeting-Defeat of the Committee-I am too magnanimous

\section{CHAPTER VIII}

Social strictures-The O.B.H. country again divided-"Mutey" Drake-Pity the poor M.F.H.-The débâcle: Hounds and horses under the hammer-Samson and Trimmer-Rare old Landsman, an ideal hound-A forgotten tragedy . . . 100

\section{CHAPTER IX}

A rash wager- "All's well that ends well "-The huntsman hunted - Happy days at Brigstock- "Rock" and "Tony "Burghersh -A hunting tour in the shires-The Fitzwilliam and Bache Cunards- "Sugar Candy"-A duchess in embryo-The stone walls of Blankney-Another " busman's holiday "- " A pushing young particle"-Purblind and almost dislocated-Neck or nothing !. 


\section{CHAPTER $\mathrm{X}$}

The curse of versatility-My first winner under "legitimate " rulesPAGR A Chester Cup veteran-Lady Frederick-Racehorse $v$. Pony ! -Left at the post-My new colours-Enter Weasel, "the wonder worker !"-A rare bargain-Guinevere "the genuine"

\section{CHAPTER XI}

More about Weasel-My first mount on him-Misplaced gallantry — "Bonnety Bob"-Armada - "There's many a slip "-So near and yet so far-A dead heat-Class must tell- "Geoie "Gunnis and his Mongrel-Listeners hear no good of themselves-Never say die-A sensational race and a priceless protagonist" .

\section{CHAPTER XII}

The sportive double-" The Boden Eccentric "- My first ride on Latimer-The first barrel of "the double" scores an easy winLatimer, proxime accessit at Lewes-A promising hurdler comes to a sad end-A nice wager-Weasel and I opposed by the crack amateurs-A tortoise and hare race-Weasel gets home by a short head and "clicks the double" $\mathrm{A}$ hundred to one chance in a field of three scores-The fatal policy of overconfidence

\section{CHAPTER XIII}

My last ride on Weasel-The best of friends must part-Stable companions of equal prowess-Weasel and Hugger Mugger, "fifty-fifty" $-\mathrm{A}$ crack amateur in opposition-A desperate finish between four-Weasel obliges for the last time-His otium cum dignitate-The "undefeated Tommy Lushington" and hefty "Bill" Moore-Weasel's understudy-Not an armchair ride-I "ride" a Grand National and a Derby winner !I am installed at Headbourne Worthy-My fidus Achates as manager-W. H. Manser and his family-"Woggy" . . ${ }^{56}$ 


\section{CHAPTER XIV}

George Thursby makes his bow-"An unequal match" (alleged) -

Trelaske $v$. Foghorn-George fails to take revenge at "the doves "-Roscidus, "the prince of rogues," takes on St. Bede and chucks up the sponge-Another "unequal match"Trelaske $v$. the Pusher-An impertinent comment and a humorous one !

\section{CHAPTER XV}

The purchase of Dornroschen at the Doncaster sales for " a song "Gurry is contemptuous but Davis is wișe to merit-She wins when pig fat and I buy her in-An historic match and amazing wagering thereon-The Ring hilarious-Dornroschen lowers the mile time record when winning the Nottingham handicapPurchase of Blankney-A colossal steed-Blankney $v$. Macuncas- "Jimmy" Duke in the cart again . . . . . 176

\section{CHAPTER XVI}

Our little lot at Headbourne Worthy-The High Peak WelterTrelaske a stayer-Speed and stamina-The wonderful memory of the equine race : two striking examples-A fatal bolt from Heaven-Chevy Chase, amiable but unlucky-An error of judgment-I breed a winner and annex a prize for nomenclature - "Picking "em up cheap!"-My "skins" win five times their purchasing price!-I pay four figures for a filly who never wins me a brass farthing-Marcus Beresford has "not time to look!"

\section{CHAPTER XVII}

A sad disaster to Dornroschen-An official handicapper "side-slips," but I fail to take advantage-The Jockey Ring-A funny favourite "clicks"-An old head on young shoulders-Honesty rewarded and the biter bit-The dying jockey's admonition 


\section{CHAPTER XVIII}

"The Jubilee Plunger"-His love for children and dogs-A " $\mathrm{fly}$ nat"-A try out at pyramids-A side-slip and a prisonUndefeated spirit-Tod Sloan not the first "croucher"-The advantages of "the crouch" and its faults-The worst seat and the best hands-Tod demonstrates-No advocate of catgut coercion-Tod the philosopher-The pot boils over-Never "warned off," but "advised not to apply"-Tod's sun sets-A beautiful wife and a spectacular cropper-Captain Roderick Owen - The resourceful Roddy-His sad end . . . .

\section{CHAPTER XIX}

Thrilling finishes-Melton $v$. Paradox-The mighty OrmondeThe Bard-The unlucky prefix "The "-The homeric struggle between Ormonde and Minting-Ard Patrick $v$. SceptreAlsopp, Madden, Bradford, and Calder-Bradford's first mount -H.R.H. puts me wise-So does Jack Gubbins-Galtee More's super-excellence-Unbeaten horses- "The Spotted Wonder "Would he have won the Derby ?-The weak link in his hereditary chain-Isonomy and his lazy but brilliant son IsinglassThe best I have seen run-The best looking-The ugliest

\section{CHAPTER XX}

Mr. Jersey and Jeanne-A musical amanuensis-Open house at Regal Lodge-Captain Machell-A welcome "retriever"-A Very Great Personage-The perfidious Peter-Putting my foot in it -The Prince's tip-Jeddah disappoints, but pops up unexpectedly-A hundred to one winner of the Derby-Mr. Jersey's foresight-Merman makes good but Aurum misses fire-Lady Rosebery, a welcome legacy-Amberite "no gentleman !" .

\section{CHAPTER XXI}

Arthur Coventry-Blankney takes revenge-Dornroschen and I slam Blanc and Arthur- "Tommy " Lushington undefeated- "Bill " Moore, George Baird, Bobbie Fisher, and "The Child"- 
"Roddy" and "Rock"-The Earl of Dudley-"Wengy,"

Charlie Cunningham, Dan Thirlwell, and "Mr. Charles"-

Major Frank Atkinson, "one of the best"-A plethora of tips

-Humphries' day out-A colossal "win," but no cash!-A catch bet .

\section{CHAPTER XXII}

Dreams I-A very vivid one which materialized-A cryptic dream which left me guessing-The Animals' Derby-The Squirrel " home" first !-The right colours but the wrong colt!-George Fordham's only Derby triumph . . . . . . 256

\section{CHAPTER XXIII}

Jockeys of the old school-Johnny Osborne does me a service-So does Tom Cannon, senior-I patronize the apprentices and prove a mascot to them-The Chaloner and the Loates' familiesJesse Page-George Fordham "quite understands "- "I shall never get home by a nob "- "Phwat detained yez ?" . . 262

\section{CHAPTER XXIV}

Presentiments!-Cabin Boy's victory foretold-The mystery of Medora-I am warned that Persimmon is destined to beat St. Frusquin-La Flêche's downfall, not her true form-St. Simon to the rescue-End of my racing reminiscences . . . 267

\section{ENVOI}

A finger in every pie-I could not specialize-The curse of versatility-Sport and sportsmen-Field sports proper-The cant of cruelty-Falconry-A natural flight-Sparrow hawks $v$. Heron-The harried quails . . . . . . . 273 
CHASING AND RACING 



\section{CHAPTER I}

T $\mathrm{T}$ has been said that the true horseman is so born, not made, and that hereditary leanings are sure to manifest themselves during the up-bringing of the child. Every rule has 1 its exceptions to prove its efficacy; though where this same heredity fails, its forebear, atavism, may manifest itself irregularly and sporadically, missing several generations before revealing itself in some unit whose immediate parentage gave no hint of the trait in question.

So it must have been in my own case, for I came of a stock sorely afflicted with hippophobia (a word of which I hold, I should imagine, the copyright, and by which I claim to signify, "fear of horses," derived, of

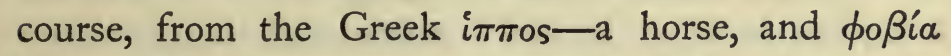
fear). That is to say, so far as bestriding the noble steed is concerned; for some of my near relatives, notably my distinguished "Dads" could handle the ribbons quite efficiently; but as for throwing a leg over one of his favourites, nothing would have induced him to court the adventure, although an occasion did arrive, when such became inevitable. This was when our late beloved King Edward was married to the "Sea 
King's Daughter." It was arranged that the Lord Lieutenant of Middlesex and his posse of DeputyLieutenants were to act as escort in the wedding procession. My excellent parent being of the cult, found himself in the awful predicament of having to venture outside one of the dreaded beasts, or to give up participation in the historical event. So he screwed up his courage and was hoisted, in all the splendour of his official garb, on to the back of a particularly amiable and plegmatic drum horse, borrowed from H.M.'s Life Guards. With a stalwart trooper to hold his (my parent's not the gee's) legs, "off" and "fore," the ordeal was successfully negotiated; but though the staid old black had not ventured out of a walk from first to last, the dear old "Dads" suffered pangs in the lumbar region for many days that supervened. When I was a nipper, there was a tradition rife among my female relatives that one of my father's brothers had been a devil of a rider. In fact, some went so far as to declare that he had been a "gentleman jockey ;" but when or where he had distinguished himself in the pig-skin, I never could discover. Anyway, he passed in his checks at an early age; his demise, so I was informed, being due to copious libations; which may have cheered, and undoubtedly did, intoxicate.

So much for my Uncle Dudley.

It was left to me to revive the tradition as far as the horse-riding part of it was concerned ; albeit I was not seized with any inordinate desire to distinguish 
myself as an equestrian of the haute école, in my early days.

My first venture, however, brought out that competitive spirit which has been an ever recurrent and abiding trait in my character.

My Cousin “Ted " Jaquet,* son of my father's sister, Harriet-better and more affectionately known as "Bunny "- -had, with his sister Alicia, been brought up in our London residence, 36, Russell Square, and consequently we were on the terms of closest friendship; though I had encumbered the earth for three years longer than he had. When lads are in their "teens" three years count and account for much. I am afraid I rather lorded it over Ted in those days, and was inclined, at times, to play the bully; but as we grew older the value of the hiatus from my point of view, gradually disappeared, until there came a day when my young relative openly defied me. I could not give away the weight (about two stone), and therefore my physical supremacy came to an untimely end.

When my father died, at the normal span of seventy years, he left me a fortune, and the implied duty of "looking after" Ted, who had then just attained his majority and had lately been bought out of the 8th Hussars, in which distinguished regiment my cousin's

* Shortly after I had written the last of these pages, Nov. I92I, death robbed me of this life-long friend, brother-in-law, and first cousin, the energetic, genial, and thoroughly efficient secretary of the Kennel Club. R.I.P.-H. C. 
adventurous spirit had constrained him to enlist. An experience by the way which, later on, served him in good stead, when he and I were sporting the gorgeous " outfit" of the Duke of Cambridge's Hussars (M.Y.C.). I now installed him Secretary of State, Agent General, Chief of the Staff, Q.M.G., Fidus Achates, and boon companion-a sort of personal Pooh Bah, in fact. Like myself, there was nothing in his pedigree which suggested horsemanship as a likely recrudescence; but assuredly he was obsessed with the desire to disport himself in this direction; though his too solid flesh forbade dreams of glory on the racecourse.

I must go back a bit to describe our first equine adventure.

In our stables at my beloved home, Moat Mount, situated on the summit of Highwood Hill-the highest point of the county of Middlesex-there were, besides Tommy and Pet, the bay and grey cobs, driven by "The Dads," a pair of " camels," whose duty it was to drag the family barouche, containing my mother, when she paid formal calls on the neighbouring "quality" (she was mostly of Irish blood, with a dash of French) or when she devoted two and a half weary hours to divine worship on the Sabbath. These ponderous " coach horses "were named respectively Castor and Pollux, and it was difficult to tell " $t$ 'other from which," either in appearance, pace and action (alike inconspicuous) or temperament. 
Came a time when "The Mums", was recruiting her health by the sad sea shore (she was a semiparalytic, poor soul, and needed these annual relaxations).

So Messrs. C. and P. were kept in the stables, eating their heads off and waxing more gross and plethoric daily.

The fact struck Ted as unreasonable, and he suggested that they should be called upon to convey our vile bodies on their broad backs. I had my qualms, not I regret to say, of conscience, but of nerves ! Having conquered my misgivings, on the noblesse oblige principle, we deliberately bribed the coachman, commandeered the noble animals, and set forth. Goodness only knows if either gee had been previously " backed," but they behaved in angelic, style. So much so, indeed, that my soul having grown stronger, I actually suggested a race on the turnpike road! Always ready for any sport, Ted agreed, and we lined up with a good straight mile of macadam in front of us. When the mutually agreed signal was given and the flag fell, Castor and Pollux " began slowly" as the sporting papers have it ; but a liberal administration of the blackthorn awakened them to their responsibilities, and they put in good work. Being evenly matched, despite the handicap of Ted's superior weight, the struggle was intense and the two-owing to their constant parallel association, with the pole of the barouche between them-kept 
religiously head to head. My primitive idea of "finishing" was to let my mount have an absolutely free rein. Under normal circumstances this would have stopped him, and given victory to Castor (Pollux was my mount), but in this case it did not affect the result, which was a dead heat; though both Ted and myself stoutly claimed a head victory, and the stakes of " one bob," which had been agreed upon.

Well, we just managed to get the poor "heavenly twins " back to the seclusion of their respective boxes, but that was about all. Needless to say that the family barouche remained silent and inert in the coachhouse for many a long day; whilst the local vet. had the time of his life.

So ended my first race, which occurred during the holidays, when I was a Harrovian.

At Cambridge I devoted myself to the river, where I had the distinction of creating a record, which so far as I can ascertain, has never been lowered.

Perhaps space will enable me to deal with my exploits in the boats later on ; but for the moment, I must " cut cackle and come to the 'osses."

I did a bit of hacking when up at Trinity; but I did not hunt, except on foot, with the college beagles. Nor did I patronize "The Grind;" but I had seen "colours," and had heard the thunder of hoofs and the crack of lethal catgut, even before I became a member of the University; to wit-when I was coaching for the Trinity Matriculation with my kind 
old god-father, Canon Harding Girdlestone, at Gloucester. His son, Theophilus, and I used to wander about exploring Nature, and sampling her gifts. One day we happened on the confines of the racecourse during the progress of a meeting, and having mounted a high bank, we had an excellent view of the proceedings, as far as the back-stretch was concerned ; though the stands and winning post were remote from our eyes. But my blood was fired. I did not know the names of the horses, nor of the jockeys, nor whose colours they wore; but I waxed excited as the fields swept by - the riders shouting and cursing, and the dust flying! "Theo" was bored to tears, but I was spell-bound. Only once when I was "up" at Cambridge did I attend a race-meeting, cap-à-pie-my first experience. This was a jump affair at Aylesbury, whither I had been escorted by some of my more sporting Varsity pals. My impressions of this adventure are somewhat vague. The "sticks" and "flags" never appealed to me as did, and do, flatracing; but I remember on this occasion being relieved of my silver watch, which, strange to say, illustrates an incident that stands alone. Despite my long experience of race-courses of all sorts and sizes this was the only occasion on which my person or my property has been interfered with.

$\dot{A}$ propos. This may be counted an opportunity for the interpolation of a couple of yarns, which may perhaps be accorded a leaven of humour. 
The late Sir George Chetwynd had been presented with a scarf pin by some admirer or admirers, the sentimental worth of which exceeded its intrinsic value; but it disappeared from its satin sanctuary one fine day at Ascot. Its owner waxed wroth, and as he was acquainted with a certain doyen of the "boys," he sought out that worthy and complained bitterly that he, as an owner, should be subjected to such illegitimate pilfering.

"All right, Sir George," protested the "head." "It's all a mistake of some blithering novice of ours. I'll see you gets it back all right. Go over to ver firs on ver far side, at the long interval, and yer pin will be 'anded back to yer-see! But you'll 'ave ter come acrost wiv' a couple of thick 'uns, jest ter show there's no blinkin' animosity."

And so it turned out : the Sporting Baronet retrieved his beloved pin, and the chap who handed it over received the stipulated honorarium.

Later on, Sir George, having an early engagement in town, decided to miss the last race and to take his place in the first waiting train. Comfortably ensconced, and enjoying a contemplative weed, he became aware of a respectably dressed little chap, who might have been a methodist preacher or an undertaker on the loose. He kept perambulating past the carriage, and peering at its occupant. At last he paused and gave tongue. 
“Beggy pardin, Gov'nor. Might you 'appen to be Sir George Chetwynd?"

The answer was in the affirmative, with the addition of the reasonable query, "What can I do for you ?"

"Well it's this way," began the interloper; "you 'ad a pin pinched on the course didn't yer ?"

The listener assented, but assured his questioner that the gaud had been recovered, and that everything in the garden was lovely!

But the baronet was beset by a further " interrogatory."

"That's all right, Guv'nor, but would you mind tellin' me, in strict confidence, 'ow much you bunged over to the bloke wot 'anded you yer property?"

"Well, I don't know how it concerns you mi' lad," responded Sir George ; " but if it is of vital importance that you should be acquainted with the exact sum that passed, I don't mind confiding to you, that it was two pounds sterling."

" Blyme! a couple o' quid! 'Ark at that now ! So 'elp me Gawd, they only gave me 'arf a thick un, and I was the guy wot pinched it orf yer !"

A gang of roughs once had the temerity to attempt to turn Sir George Astley (affectionately known as "The Mate") upside down, and to shake all he carried out of his pockets; but they caught a tartar. The genial and breezy baronet was no mean performer with " the raw 'uns," and after he had neatly laid out 
three of the crowd, the rest suddenly remembered that they had an important engagement elsewhere, and so took to their heels, raising a miniature sand storm, which completely concealed their retreating forms. These cowardly rascals have been the curse of the turf from time immemorial, and so far from their activities having been diminished as time goes on, they grow bolder, and even more brutal than of yore. The railway authorities and the police seem to be quite unable to cope with the crooks; though all are identified.

I suppose there is some truth in the adage which ascribes honour to thieves. Among these ruffians there is one law which is pretty strictly observed. No owner, trainer or jockey is to be robbed : for it is recognized that through these, racing exists. If there were no race-courses one of the most prolific fields of enterprise would be closed to the activities of the "Boys."

On one occasion, at a little meeting at Buntingford, the promoters had neglected to call in the aid of the police, thinking that their venue would not be deemed worthy of attention by these same "Boys." It was patronized by all the "toffs" of the county, who flocked to the course from far and near, in four-in-hands, tandems, and other sporting conveyances; bringing with them their womenkind, bedizened with a blaze of jewellery. The family plate was conspicuous, and when the luncheon interval arrived, at a given signal, 
an attack was pressed home by the roughs. After having filled the silver bowls with the choicest vintages of their unwilling hosts, their health was drunk with acclamation to the very dregs, and then the trophies, plus forks, spoons, and other utensils of sterling metal, were transferred to convenient sacks and dispatched to some melting furnace, the situation of which was more than problematical. Moreover, the ladies were urgently pressed to bestow souvenirs in the shape of diamonds and other precious stones on their husky "guests" and none dared to refuse. After that, the gang devoted themselves to the real business of the day-viz. racing. The few "bookies" present were freely patronized, but the punters took no risks. They chose their own favourite and made sure of its " clicking " by the simple expedient of sending patrols to all the fences, to stop any horse and rider (except their own choice) who seemed to have the remotest chance of landing the stakes. They did pretty well at this, but decided that the pencillers ought not to be allowed to depart with any superfluous dross remaining over-after the aforesaid operationsand acted accordingly. To illuminate the end of a perfect day the exuberant "lads" set fire to all the fences and stands, and departed, drunken, but happy in a blaze of glory.

Hark back ! 


\section{CHAPTER II}

7 HE night came when, on entering my dear old dad's study, I found him dead in his chair. He had never had a day's serious illness in his life, and had always prayed that his end might be sudden.

His prayer was heard !

"His life was beautiful," I cried,

"As he has lived, so has he died."

It was a terrible shock, which threw me into a state of neurasthenia for the time being. We had been such pals and had always seen eye to eye in regarding the forces and necessities of Nature, which, despite man's fatuous endeavours, must remain unalterable and implacable to all eternity.

My father was a just man, and had little respect for the hard and fast rule of primogeniture. Consequently his considerable fortune was equally divided between my half-brother, Irwin, my sister Ada (Mrs. Bennett-Edwards), and myself; but we were to be life beneficiaries only-with remainder to our respective offspring in esse and in posse. At that time, mine were in posse; but Irwin's hardly likewise, as 
he had been married for nearly twenty years, without issue, and his wife was, poor soul, a hopeless invalid. But my sister had a quiver-full.

Just before we lost our dear old "Dads," I had become engaged to Ted Jaquet's sister, my first cousin, Alicia ; but "The Mums" did not approve of consanguineous marriages, so the romance failed to materialize. Consequently I was fancy free when, having handled some of my inheritance " on account," I took a furnished house in Kensington, which Ted and I made our H.Q. what time we were running around. We brought back a pair of goats from the Emerald Isle and turned them loose in the garden attached to Cleeve Lodge, where they proceeded to play such havoc that I had to disburse $£ 250$ when my tenancy came to an end !

Then I had leanings toward a strictly rural life and so secured a furnished abode at Twickenham, where Ted and I were to live-surrounded by live stock-as confirmed bachelors. We had dogs galore (with one Charlie Heritage as kennelman), cats, rabbits, a surly and savage badger, geese, turkeys, poultry of various breeds, and small deer in the shape of aviary pets, guinea pigs, white rats, and tortoises.

But even with this miniature farmyard and zoo combined we were restless. We had entered into possession in the merry month of May. The call of springtide stirred our blood and turned our fancies (by no means "lightly") be it said, to thoughts 
of love. Local beauty offered no opportunity for the chase. We were constantly driving up to town in our dogcart, with its smart trotter, Phœbe, in search of adventure, to the great neglect of our menagerie.

At odd times, however, we did indulge in desultory hacking in Richmond Park, on hired gees. It was inevitable that we should do a bit of private racing on the inviting stretches, with the result that, on one memorable occasion, my mount "ran out," and took me unwillingly through a clump of trees, where, had I not ducked in the nick of time, a low-growing branch would have assuredly deprived me of my "napper," and there would have been an end of all my " reminiscences." By what close margins does Kismet keep on its implacable course !

It was whilst residing at Cambridge House, Twickenham, that I had my first experience of a real live race-meeting. This was the Epsom First Spring, to which Ted and I hacked over on the day when Bend Or triumphed in the City and Suburban of $188 \mathrm{r}$. He beat Foxhall cleverly, conceding a lump of weight. When the latter's extraordinary performances in the Cesarewitch and Cambridgeshire * in the following autumn are considered, it will be realized what a smasher was the chestnut son of Doncaster. He needed to be that, the previous year, when on the same classic downs he just, but only just,

* Foxhall carried 7 stone $6 \mathrm{lbs}$. in the Cesarewitch and 9 stone in the Cambridgeshire. 
succeeded in putting paid to the high pretensions of Robert the Devil in the Derby of 1880 . Some say that inferior jockeyship was alone responsible for the defeat of the latter, and prophesied that when the Leger came round, Messrs. Brewer's champion would have an ample revenge. This forecast, as history relates, was borne out to the letter : but personally, I have always believed that at Doncaster, the Boy in Yellow was a bit off colour ; whilst Robert was top notch, as he proved when he added the Cesarewitch to his laurels.*

All this, by the way!

Ted and I had backed the Duke of Westminster's champion all right enough, but no material gain came our way. We had remained on the far side of the course in a small enclosure near the winning post, and had selected one, Cox, as a likely penciller, probably because he shared my patronymic; but when it came to claiming winnings, his too solid flesh had melted. In vulgar parlance, he had " done a guy." So we jogged back to our celibate abode certainly sadder, if not wiser, lads.

It was during our sojourn in Twickenham that I suffered a loss which caused me dire distress. I have been, from my earliest days, more of a "cynophilist," than an "hippophilist." Though forming attachments to various units of the equine race, I generally regarded

* After winning the St. Leger, Robert the Devil was successful in the Cesarewitch, carrying 8 stone 6 lbs. 
them as a means to an end ; whereas my own particular canine pals claimed a place even nearer to my heart than some of the indispensable females of the human race, who from time to time, claimed my temporary allegiance. Of all my familiars none has been dearer than a certain fox-terrier registered as Coxswain, but known to me and my friends as Cockie. It was from this little chap that I derived my own sobriquet. A fair friend had declared that I and my canine attendant were strangely alike, not only in appearance, but also as regards temperament, and that, therefore, it behoved all and sundry to address us by the same name. As my terrier was a particularly handsome specimen of his breed I raised no objection on the grounds of personal appearance; but when it came to a question of character, I was inclined to demur, for my tyke was a rascal of the deepest dye, and possessed of a cayenne pepper temper which brooked no interference by any one except his master. He was absolutely fearless of God, man, devil, or the creatures of the wild, including the harmless, necessary cat, against which he waged eternal warfare. Here was a striking example of hereditary temperament for his sire, Mr. Skinner's "General," was a holy terror and when visited by the opposite sex, for the purposes of eugenic propagation, it was always a tossup whether he would proceed to amorous gymnastics, or would elect to tear the windpipe out of his would-be inamorata. Cockie's dam was the darling of 
Ted's heart-Stella, by name, sprung directly from the primitive Nottingham strain, being by Old Sam, ex Cottingham Nettle.

My favourite had the run of the premises and was the terror of all interlopers. I had taught him to be a dog of all works. He was as keen as mustard on fur and feather, and did duty for spaniel, pointer or retriever; though as regards the last-named industry, I always had to race to the kill; for Cockie was decidedly of iron jaw, and would reduce a partridge to a mélange of blood and plumage in an incredibly short space of time.

The sad day arrived when, returning from a cutting-out expedition to the Metropolis, there was no little pal to greet me with his usual demonstrations of joy. Cockie had disappeared, utterly and irretrievably. Rewards of $£ 5, £_{1} 0$, and finally $£^{2} 5$, elicited no response. I put a detective on the track of possible dog-stealers. He followed what he deemed to be a slender clue into the purlieus of the East, where he was so heavily drugged that he died within a week. Thus tragedy trod on the track of tragedy.

Cockie had passed; but his name survived; for as "Cockie" I have ever since been known to my intimates and to the sporting public in general.

Strange to relate, friend Ted had suffered the loss of Cockie's dam, under similar circumstances. He and I were strolling in the grounds of my old home, 
Moat Mount, accompanied by the little old bitch. Presently she was missing. From that day to this her fate and what led to it has been a complete mystery. Truly coincidence has a long arm.

As the days passed we two inseparable young bachelors became more and more fed up with our ménage and our polyglot menagerie. Our visits to town became of daily occurrence. Both of us had leanings to the sock and buskin; in my case another example of direct heredity, for The Dads was one of the best amateur actors, reciters, and readers whom I ever remember to have seen or heard. So we joined the Philothespian Dramatic Club. Whilst fretting our hour before the footlights we made the acquaintance of two fascinating sisters, with the result that we soon found ourselves "engaged." One fine day in October, I88I, our father-in-law elect was seen proudly descending the aisle of St. James's, Piccadilly, with a radiant daughter on each arm. Ted, having doped himself with libations of champagne to calm his nerves, was in peril of selecting my bride, instead of his own liege lady; but the latter promptly put him right and all went well.

To start domestic life in earnest I secured a maisonette in S. Audley Street, and by way of diversion, joined Hurlingham, the Gun and (later) the Ranelagh clubs, with a view to exploiting my skill as a pigeonshot. It was at the first-named fashionable resort that my attention was drawn to the pony races which 
periodically took place. My imagination was fired, and I made up my mind to butt in. At Tattersall's I picked up a likely looking brown pony called Phyllis, about fourteen hands. After giving her a few surreptitious gallops in the early hours, on the Rotten Row tan, where a friendly minion of the law had discreetly looked the other way, I entered her for a members' race at Hurlingham and ordered my colours-cream, dark blue and gold hooped sleeves, quartered cap. The great day arrived, and as I weighed out I had a sharp experience of that distressing sensation, "the needle." There were seven runners on the cramped course, and in my anxiety to be well away I slightly broke the line. "Go back a bit, Cox"this from the starter. Of course he meant "pull back" ; but in my "greenness" I turned my mount "about," and as the flag fell I was left some two lengths and there remained; but Phyllis and I negotiated the sharp turns quite comfortably and I kept my seat all right. On a subsequent occasion I was off the mark promptly and was well placed to win if my mount had been good enough ; but she was not! Although I won some nice races with her at local meetings later on, her form was not up to the Hurlingham standard. Something a deal smarter had to be found. It was at this juncture that I came in contact with Jesse Winfield. I believe he was looked upon as very hot stuff indeed; but all I can say is that he played the game in a perfectly straightforward 
manner with me. He found me some exceedingly smart material and trained it to perfection; so that I had a real good innings and showed a remarkable riding average for several successive years. The best record, twenty-one mounts, thirteen firsts, three seconds, two thirds, and only three unplaced! My initial bargain with Jesse resulted in the purchase, at a quite reasonable figure, of the peerless Catona a b.f. 4 yrs. by Soapstone (son of the great Touchstone)-Calm, by Orest, by West Australian. She went easily under the 14.2 galloway standard, and was a bloodlike, varminty sort, with beautiful manners. The first time I rode her at exercise she was bitted with a double ring snaffle, but she yawed and stretched at it, pulling harder than was comfortable. Jesse suggested that as I had "hands" it would be as well to try a "Hanoverian." Sure enough the little lady took kindly enough to the formidable restrainer. Her début was at Ranelagh, and here I practised tactics which I have since found most effective, not only in pony racing, but later on when engaged in the "legitimate" line. I jumped off smartly, and made the running until my mount was going evenly in her stride. Then I gradually held her back until she lay about fourth ; but without losing place on the rails. Approaching the final bend I let her go up to the leaders, and in the straight, came away to win easily by a couple of lengths. My first win and a delightful ride. A thing not easily to be forgotten. While I 
am about it I may as well run over the remarkable career of this champion "pony." At Ranelagh and Hurlingham she became an institution-a sort of fashionable idol. She was as good over the sticks and between flags as she was on the flat. In "jump" races I confided her handling to my friend Harry Bentley, a most accomplished horseman, a crack shot, and withal a man of brains and literary accomplishments. He won on her at every time of asking. On one occasion this slip of a thoroughbred carried no less than fourteen stone ten pounds over the miniature Ranelagh Steeplechase Course (two miles) and won in a canter.

After having ridden her myself to victory eleven times without ever having to ask her to pull out anything extra in order to slam her fields, she at length broke down. Winfield spared no pains to restore her once more to racing trim, and at last imagined that she was sound again. She was saddled at Ranelagh, and at one time it looked as if the monotony of her triumphs was to be maintained; but when entering the straight, and making her usual effortless but remorseless run, she suddenly faltered and nearly fell. She hobbled in, a hopeless cripple and never ran again. Meanwhile I had exploited her in the provinces far and wide, and everywhere successfully.

One day Jesse came to me wearing a mysterious expression. "Squire," he said, "isn't it time we got 
some good dough out of Catona. Running her with 4-I laid on her, cuts no ice and don't pay for her keep." "There is an open race at Cork with $f_{200}$ added money, worth goin' for, eh? and perhaps, a S.P. job, that will figure out at 100-8. What about it?"

"It's a long way to go," I ventured; "though as you say, $£ 200$ of the best is not to be sneezed at. But as for getting 100-8 or any sort of reasonable odds S.P. I take leave to disbelieve you altogether. Why her fame is as well-known in Paddyland as it is here !"

"Ah, that's where the laugh comes in. She can be entered in any name and so disguised that even you would not recognize her."

"Jesse," I exclaimed with frigidity, " you ought to know me by now. What reason have I ever given you to suppose that I would indulge in any sort of crooked work?",

"You misunderstand me, Squire, there is nothing crooked in this deal. The race is open to all ponies and galloways under I 4.2 There is no question of registration, declaration, or ownership. Any name can be selected, and the handicapping is on the weight for inches principle. In Ireland they change the names of their ponies every time they run."

"Well, as long as we do not contravene such rules as may exist, I don't mind having a dart. Get a move on !"

In due time the entries for The Great Shamrock Pony Race at Cork appeared-a formidable list of 
"Paddies," “Leprechauns," “Fenians," “Dan' O'Connells," "St. Patricks," “ Mollies," " Norahs," and "Colleens."

Amongst them "Mr. Gilhooly's Fly" (none other than the great Catona, if you please).

Passing over preliminaries, let us look at Fly in the paddock. Ye gods, was there ever such a transformation? It seemed incredible that the mean, broken-coated screw, looking as if she had been dragged backward by the tail through a horsepond, was in fact my bonnie brown Catona. Yet here she was in the flesh, with a dirty sack thrown over her, by way of a loin cloth. And the "colours" which Jesse had provided! A dirty white flannel jacket, and an equally disreputable slate grey cap. There were twenty-two runners of all shapes and sizes; with alleged jockeys of doubtful standing. Not one of whom had the remotest intention of observing the laws of racing, written or implied. There was to be no pulling back and waiting to come with one run this time. Success depended on a flying start and going hell for leather, from pillar to post. But it came off all right, and "Fly" won easily enough.

Jesse and Ted between them had been hard at it trying to work a S.P. commission all over the United Kingdom, but it was no easy job, I can assure you.

Elated at the result, we eagerly awaited the price. We had not a bet in the local ring, but as we heard 
'undred ter wan! "others" shouted, persistently, we had beatific visions of colossal gains.

Next morning The Sportsman reported the race and gave the S.P. return as evens, Fly; IO-I, Murphy, Leprechaun, Kathleen Mavourneen ; I00-8, St. Patrick, Shillelagh; 20-I, others.

Evens, Fly! The gaff had been blown and our S.P. commissions, which amounted in all to $£^{6} 3$ only, had come across the Irish Channel, and made our transmogrified champion a raging favourite. You should have seen Jesse's face, it was a study in disgruntlement !

Well, it served me right! We had contravened no rules; but the whole transaction was an unsavoury one and an insult to the reputation and prowess of Catona. Anyway, it taught me a lesson and recalled the good old adage which recites that one cannot touch pitch without being defiled.

In those days there was a superfluity of " rough stuff " handed out to such as went to the starting-post on "ponies." Some of the "courses" on which we disported ourselves were of a very cramped and circumscribed character. The turns were so acute that one had to swing around at an angle of forty-five degrees or less, and the turf over which we galloped was often of the roughest and most holey description ; consequently accidents were of frequent occurrence (though only on one occasion, did I witness a fatal issue). At any rate we had to learn how to 
handle a rampaging little "blood 'un," called by courtesy a "pony" under all sorts of trying conditions.

Another miscalculation of chances from a financial point of view befell me when I took Catona to compete for a special $£_{\mathrm{I}} \mathrm{oo}$ cup at Aylesbury.

I knew that it would be almost impossible to back her; so bethought me of another scheme by which I could inflate my banking account.

Among the most enthusiastic followers of my hounds (the O.B.H.) was George Gurney, a wellknown, and greatly respected operator in the Silver Ring. A true sportsman and one of Nature's Gentlemen.

I knew that he intended business at the meeting in question ; so after kennelling my hounds one afternoon I called upon him at his home on Croxley Green. He opened fire with : "Well, Squire, I suppose you will win that Aylesbury affair on your little mare won't you ?"

"Probably-bar accidents."

"Are you going to back her?"

"No chance, George, unless the opposition is much stronger than it appears. Look here, what if I stand in with you and Catona runs for the book? I should imagine that some of the other owners and the public will support the field."

"Right you are, Guv'nor; but I have my doubts. They will all want to have a bit for askin' on yours!" 
There were, if I remember rightly, some fifteen starters for the race, and just as I had weighed out, Jack Westrup, runner to my hounds, came up and " bit my ear" as the saying goes.

"Sir," he whispered, "I've just overheard Mr. and $\mathrm{Mr}$. - (naming two prominent riders) plotting to put you over the rails; so I've hurried over to give you a word of warning."

This was cheery news indeed. I could rely on Jack. Originally he had been butler to the great and popular "Dizzy" at Hughenden. He had attached himself to me when I had instituted the Missenden Harriers and taken over the Hambleden Vale pack. What he did not know about the wiles and habits of the timid hare was not worth knowing and he could always spot the quarry in her form, and whistle us for the find. Later on, when I substituted the canary of the O.B.E. for the green of the "Jelly dogs," Jack proved of inestimable service as " runner."

And now how to outwit the scoundrels who deliberately intended to risk murder or mutilation in pursuit of their petty profits?

I am not sure about the starter; but I think it was Harry Custance. It was a circular course, one and a half times round for the mile (the distance prescribed). I had drawn the inside, and perceived that the plotters were on my whip hand. As soon as we had lined up, I touched Catona with the spur. This unaccustomed administration caused her to 
jump forward nervously. "Look out," I cried, "this mare will kick you into the middle of next week if you crowd on her!"

"Here, come over on the outside, Captain Cox," called the starter. I lost no time in obeying the order.

"If there is a false start," I told him, "this mare will get away with me."

"All right, I'll see to that. Now! Are you ready? Then-Go!"

Catona was on her toes and off like a swallow, I made a bee line for the first turn, got there with a lead of a good two lengths, and stayed to win by just as far as I chose. In the dressing-room, after weighing in, I determined to let one, at least, of the conspirators know that I was cognisant of their amiable intentions.

"What about putting me over the rails?" I asked.

“ Nothin' doin' old Sport! My tit couldn't go fast enough to bite your mare's tail, much less give me a chance to barge in on her flank."

Then I went to George Gurney to see how our book had planned out. He showed me.

Some venturesome gambler had taken $5^{-I}$ in half-crowns about a pony called "Royal Oak" numbered amongst the "also ran."

The rest of the column was blank!

Thus do :

"The best laid schemes of mice and men Gang aft agley!" 


\section{CHAPTER III}

$\mathrm{H}$

AVE I ever been " invited to explain, etc" ? Why, yes! On three occasions! Each time I emerged triumphant and left the "Court of Enquiry" without a stain on my character. This, be it said, in connection with "the ponies" only. Perhaps I may be permitted to add that, as regards racing under Jockey Club and National Hunt Rules, never once was a complaint made against me; nor was any winner I rode ever objected to. As a member of Hurlingham and Ranelagh, when riding ponies at these fashionable clubs, it was taken for granted that I was far above any sort of suspicion; but in "the provinces" it was different. Undoubtedly a lot of questionable, not to say crooked, tricks were resorted to by those who considered themselves hyper-smart, and who, glorying in their misdeeds, thought that all others, including myself, were tarred with the same brush. It was, in fact, as a general rule, a case of each for himself and the devil take the hindermost. The three following examples will show with what unworthy suspicion the straightest of sportsmen and gentlemen are often regarded by those who have no claim to either title, 
but who are constantly looking for crookedness where none exists.

Shortly after I had the good fortune to become the owner of Catona, Jesse Winfield procured for me a useful filly called Etna. This one was not up sides with the champion, who was in a class by herself; but she was decidedly useful and would always give a good account of herself when opposed to any but the top-notch flyers at the game. Now Catona and Etna were extraordinarily like one another. Each measured exactly $\mathrm{I} 4.2$ and were of the same build and type. The latter was slightly brighter in coat and had a small snip of white on the forehead which Catona lacked; but seeing them at exercise together it was difficult to tell t'other from which.

A rather attractive programme had been issued for a meeting at Pontypool. The principal event offered a good chance for Catona to add to her collection of laurels, whilst there was a race for galloways that had not won more than a stipulated aggregate of $£_{s} s . d$. and for which Etna was eligible. So we determined to exploit both mares. The two races were on succeeding days, and after Catona had astonished the natives in her usual effortless manner, she was sent home. The next day Etna duly obliged, and we returned home puffed up with pride, joy, and satisfaction.

But what was my astonishment when, a few days later, I received an intimation from the Clerk of the 
Course that stakes would be withheld since I had had the effrontery to run Catona, on the second day, under a different name, in a race for which she was not eligible to compete! Of course I was greatly tickled by this "howler," but there was no end of a pother before I could clear up the stupid blunder; in fact we had to produce both mares and evidence of Catona's return to stables on the evening of the first day, ere the Stewards caved in, apologized, and paid stakes, plus my " expenses"!

The next item was staged at Portsmouth where a so-called "big" event with $\oint_{1} 00$ added had been advertised. I was very anxious to have a cut in at this, but alas-Catona had retired from the racecourse and my others were hardly good enough. So once more Jesse had instructions to find "the goods." He was not long in doing so, and reported that he had secured a miniature racehorse which had sported Captain Machell's colours under Jockey Club rules, named Kismet, by the Derby winner, KisberAngelina by Hermit. $\mathrm{He}$ was a perfect picture, but a hot-headed little devil and a determined and hard-mouthed puller. I had no opportunity of riding him at exercise and so getting on pleasant terms with him ; consequently, at the urgent prayers of Winfield and other stable connections, I turned the mount over to Tommy Aldridge, a very efficient understudy. It was a big field, but Tommy soon had its measure and won cleverly by a length. Now, not long prior 
to this meeting, "The National Pony and Galloway Club" had been formed with Captain "Freddy" Herbert as Secretary, whilst I was elected a Steward. The aim of the Association was to make pony racing a game for gentlemen to play at, wherever, and under whatever conditions, a meeting might be held. The rules were drafted on the model of those of the Jockey Club and the National Hunt, and it was thought that a clean sweep would be made of the rascality and double crossing which had hitherto thrown discredit on the sport, and that many young officers and others, who could not afford to go in for "legitimate" race riding, would be eager to avail themselves of this sport, which at any rate offered a valuable apprenticeship to more serious endeavours on the turf. Again I suffered the indignity of being accused of fraudulent entry; for an objection to The Usher (as I had renamed Kismet) was lodged on the ground that the winner was not my property. I appeared before my fellow stewards and stated how the galloway had been procured for me by Jesse Winfield. I was asked to produce the counterfoil of the cheque handed to my trainer in payment and his receipt for the same. This I could not do for the simple reason that I had a running account with Winfield and never paid him cash down for any several item. Luckily Jesse was handy with this account, showing, on the debit side, the date and the exact figure paid by him for the purchase of Kismet on my account. So that was that ! 
The third act was again laid at Portsmouth, and again The Usher, directly and indirectly, involved me in trouble. He was top weight in a handicap, which was the principal event of the day; but by this time I was training my own bloodstock with Ted Jaquet as manager and one, Bill Davies, a hot-headed Welshman as head lad. The Usher was on his worst behaviour, and kept breaking away until my arms and wrists were numbed. At last we were off, but his weight and the capers the little brute had been cutting at the post had taken as much steel out of him as they had out of his rider ; consequently, by the time we had covered five furlongs (it was a mile race) he was stone cold, and finally was cantering in with the crowd, when an inebriated marine gave him a cut on the quarters with his cane; whereupon The Usher, having recovered his wind, caught hold of his bit and bolted for the paddock. I was quite powerless to hold him! Three times he raced round the enclosure and then dashed on to the lawn, in front of the grand stand. On reaching the iron rails dividing the lawn from the course, he stuck his toes in suddenly, and I was deposited on the top of bookie Treherne, conspicuous by his luxuriant face fungus, otherwise beard. The worthy penciller broke my fall without suffering much damage, so I escaped unscathed, but a bit shaken.

I had entered in the last race of the day, a roan three-year-old colt named Epsom Embrocation, his 
sponsor being the worthy Jesse-whose marvellous embrocation it was hoped would be boomed by the exploits of the animal who, like The Usher, had been "a regular" under the name of The Stick. Incidentally I may mention that he was the laziest bit of horseflesh I ever rode. Nothing but a dog whip, neatly curled around his loins, would rouse him to a realization of his responsibilities; but when he knew that the tawse was in my hands he performed great deeds of valour, for he could stay till the cows came home, and had a nice turn of speed when he once made up his mind to exploit it. He went to sleep the first time I rode him, and only woke up in time to finish a length behind the winner. But never again ; for, without exception, after a dose of the medicine (not dope) described, he managed to carry me to victory on every subsequent occasion that I rode him.

It was this joker that was entered in the last race on the card. I had every intention of riding him myself, but I was rather shaken by my Usher adventure; moreover, I was anxious to get back to town, so I requisitioned the ever-ready Tommy Aldridge to don my colours and weigh out. I watched the race from the station approach and had the not unmixed satisfaction of seeing Tommy land the phlegmatic Embrocation an easy winner. Naturally I regretted having missed a "cushy" winning mount!

An objection came along. The grounds thereof were that Aldridge, being a professional jockey, was 
not entitled to ride, as the conditions stated that the race was for gentlemen riders only. Sure enough I had made a fatal error this time. In the hurry and confusion I had overlooked this stipulation. Of course I offered no opposition to my galloway's disqualification, simply stating the facts and admitting a moderate measure of carelessness, which, under the circumstances, I suggested might be excused. Thus, thought I, the matter ends. But not a bit of it ! Listen to the sequel! Such an eminently respectable, if somewhat dull, paper as Land and Water was at that time, had the impudence to state that I had put Aldridge up knowing that my colt would be disqualified, and that I had backed him heavily " first past the post"!

Naturally such an outrageous statement called for immediate action, and a writ was issued against the offending paper.

I briefed Sir Robert Findlay, afterwards Lord Chancellor; whilst Land and Water was represented by my friend Sir Charles Russell (who, coincidentally, became in due course Lord Chief Justice under the title of Lord Russell of Killowen). Just before the case was called, Sir Charles greeted me, and we began discussing some racing matter or other. All of a sudden he pulled up, exclaiming: "Here, I say, Cox, why, you are the plaintiff in this libel action and I am for the defendants. Go away-go away quickly!

Well, the case was never presented to the jury. 
The libellous paper offered a humble apology and undertook to publish the same, and to pay my costs. They got off cheaply I think !

$\dot{A}$ propos this question of professional jockeys, I regret to say that it was the direct cause of the débâcle of the N.P. and G. Club. During my absence from town, a meeting was held at which it was decided that professional jockeys should be allowed to ride at meetings held under the rules of the club; thus at one stroke the whole aim and endeavour of the original promoters was rendered abortive. Not only was it obvious that an undesirable type of professional would monopolize the weighing-room, but that the class of young aspirants to race-riding fame whom we hoped would be interested in and support the sport, would inevitably be choked off. And so it proved; for instead of pony racing being lifted to something like a respectable level, it became more and more decadent. The N.P. and G. Club ceased to exist, and there seems no likelihood that the sport will ever be revived, except in irregular and sporadic fashion. If on the three occasions quoted I was unjustly suspected of crooked dealing, I can recall one where appearances were so black that had a complaint been lodged, I should have had but a lame defence; though, needless to say, I and the other concerned were as innocent as babes unborn. As in after days on the legitimate turf, so in pony racing, I was very keen on matching my ponies against others belonging to friendly rivals. Among 
the latter was Harry de Windt, the distinguished traveller and author, brother to the White Ranee Brooke of Sarawak. At one time de Windt owned a mare called Umbrella, who would have been a worthy opponent for Catona had they been contemporary, which they were not. I have mentioned my first pony, Phyllis ; she was a first rate trapper, and could gallop above a bit. Harry had a similar " tit" about the same cut and height, so we fixed up a match for a "pony" which came off at Gloucester, where a particularly serpentine course had been-I was going to say, prepared-but, well, the preparation was of a most primitive order. Incidentally, I may say that, being anxious to give a sporting young friend a winning mount, I actually put him up on Catona in the chief event, with the result that the mare slipped up at one of the "impossible" turns. Luckily neither horse nor rider was hurt, though the latter, like John Jones of Covent Garden, "didn't know where he were" for quite half an hour. All he could say was : "Where's the luncheon basket?"

But about this match. It was "three times round the frying pan and once up the handle" for the mile. We negotiated the first event quite serenely, keeping close together, but the second time round, Rosalie, as de Windt's mount was named, suddenly " ran out," and went bird nesting in an adjacent coppice; so all I had to do was to jog along at my own sweet will and so earn easy money. 


\section{CHASING AND RACING}

Phyllis was as handy as you make 'em; but lo and behold, when negotiating the final round, and whilst I was complacently regarding my boots, out she went at the very spot where Rosalie had "done a guy." Harry, meanwhile, was walking his recalcitrant little jade back to that which was by courtesy called a paddock; but seeing what had befallen me, came back at a hand gallop, and slipped round the course to complete the mile. I soon had Phyllis back and in pursuit, but never could get within striking distance of my opponent. Nobody said anything, but they looked unutterable things. Well they "had reason" as our French friends say; for the show was one which asked for criticism of a not too kindly nature. Anyway I lost my "pony" (not Phyllis, bad 'cess to her), and was lucky not to lose my reputation as a dead straight rider for good and all.

On one occasion I was riding a three-yearold pony of my own breeding which had not been tried, and whose back I had never previously bestridden. As I was going to the post, a bunch of the "Boys," stood in my way and I had to pull up. I was thus addressed by their spokesman :

“'Look 'ere, Mister blinkin' 'Ardin' Cox, the Boys 'ave all backed yer, and if yer gets up ter any of yer pullin' gimes, inter 'ver 'orse pond yer goes, and don't yer fergit it!"

Here was a nice look out, seeing that I had not 
the remotest idea as to whether I should win or be down the course. As matters turned out I was a bad third. Did I pull up on passing the winning post ? Not on your life! I did not stop until I was safe inside the paddock, and when I left its precincts it was in the company of a couple of promising heavyweights of N.S.C. fame! Nothing doing for the "Boys"!

I have already explained how my cousin and brother-in-law, Ted Jaquet played Pythias to my Damon. Whenever I set to work making a sporting pie (no matter what the ingredients), the lusty Ted was sure to have a finger in it ; therefore, it followed that during the period when I was engaged in pony racing, he became seized or possessed of two gallant but rather dickey animals with which to enrich our string. Futhermore, it now was necessary for him to register his colours, Black jacket, Gold fleur de lys, back and front, Gold cap. A very chaste and striking design! which I was quite proud to don on the bigger of my pal's crocks, Winkelman, to wit, a hardbitten old fiddle-headed brown, whom long and painful experience had taught all there was to know about the game to which he was allocated. His understandings and joints were more or less callous, but if the ground was extra hard he signified his disapproval by refusing to gallop a yard. As for "punishment" he seemed to possess a pachydermatous hide utterly impervious to the most strenuous 
application of catgut or steel. Even the Embrocation's private and most particular dog whip was despised by this old sinner. But when conditions were favourable and he felt in the mood he could hop it to a merry tune, and could stick it out if pressed. I won on him first time out, and then there came a day when, in order to support a certain meeting, we entered the whole string. At that time the lazy but useful Epsom Embrocation was the bright particular star of the stable ; but in order to have something to make running for him in the principal event Ted entered Winkelman. All the stable money was on the roan, but the galloways being in different ownership, of course, no declaration could be made. There was a matter of seven pounds between the two in Winkelman's favour, and as the going was on the soft side, we figured that the old chap would condescend to carry out his mission, as in duty bound; but we little reckoned to what a disastrous purpose. Of course I was up on my own, whilst the faithful Tommy Aldridge had the mount on Ted's representative with orders to jump off and keep in front until I was prepared to take up the running. There were five other runners with whose form I was not acquainted, but judging from a paddock inspection we came to the conclusion that we commanded the situation. And so it proved, but not quite in the fashion anticipated. Tommy followed his instructions to the letter and I lay up sides with him. It was a 
mile race and by the time we had gone six furlongs the rest of the field was stone cold and Tommy and I were out by ourselves. Nearing the final bend I came up to the leader when Tommy turned his head :

"I say, Guv'nor," he exclaimed, " this old blighter is full of running, what am I to do?"

"Why, damn you," I cried, "go on and win, if you can!"

All up the straight we ran, neck and neck. Winkelman was galloping with diabolical and unwonted resolution, and the dog whip was stimulating the phlegmatic Embrocation to his utmost endeavour. He got to the head of his stable companion but no further, and by that small margin we were defeated! What a Pyrrhic victory!

"I hope I did right, sir," said Tommy, apologetically.

I do not know what answer was expected, but it was in the affirmative, as Ministers remark when they want to be terse with an irritating and persistent questioner in the House.

Obviously this was a tight and desperate finish, but had Winkelman won easily or even cleverly, no doubt nasty remarks would have been buzzed about.

Ted's other " tit" was a well-topped bay pony of fourteen hands, called Early Morn, but his forelegs would have outdone the most dilapidated cab horse, so over at the knee were they. I rode him several times but do not remember his having borne the 
black and gold even into a modest "place" ; though he was an amiable creature and a bit of a "trick" horse. If bribed with a bit of sugar he would shake hoof with hand when any of my fair friends so desired.

The Usher and Epsom Embrocation were entire colts. Both, and more especially The Usher, should have been invaluable as blood pony stallions. I am not aware whether either were put to such use, for I quite lost sight of them when my choice little string was dispersed. The Usher was one of the handsomest thoroughbreds, on a miniature scale, that could be imagined; and then look at his pedigree (as previously stated), by a Derby winner (Kisber) and with another Derby winner (Hermit) as maternal grandsire. What could be nicer?

I have not much to say in favour of pony racing as it was carried on in those days; but at Hurlingham and Ranelagh it was a quite enjoyable sport, indulged in by some of the best sportsmen and riders of the day.

This is where I first came in contact with dear old "Charlie" Beresford. I had had some sharp grit kicked into my eye during a race and came into the dressing-room in agony. Beresford, the handy man, laid me out on a form, turned up my eyelid with a pencil, and whipped out the painful obstruction. All done in the shake of a duck's tail !

The last time I saw his lordship was when fishing Lord Cork's waters on the Pang. It was a blazing day in June and there was nothing doing in the 
angling line, so we sat down in the shade and discoursed of old times and old pals, many of them gone ahead. In a few months' time, the cheery companion of that day passed along.

"Willie" Hall Walker, who afterwards was raised to the peerage under the title of Lord Wavertree, was an exceptionally fine horseman. I often wondered that he did not take to riding under legitimate rules, for he had a beautiful seat, the best of hands and perfect judgment. His average wins as compared to mounts was phenomenal. Another fine horseman was $\mathrm{H}$. C. Bentley whom I have already alluded to as the pilot of Catona. When it came to the sticks or steeplechasing, like Walker, he was well equipped for the sport toward in every particular. He was of a singularly reserved and rather lofty disposition; he never showed excitement and seldom smiled, but one day I saw him fairly disgruntled.

A special race had been provided at Hurlingham for ponies I 3.2 and under. I had nothing of this height at the time but was keen on having a cut in, so Jesse Winfield received the usual "office" and soon reported that he had "the goods" for me, which turned out to be a varmint-looking little mare named Sarah. I had nothing approaching her own size to try her with, but thought if she could make any sort of show against Catona at three stone, she would be pretty useful among the class she would be likely to meet at Hurlingham; so I arranged for a spin, 
and invited Harry Bentley to come with me to Epsom (where my ponies were at that time being trained at Woodcote Lodge) and to ride the champion for a try out with Sarah.

As it turned out, the little chestnut was no sort of use to the bonnie brown, who, in Bentley's skilful hands, simply played with her. So after going some six furlongs we made to pull up. Sooner thought of than done, as far as the sportive Sarah was concerned. I tried every kind of device, but I could not break the loping gallop into which she had subsided. She had the snaffle (a bit which I have always loathed) firmly wedged in her back grinders. When I let her head loose she dropped it momentarily, but directly I shortened rein, she had it fixed again. I thought to take her on to the Derby course and to let her run herself to a standstill, but I found that the chains were up, so I had to wrench her right round. Back she came, easy enough to steer, but impossible to stop! I swung her round a coppice on the hill, where she slipped up and sent me a pretty purler, but I was not hurt, though delighted to be separated from the fair Sarah and her irresponsible ways. She had carried me a good three miles and was now in a black sweat. My friend Bentley grew sarcastic.

"Why, what's up with you, Cockie?" he sneered. "Fancy you not being able to hold a toy like that ! You've been wasting too hard I expect."

"Oh, all right," I replied. "You have a go and 
see how you like it! The little beast has taken all the steel out of herself, but grant her half an hour's rest and she will give you the time of your life."

Well, my young paragon took me at my word. No sooner were his bony legs over Sarah than she was off! This time straight for Woodcote End, and soon pony and rider were lost to sight, and as regards the beastly little pony-by no means to memory dear! In half an hour Bentley returned leading the now thoroughly subdued tit. Nor was he himself in a particularly lively mood.

"Great Scott!" he murmured, turning to the sheepish-looking Jesse. "Where on earth did you get hold of this little devil? Why she has no mouth at all. Don't you ride her at Hurlingham, Cockie. If she does not kill you, she will charge the crowd and fill the local hospital !"

"Jesse," said I sternly, " take her to the place from whence she came and never let me see her, or the likes of her again." And so it was !

Lord Westbury's brother, Guy Bethel, was a useful little rider, and could go to scale at a nice weight.

Latham Lutwych had great success on his fourteenhand pony, The Boy (a curiously named mare). $\mathrm{He}$ always handled her to perfection. She was as unbeatable in her class as Catona was among galloways. H. T. Barclay, the owner of the bold Bendigo, the predecessor of my filly Dornroschen 
as holder of the time record for the mile, used occasionally to butt in. Later, like myself, he took up riding under Jockey Club and National Hunt Rules. A brilliant man to hounds, he could always do justice to his mounts.

These are only a few of those who sported silk at the fashionable club resorts,

There was a terrible mix up at Hurlingham on one occasion, when the leading pony slipped up in negotiating a turn; whereupon practically the whole field of seven sat down in a heap on the fallen one. A rider performed a double somersault in the air and landed on his feet, clear of the struggling mass. Marvellous to relate, with one exception neither riders nor ponies were any the worse for the mélange, which was truly horrific and nerve-startling to behold. The one exception was poor Hanbury who was carried away in an ambulance-insensible. He soon recovered, as no serious injury had accrued. But relentless Fate was dogging his footsteps ; for, very shortly afterwards, a horse he was riding (at Lewes, I think) ran into a post, and poor Hanbury was killed on the spot!

So much for pony racing. Now let us hark back to more serious business. 


\section{CHAPTER IV}

LTHOUGH well placed in our cosy little
maisonette in South Audley Street, my
soul panted for more space and purer
air. A son had been born to me, and I wanted him brought up amid the glories of Nature; moreover, I was keen on some real sport with horse and hound, rod and gun. Pony racing and pigeon shooting were all very well in their way. The latter pastime (which has been falsely accused of posing as a sport) aroused the competitive spirit which has, from my earliest days, been one of my most marked characteristics. I may have something to say about my experiences in this connection later on. For the moment I will content myself by boldly asserting that all sport is cruel, and were pigeon shooting a sport, which it is not, it must be written down as no more cruel than most gunning activities, and far less than some.

Having seriously contracted this wander-lust I began my search for a likely pitch, and found it in the advertisement pages of our time-honoured Field:

"A fine and ancient Abbey with kennels, stabling, 22 bedrooms, standing in its own well-timbered grounds, with 1500 acres shooting and first-rate 
trout fishing." These were some of the attractions offered. Forthwith I sent the faithful Ted on a voyage of discovery and inspection. His report was highly favourable. Knowing me for the keen angler I was and ever will be, as long as I can cast a fly, my hefty cousin waxed eloquent as to the "whoppers" he had seen in the narrows (it was then the spawning season) of one of the lakelets, fed by a stream named the Misburn, a little tributary of the Chess.

Without more ado I hied me to the agents, and in due course found myself fixed up with a three years' tenancy of Missenden Abbey-furnished. Thither I removed my lares and penates as quickly as might be contrived. Then came the absorbing occupation of stocking it. Horses, ponies, dogs, cats, poultry, pigeons, rabbits, pigs, cows, and other domestic details, including guinea-pigs, two monkeys and a grey parrot, were assembled, and the cry was "Still they come!"

Those who have seen Missenden Abbey will have appreciated its beauties. It was a vast place, stone flagged in its great hall, and therefore inclined to be so chilly in the autumn and winter months that my coal bill mounted to colossal figures. It took us all much time and thought to find our way about the labrynthine passages and remote quarters. On one occasion a visitor, noted for the strictness of his virtue and his purity of thought, nearly forfeited this carefully built up reputation by being found at the dead of night in his pyjamas, trying the door of an equally 
straight and rigid maiden. Of course he had lost his way and made a mistake-of course. But it is not my métier to enter into a minute description of this ancient pile and its picturesque and well-timbered demesne, but rather to chronicle the sports and pastimes, the spoofs and stunts, which took place within its venerable walls and its spacious environments.

I have stated that my earliest experience of hunting was with the Trinity (Cambridge) beagles, when those distinguished cricket "blues," George Longman (late of Eton) and George Macan (a contemporary of mine at Harrow) were joint masters.

But when I came down, and whilst yet my dear old dad was alive, I got together a motley pack at Moat Mount, with which I essayed to harry the timid hare; but that useful rodent was exceeding scarce in those parts, and it was only occasionally that a mournful sequence of blank days was relieved by a find, and then my "jelly dogs," including the lame, the halt, and the blind, would string out and disperse, each one doing a bit of hunting on his or her own, and not being at all particular as to whether the hare hit on was that of the fugitive lepus, or of the common and odoriferous coney. But I did have a real good chivvy one fine day. Most unexpectedly, a fine old Jack hare was bustled out of a dry ditch and then the fun began! Our quarry seemed to enjoy the sport and kept ringing around and giving us a kindly view of his russet fur, whenever scent failed and my 
vagabonds were at fault. Now as this occurred on the Sabbath, and the Sunday-school children ran amok to join the gay throng, there was a wailing and gnashing of teeth among the "unco' guid" of the village, who formed a deputation imploring "The Dads" to put a stop to my desecration of the Lord's Day. This he did-diplomatically; and as by this time I had used up every hare within a radius of many miles, but never accounted for one, and as my precious beagles (so called) were by now quite beyond my control, I graciously condescended to abandon my " country" and put down my " pack," after having selected three couples of the most persistent "bunny busters " to act as aids to the gun ; a duty which be it said to their credit they performed with becoming zest and efficiency. The gun was used, not with, but on, the rest, by a callous hireling, and I tried to forget that I ever owned them. But the spirit of Nimrod burnt brightly within me. No sooner were Ted and I installed with our respective wives and offspring in the Abbey, than we set about forming a harrier pack to hunt a rather apochryphal country long since abandoned, if indeed it had ever existed. At first there was a deal of squealing on the part of the Committee of the Old Berkeley (West) Foxhounds; but the farmers were dead keen on this addition to the sporting attractions of the neighbourhood, and when I gave a firm undertaking to keep my " jelly dogs" remote from all the well-established fox coverts, our little venture was tolerated. I had to 
gather together what hounds I could; consequently, to begin with, we had rather a mixed lot; but among them some really first-class material. As for the horses, I managed to pick up some useful tits. For my own riding, I hied me to Belhus, where that eccentric, but kind and cheery little old sportsman, Sir Thomas Lennard, was holding one of his annual sales. As usual, Ted had been there in advance and had seen Tom Collar, the stud groom, perform prodigies of valour on certain desirable hunters. Now in those days I had a theory, which later I abandoned. It was that if a weight-carrier could shoulder a sixteen-stone man comfortably, he would simply fly over his fences and gallop his field to a standstill when he had only eleven stone (my hunting weight) on his back. My acquaintance with the ways and wiles of the thoroughbred as represented by the rollicking blood ponies I had ridden led me to distrust the whole race. When it comes to carrying the horn and hunting one's hounds, one does not want to have head and hands occupied with an impatient and fiery bit of blood. So I went for hairyheeled specimens, of solid build, who could both gallop and jump.

Well, I got hold of some wonderful performers at Belhus, to wit, Yeoman, a chestnut of cob build who could jump anything. If he could not do it in once, " he could manage it in seven," as "Rock" (Lord Cholmondeley) once observed. At timber he was a marvel, but he had a way of coming right under the 
obstacle, pausing a moment, and then of lifting himself, all fours at once; and even so, he invariably cleared without a rap. The first time I rode him at a five-barred gate, I was not prepared for this sort of thing. Consequently I was jerked out of the saddle, and sent an imperial toss which left me guessing; but next time I was ready, and on one occasion, in the Vale of Aylesbury, I bet that I would take Yeoman over three full-sized five-barred gates in a line, and that he would not touch one of them. I won the wager all right. But this charming little chestnut was troubled with the slows. He was good enough for the "red currant " business, but when it came to hunting the wily red-skin he was apt to be like the proverbial cow's tail- " all behind,"-a very unbecoming position for the huntsman master ! So after much heart-burning and perturbation of mind I sold Yeoman to a pal, Tom Farries, partner of that peerless sportsman and prince of gentlemen, "Uncle Punch" Burbidge, and right well did the beloved cob carry his new owner.

I have a different story to tell of another of my Belhus purchases, to wit, one Melbury, a rich brown, standing quite 16.2 . He came originally from the West country, and was the offspring of a Queen's Premium stallion travelling in that district. I have no exact information regarding his dam; but was told she was " a van mare." She may herself have had a blood cross, but undoubtedly she also had the bar sinister ; for Melbury was inclined to be a bit hairy about 
the heels, and was built on modified shire lines, though he had grand shoulders and was not fiddle-headed. This was the very best hunter I ever rode. He was a magnificent fencer, and never put a foot wrong. $\mathrm{He}$ would take anything his head was set to, yet never. rushed an obstacle. He had a perfect mouth, delightful manners, and gave a firm but easy feel. He had the sweetest of temperaments. Moreover, he had a fair turn of speed and, at one time, could stay for ever, though latterly I fancy his heart became affected. It was a big one that never gave way until Nature gave out. I rode him twice a week with the harriers and, subsequently, three days a fortnight with the O.B.H.

I was on his back on the momentous occasion when, for the first time, I appeared as Master of the lastnamed, time-honoured pack, in all the glory of the "buff" (really canary) livery, at the opening meet, surrounded by my beloved hounds.

But I am anticipating, though I may as well state here and now that as I rode Melbury on the first day of my mastership, so he was my mount on the last day thereof, and in the interim I had never been off his back, except when I so willed it. He had never made even the semblance of a mistake. The day which was to close my association with the O.B.H. was to end the life of my bonnie brown hunter. I had changed horses in the middle of the day and, on my return after having kennelled my pack, I was met at the door of my home (then Chorley Wood House) by my valet Bedford. 
I saw that there was something wrong, as he wore a very serious look.

"I have bad news for you, sir !"

"Out with it, man" (I had a mysterious intuition).

"Something's the matter with Melbury?"

"He's gone, sir."

"Dead?"

"Yes, sir ; when George (George White, my second horseman) got him home, Melbury was seized with gripes or something and was cast in his box. Before we could get the vet. it was all over."

A tragedy indeed, and under the circumstances, painfully dramatic.

Now to hark back to my "jelly dogs."

Shortly after I had begun hunting the problematical Missenden country, I received a communication from Mr. Cripps, Q.C., of Parmoor, near Marlow, asking if I would care to take over his harrier country. $\mathrm{He}$ was then over eighty years of age, and though hale and hearty, he confessed that he did not feel equal to carrying on with the Hambleden Vale pack. At his invitation I went over to Parmoor with the ever-ready Ted, on a voyage of discovery. We were most hospitably received, and had an opportunity of witnessing the work of the harriers, a very level and useful little lot, hunted by a charming old fellow, William Snaith, of low stature and high voice, who consented to come with the pack and to act as kennel huntsman. From him I had many a useful wrinkle which served 
me in good stead in the outwitting of the tricky and elusive hare. When I took on the O.B.H. this worthy became my coachman and stud groom. At Parmoor I met the Cripps family, the eldest of whom, when raised to the peerage, took the name of his residence for his title. The second son Harrison, with whom I struck up a pleasant friendship, became a celebrated surgeon, and being an enthusiastic salmon fisher as well as an all-round sportsman we had much in common.

With the Hambleden Vale pack and my own to choose from, I was able to select the best hounds from each and draft the surplus; so that I now had a level, handsome lot of workers to represent the amalgamated "Missenden and Hambleden Vale Harriers." In connection with this drafting I have a strange tale to tell, which illustrates to a remarkable degree the homing instinct possessed by the canine race.

Two couples and a half of my draft I sent to a brother M.H. in Wales, as being an inch below my standard ( 18 ins.). They were coupled up and placed in the guard's van, which was closed in so that they could not possibly see the country through which they were passing. They were safely delivered, but the following day I received a wire from my friend which ran : "Your hounds broken kennel and disappeared. Please make inquiries your end."

For three days nothing was heard of the truants, but on the evening of the third, the K.H. was aroused 
by a dismal whining outside the kennels and a devil of a rumpus within. Quickly throwing on some garments he sallied forth to find a couple and a half of the draft that had been sent to Wales at the door of the kennel in a pitiable state. They were nothing but skin and bone, and the pad of every foot was raw or blistered. One of these poor, faithful creatures, a bitch appropriately named Truelove, was at her last gasp, and in spite of unremitting attention she passed away; whilst it was weeks before the survivors regained anything like condition. As for the missing couple, nothing was ever seen or heard of them again; their fate was a mystery. Needless to say that Pilot and his brother Pieman were not sent back to Wales. I preferred to refund the cheque for which they had been exchanged, and to overlook their want of an inch in height.

Verily we of the M. and H.V.H. had a merry time. In addition to the venerable and squeaky Snaith I had three others in the green livery to whip in to me, viz. the inevitable Ted Jaquet, and my brothers-in-law, Ronald and Wilfred Barlow, neither of whom had previously had experience of equestrian exercise; but they took to it like ducks to water, and soon became efficient and helpful horsemen, though at first they bit the dust with monotonous regularity. Their sisters, Miriam and "Freddie," were even more enthusiastic, and shaped so well in their apprenticeship with the boys in green that in later days, when following "the 
buff," they were looked upon as the finest horsewomen of the O.B.H. As long as the supply of fur held out we could always be sure of showing first-rate sport ; especially in that part of the country which included the grass lands of the Aylesbury Vale. Here was a gallant race of hares. If and when found, puss, after one ring, would go straight off to the Chiltern Hills, sometimes giving us a burst of over two miles, cut short on some occasions by a "worry worry" ; for my little jelly dogs could hop it to a lively tune when scent was propitious or when they could race away, close to the scut.

But there came a time when the numbers of the quarry became smaller and smaller, and unbeautifully less, for this was in the days when the effect of "the Ground Game Act" was beginning to make itself unpleasantly obvious.

So there were occasions when even the keen eye of Jack Westrup, and his intimate knowledge of the ways and wiles of "Madam" failed us. Blank days were all too frequent, and at last I was driven to the purchase of a hard-bitten stag, to vary the monotony and to give our farmer friends and other followers a bit of a gallop. Personally I hold no brief for staghunting in any shape or form. Least of all the hunting of the so-called "wild" beast by the Devon and Somerset S.H. I have heard those cranks who want to differentiate between the degrees of cruelty entailed in the pursuit of field sports say sententiously, "I can 
understand the hunting of the wild stag on Exmoor, that is true sport; but to chase a poor deer, released from a cart, until it dies of exhaustion, drowns itself, or is impaled on a spiked paling, I call it, not sport, but diabolical brutality." Which, of course, is a betrayal of crass ignorance such as is to be expected from those who, after inserting a wedge to eliminate sports-the cruelty of which is obvious to the man in the streetare bent on driving it home, until our primitive sporting instincts are entirely exorcised, and we become a nation of sentimental degenerates.

Now what is the truth about these two forms of staghunting? The wild stag is pig fat and has the burden of his antlers to carry. He is chevied out of his native fastness by " the tufters," and having been allowed what is considered sufficient law, the pack is laid on, and never leaves the line until the quarry sinks in what he imagines to be a friendly stream, or takes to the open sea. In the first case, he is lassoed; in the other he is " taken" by boat. In either case his throat is slit. The country will not admit of riding to hounds as foxhunters understand the term. There is no fencing and precious little excitement. Now for the hunting of the carted deer. $\mathrm{He}$ is in as perfect condition as a trained race-horse. He has been deprived of his head honours, and is fit to run, not for his life, but to give the hounds (whom he knows and fears not) and the field a good run for their money. When he is tired of the journey and feeling fed up with the sport, he looks out 
for a convenient stable or farm building. Then he calmly awaits the arrival of the pack and its attendants with a comfortable conveyance to take him back to his paddock, where he will have an excellent repast, and sleep the sleep of the just. I remember on one occasion hunting with the Queen's when a thick mist descended. My faithful Ted and I got lost, but chanced across some of the stragglers of the royal pack. Keeping close to their sterns we were half across a twenty-acre field when we came up with the main body, who had their stag at bay in the open. The latter was quietly browsing, what time an enthusiastic hound or two, venturing too near, would be contemptuously but not ungently "hoofed" away by the stag. We had visions of a ghastly tragedy and " a poor, hunted victim being torn to tatters by the ferocious pack"; so we were prepared to do battle to avert the catastrophe, but nothing happened, and presently Goodall and his merry men came up and relieved us of our responsibility.

I never did much hunting with the D. and S. Three days was enough for me, but on the last I had an experience which falls to the lot of very few, yea, even of those who, season after season, have devoted themselves to stumbling and plunging over the picturesque banks, trees, burns, and bogs of Exmoor. I had been told that the tip was to hire a local gee, used to the game, and by no manner of means to bring my own fox-catchers for the job, so I went to the well-known job-master White, of Minehead, and told him what I 
wanted. Seeing that I was a light weight with some sort of reputation as a gentleman rider he showed me a pretty little chestnut blood mare about fifteen hands, and assured me she was "It" for the purpose toward.

Well, when I accompanied Mr. Bassett to the tufting stunt, I stood at the corner of the big Cloutsham covert all agog; whilst the old hounds were " chowking" away and driving the stag into the open. Byand-by there was an awful crashing in the undergrowth, and out burst an animal, which to my startled eyes appeared about the dimensions of a No. I fullsized elephant. Moreover, he carried, as far as I could see, "royal " honours. Not that I had much opportunity of counting the tines, for Daisy, the little lady who bore me, and who might have been supposed to be acquainted with stags in all their glory, was so startled by the sudden apparition that she reared up on end and fell backwards, but luckily without imposing her weight on my recumbent form. As soon as I had regained my breath and the saddle I began to exploit my very best "View Halloas." Presently the master rode up.

"Good God, Cox, what has happened? Are you hurt?"

\section{"Hurt? No!"}

"Then what's all the row about?"

"Why! " yelled I, all excitement, " a big beast has gone clear away over the open. If you get the pack I can put you straight on the line." 
"My poor friend," sighed Bassett indulgently, "don't excite yourself; there's heaps of time. We'll take up the tufters and go and have a bite and a glass."

"But are you not going to hunt the stag? Surely he's one of the right sort?"

"Of course, my good fellow, all in good time. In twenty minutes we will get a move on. Come along."

A strange proceeding, but I had to be content.

In due course the pack was laid on, and the gay throng crowded after. Daisy could gallop a bit and was handy, so I soon threaded my way to the front rank. The hounds broke over the heather-clad moor. I was now close up with them and highly pleased with myself. I looked round; I was the one lonely horseman on the open expanse. Huntsmen, master, whips, and the field had disappeared as if the ground had opened and swallowed them up, which a moment later it did in my case. The little chestnut turned turtle and I was sent flying-an interesting performance which she repeated before another half mile had been covered. In both cases she had come to grief over a boulder hidden in the heather. I thought these native tits knew all about such lethal traps; it seemed not. The hounds were now well ahead and sinking a deep and precipitous nullah or chine. They crossed the Barle and streamed away, up the opposite slope. I was pounded fairly and squarely. No more hounds or stag 
for me that day. When I took Daisy back to White, I inquired as to why she had been so acrobatic.

"Well," said the genial dealer, " you see, sir, she's a bit new to the country, she only came down from Tattersall's day before yesterday."

"But you didn't tell me that?"

"Well, no sir, she was the only nag I had free, and I didn't want to disappoint you. Besides, you being, so to speak, a bit of a horseman, I thought you would fall light."

"Oh, thank you very much-and so forth!"

Next time out I had a good hunter mare provided for me.

"She pulls a bit, Captain Cox, but you won't mind that," said the head lad.

" Oh, won't I, but I do! I simply loathe pullers ; but as it's Norah or nothing I suppose I must have a dart."

And she did start pulling, but I was able to keep her enthusiasm within reasonable bounds, so that, by the end of the day she was quite handy. I had the privilege of following a farmer who knew every inch of the moor, and though I never caught sight of hounds until the kill, I had the doubtful pleasure of seeing the stag roped out of the river Barle and slaughtered.

My third and last day found Norah booked for no less a personage than my friend and brother "rider" Roddy Owen, prince of horsemen and best of good fellows. But this time the dealer had a real nice blood 
mare called The Duchess for me. Roddy and I, having been lost in the run, chanced upon one another a mile or so outside Minehead. We were jogging along quietly when suddenly we became aware that hounds were running in the vicinity. Presently the hunted stag bounded on to the road and down it, with the leading hounds, on a hot line, not three hundred yards behind. As soon as they appeared on the macadam the stag flew the palings of Dyke Acland's Park and, landing on the turf, sped straight across the open. The whole pack followed suit. We galloped to the lodge gates and entered the park just in time to see a really unique performance; for the hounds got a view of the quarry and racing him down on the smooth turf, bowled him over in the open, as foxhounds would the little red rover. Whilst the obsequies were being performed by the huntsman (a namesake of mine) Roddy and I stood by. I was taking a pull at the flask he had thoughtfully handed to me; whilst he was lighting a cigar.

Suddenly, without warning, The Duchess gave a piercing squeal and bounded into the air, all fours at once, sending me flying skyward, and took to her heels. There I sat, in a state of disgruntlement, whilst Roddy was seized with a merriment which threatened to develop into apoplexy. He was enjoying himself too acutely to be capable of articulation. But whilst at the acme of enjoyment, the sprightly Norah gave a first-class imitation of Her Grace the Duchess's 
evolution, and in a moment Roddy was seated beside me, whilst his mare galloped off to join the other deserter.

"Who the_? What the_? ?" began the fallen hero of a hundred races; then, "Here, I say, damn it all, Cockie, we're sitting on a wasps' nest ! Run for your life," and we did.

The mystery was solved. Both our mares had been stung.

So much for stag hunting. I am glad to be quit of it, although Ted has a glorious tale to tell of how, when I was away endeavouring to catch the judge's eye at Sandown, Bibury, or some such venue where owners, trainers, gees, and riders of sorts most do congregate, a message had come down from H.M.'s Huntsman to say that a deer had been left in our neighbourhood and would the M. and H.V.H. kindly take it, or hunt it home. Here was a gala gaiety for my cousin, who wired me for leave to proceed. My reply was "Carry on!" They found the outlying beast all right, and according to His Nibs, he hunted it from early morn to dewy eve, nine mortal hours on end, and were only defeated by the sombre shades of night. Bully for Ted, but no more hare harrying for me for a fortnight, with 25 per cent. of my precious "jelly dogs" still on the sick list!

Those who like it, may stick to their stag hunting. What is one man's meat is another man's poison. 


\section{CHAPTER V}

TUST a few more words that touch on pony racing, inasmuch as Missenden witnessed a celebration which excited much local interest. We had not been long established at the ancient Abbey before a brain wave struck us. Why not get up a meeting of " the miniatures"? No sooner thought of than carried out by the genius of organization possessed by Ted. One adjacent field lent itself tolerably well to the venture, and all went swimmingly. My friends of the cult rallied to the call nobly, and we had quite a representative entry. Among those who patronized the meeting being J. B. ("Bunny ") Leigh, "Gratty" Blagrave, and one Charlie A'Court, afterwards known in the Great War as "Eye Witness" otherwise Col. C. A. Repington, whose "Reminiscences" afterwards created such a flutter in the social dove-cotes. These were not the days of Catona, Etna, Epsom Embrocation \& Co. ; but that useful mare of all work, Phyllis, nobly represented the home string, and what is more, helped me to lift a couple of races.

There was an event open only to horses ridden by patrons of the M. and H.V.H., in which I had entered 
the trusty Yeoman, relying on his undoubted prowess as a lepper to do me honour, despite his woeful lack of speed. Certainly he jumped the far from formidable obstacles brilliantly, but he was outpaced at the finish by a gee, ridden by his owner, an enthusiastic supporter of my harriers, of the name of Ackerman. This one had not figured prominently in the betting, since all and sundry had been obsessed with the false impression that the steed was a mare heavy in foal ; whereas it turned out to be a gelding with a "Little Mary" distended by a too liberal diet of grass. The rest of the field either fell down, ran out, jumped their riders off, or pulled up suddenly in order, I suppose, to reserve their energies for a more fitting occasion, or to browse on the rather profuse herbage.

"Gratty" Blagrave was supposed to have a red-hot rod in pickle for the great event of the card, but for some reason or other the good thing came unstuck. Oh yes, taken all in all it was a merry and genial day's leather flapping.

Ted's report anent the leviathan trout was in no way exaggerated. I watched the ponderous fish as they disported themselves on the " redds " and longed for the day, when well " mended," they should reseek the lakelets and condescend to take notice of my artful lures.

A favourable day in March prompted me to make an early attack; but I fished the whole stretch of the waters without response until, on my return, something 
in the way of an angler's intuition induced me to present a "February red," at the head of the pool nearest the manse. I cast well out and sure enough there was a lusty boil, my rod bent and my reel sang as the line was run out half across the expanse. When safely netted the fish proved to be a nice trout of close on three pounds, in very fair condition, considering the time of year. Urged on by this success I tried the whole stretch again, but nothing of note happened. In April, May, and June, I had some fine sport with the rod. One fine evening during the last-named month of roses, taking with me young Andrew Limehouse (who afterwards became head lad in my greyhound kennels) as a sort of piscatorial caddy, I repaired to a deep stream which connected the penultimate with the furthest pond. The night before I had seen many big fellows cruising up the far bank, feeding freely, and I had made up my mind to a mighty raid as soon as the sun should set. When I arrived no bulges or swirls disturbed the placid surface, so I sat down, lighted my pipe, and waited patiently. The fish were tardy in making their approach obvious. It was not until a rising moon glinted on the water that Andrew touched me on the arm and pointed to where silvery rings were breaking and spreading close under the opposite bank. Hurriedly I affixed a medium-sized "coachman" and measured my cast so that the fly should drop right under the overhanging ledge. Waiting until the feeding fish came within comfortable reach 
I dropped the white-winged lure a foot in front of his nose. He had it in a moment and I was fast in a good one. After putting up a strenuous fight he gave in and came to the net, deftly handled by Andrew, $2 \frac{1}{4}$ lbs. -a good start! It was now almost dark, but there was a luminous patch where the moon's rays struck, in the centre of which I religiously placed my fly. Fish after fish came to it, and to cut a long story short, I creeled four and a half brace of beauties ; the biggest $3 \frac{1}{2} \mathrm{lbs}$, and not one under $\mathrm{I} \frac{1}{2} \mathrm{lbs}$. Then I strolled home, happy and triumphant, only to find that my friends and my guests, after giving me half an hour's law, had fallen upon the flesh-pots like a swarm of locusts, leaving me only the husks of the feast to satisfy a gargantuan appetite. Moreover, my C.O., instead of sympathizing with and extolling my skill with the angle, read me the Riot Act, and ticked me off severely for my negligence in vacating the head of the table in favour of " a few wretched trout," which I could catch at any time. What a lack of understanding ! And yet some admirers of the sex are good to maintain that the sporting instinct is as strong in women as in the mere male, if but given a fair chance!

Now, as it happened these same trout proved our undoing, and brought to an untimely and undesired end our delightful occupation of Missenden Abbey. It was in this wise. It seems that the Misburn, the little stream that ran through, and linked up the chain of lakelets, had a nasty habit of drying up 
every seven years, because, so it was stated, the springs which formed its source in the Chiltern Hills, failed. These springs were in the vicinity of Chequer's Court, then occupied by Mr. (afterwards Lord) Lee of Fareham, who so generously bestowed the ancient home on the nation, to serve as a residence for Britain's Prime Ministers. Many a good run had I from there in after days with the O.B.H. But that is another story. Well, it so happened that the periodical drought was due toward the second year of my tenancy. With a punctuality which was hardly appreciated, the flow grew less and less, until it became a mere dribble. Then it ceased altogether; and consequently, the ponds became lower and lower, and the water so stagnant that the fish fell sick and began to turn on their backs. Anon there were only a few isolated pools overcrowded with dying trout. The stench was becoming unendurable and the whole place rendered uninhabitable. What was to be done? An application to the agent of the owner met with a dilatory and highly unsatisfactory response. No time was to be lost. I wrote to the Marlow Angling Association to send over water carts, for the conveyance of surviving fish to the Thames. The invitation was promptly accepted, and close on two hundred trout were released in Marlow weir pool. Then we packed up and emigrated, bag and baggage. But we were not to be allowed to depart in peace. A writ was issued claiming heavy damages, the principal item being the value of 
fish "wrongfully" taken from the "water" (save the mark!) and "improperly" placed in the Thames. When the case came into court I paid in what I considered to be a fair compromise, arguing that, if I had left the fish to die, it would not only have been a cruel and unsportsmanlike proceeding, but might well have caused a dangerous epidemic in the neighbourhood, and that, as it was, we had been deprived of reasonable and undisturbed occupation. The answer was that the drying up of the Misburn was due to "the hand of God," and that the owner was therefore not responsible.

Then I played my trump card. Cross-examination of the plaintiff elicited the admission that the peculiar habit of the stream of drying up every seven years was a known and well-recognized fact; that such drought was due in the middle of my tenancy was obvious, but that I had not been warned by either the said plaintiff or his accredited agent. Then the learned judge took a hand in the game and strongly advised my adversary's counsel to take, on behalf of his client, that which I had magnanimously paid into court whilst he could get it ; adding that, in his lordship's opinion, plaintiff must be accounted uncommonly lucky to have the opportunity of so doing.

This was a woeful ending to a really glorious time. There had been always something doing at the Abbey; hunting, shooting, fishing, dog breeding, breaking and exhibiting; crowds of good sportsmen as guests, village entertainments, dramatic and otherwise; hunt 
suppers and elaborate practical jokes of a highly entertaining but harmless nature.

Several young couples, meeting for the first time under our roof, became mutually enamoured, and either sought the altar, where they were condemned to bondage until death or the Divorce Court should release them, or until one or other of the betrothed found that their choice of the moment was but a will o' the wisp-the empty shade of an ideal-which had subsequently melted into nothingness; and so pulled up and unhitched just in time!

I have mentioned that during my third season as Master of the M. and H.V.H. hares had been so scarce that I was in despair ; consequently, after much heartburning, I made up my mind to allow the Hunt to lapse.

It was at this juncture that Austen Mackenzie of Taplow Court, Henley, having been offered the Woodland Pytchly, sent in his resignation as Master of the O.B.H. (West). At the same time Mr. Longman, who had, for many seasons, hunted the East Division of the country, unhappily found his eyesight failing him ; so he, too, announced to his committee that he would not carry on after the close of the season. Now it so happened that one of the best friends I ever had was "Fred " Burbidge, whom we dubbed "Uncle Punch," because of his supposed resemblance (in face only) to that hump-backed humorist. $\mathrm{He}$ and his wife resided at Micklefield, near Chorleywood. I had 
become acquainted with him when, just after I had come down from Trinity, I inaugurated the Fox Terrier Club; for he was an enthusiastic breeder and exhibitor of this most charming of the smaller canine breeds. Later on I hope to have something to say about this industry and pleasant hobby, but I am now on the hunting lay; though it is convenient here and now to remind all and sundry that Fred Burbidge was one of the very best all round "sports" of "the old brigade." $\mathrm{He}$ was a member of the early "All England Cricket XI," and could hold his own at any game. As a boxer, he was practically supreme at his weight-that which is now styled "light heavy," or perhaps "cruiser" - and was a skilled cuest. $\mathrm{He}$ and "Aunty Emmy," his better half-an accomplished horsewoman, though somewhat handicapped by rheumatoid arthritis-often patronized the M. and H.V.H., and he it was who now approached the committees of the two O.B.H. divisions with the suggestion that they should amalgamate, and that the mastership of the whole country should be offered to my unworthy self.

A meeting was convened at the Euston Hotel, which I was invited to attend. A long conference was held, the while I cooled my heels in the passage. At last "Uncle Punch," who held an unofficial brief on my behalf, came out.

"Cockie," he began, "the committee wants to know whether, in the case of its deciding to offer you 
the Mastership, you propose to carry the horn yourself ?"

"Why, of course," I replied; " that is the beginning and end of my ambition, a brass-bound sine qua non."

"Do you want to be a really popular Master ?"

"Why, certainly!"

"Then, my Cockie, if you will take my advice you will employ a professional huntsman."

"Nothing doing, uncle! I would as soon allow a servant to handle my hounds as a keeper to shoot my pheasants or a gillie to play and land my salmon."

"Is that what I am to tell the committee? If so, old chap, I am afraid they will turn you down."

"Let them," I said. "I have no desire whatever for the social kudos which attaches to the M.F.H. I am out to show sport and incidentally to enjoy it myself. I have served a useful apprenticeship with the " jelly dogs," and I flatter myself I have enough brains and initiative to tackle the other game. I know that I have much to learn, and that it will take time before I am really efficient; but I tell you what, Uncle Punch, tell them that I am willing to engage a professional to act as kennel huntsman and to ride in my pocket until I feel my feet, so to speak. If the committee will accept this compromise I am content, otherwise it's all off !"

And they did accept. For why? They were cornered and had no other card up their sleeve. 
And now came the problem of the pack. It is true that Mr. Longman was willing to sell his little lot en bloc; but from what I had seen of them I was not greatly impressed. Moreover, I considered the figure quoted to be much too inflated. Austen Mackenzie was taking his pack with him to Brigstock, where, some time previously, I had spent happy days with Lord Lonsdale and his sporting friends and relatives when he was hunting the Woodland Pytchley country. The Lowther family is linked up with the de Fonblanquesmy mother was a daughter of the judge of that ilk-by marriage ; but I became acquainted with the ubiquitous and popular Earl through our mutual love of a good terrier. At Lowther Castle a famous old strain had been fostered for generations ; but through " in breeding," or some other cause, it had deteriorated. His lordship, having heard that I was something of an expert in this line, wrote me an interesting letter telling me all about his strain, and asking my advice as to its regeneration and betterment; whereupon I offered to send him, to Brigstock, a coupled of stud dogs which could be used as occasion might require. An invitation to visit the hunting box followed, and a very happy and interesting time I had of it. The Earl had married Lady Grace Gordon, sister of the then Marquis of Huntley. She was a sporting enthusiast, and so were her sisters, Lady Maggie Gore, Lady Elena Wickham, Lady Ethel Wickham, and their respective husbands; whilst her brothers, Lords Esmé and 
Granville Gordon, were beaux garçons, and good all round sportsmen.

What Hugh Lonsdale does not know about foxhounds and the breeding and hunting thereof is, to use a vulgarism, not worth knowing. For hours after the others had retired to rest I would, metaphorically speaking, sit at his feet garnering knowledge, which later on served me in good stead. So it was from my noble friend that I sought advice when the question of acquiring a pack to hunt the O.B.H. country arose. My appeal met with a ready response; for when we met, he informed me that he had arranged with Mr. (afterwards Viscount) Chaplin to lend me his Blankney hounds. This was indeed a godsend! I called on the Minister of Agriculture that was to be at Sutherland House, St. James', which had been lent him by his brother-in-law, the Duke. I was received in the kindest manner, and the Squire of Blankney gave me details and many useful hints as to the merits of the hounds and the lines on which he had gone in breeding them. It seems that my friend Lonsdale had taken unto himself the pick of the bitch pack, but there were some useful hounds in the mixed lot left over; quite sufficient for my purposes, and forming a nucleus from which, with various couples picked up at auction, would enable me to get together a level pack in the course of time. The young dog entry, which his lordship had not touched, contained some first-class hounds, bred from Belvoir and Broklesby strains, judiciously blended 


\section{CHASING AND RACING}

with the blood of Lord Portsmouth's Sailor. All this took place during my last summer at Missenden Abbey. Then another problem presented itself. What kennels were available? This was solved by the kindness of Lord Carrington of Wycombe Abbey, who placed at my disposal those which had long fallen into disuse, but which were in tolerable repair, and situated close to his lordship's stables. So now I was fairly fixed up and launched upon the duties and responsibilities which I had so lightly shouldered. Another piece of luck came my way, as Lord Chesham of Latimer, the Master of the Bicester, passed on to me his kennel huntsman, William Wilson, who proved a perfect treasure, and a mentor on whose advice I could always implicitly rely. 


\section{CHAPTER VI}

7 HE cubbing season proved an excellent apprenticeship, enabling me to become familiar with the country and to bring the hounds to hand in workmanlike fashion. This last I found a labour of love, for I have always flattered myself that a mutual understanding exists between the canine race and myself. I was assiduous in my attention to kennel work, and soon became on most affectionate terms with its inmates; so that when the regular season opened I was able to make a very decent showing, as amateur huntsmen go; though there were not wanting those who, possessing voices out of all proportion to their knowledge and experience, voted me slow, and put down the alleged fault to the influence of my hare-hunting amenities. But I took no heed and "ganged my gait" gaily enough. My game was, and always has been, to hunt my quarry, be it fox or hare, fairly and squarely, and not to lift my hounds, simply for the purpose of affording my followers a spurious race over the country.

About this time, the time-honoured Curraghmore pack, hunted by the late Lord Waterford, came under 76 
the hammer. I managed to secure three and a half couples of the glorious bitches. Blanche, Lady Waterford had long been disabled from hunting, but her interest in the celebrated pack never waned, and it was a sad day, as she informed me, when it was dispersed. She wrote me a charming letter entering into minute details concerning each bitch that had so fortunately come into my possession; heartening me by her congratulations on my having secured the flower of the pack. Indeed, these bitches proved of inestimable value, not only in the field, but in the harem. It is generally agreed that it takes even a knowledgeable houndman at least seven years to produce a good and level pack from draft stock, however well bred; but at the end of my third season it was freely admitted, by some of the shrewdest houndsmen and huntsmen in the kingdom, that I had got together as smart a little lot as any enthusiast might wish to follow.

The combined divisions of the Hunt which I had taken over presented physical features of great variety ; consequently a distinct type of hound was required for each. To meet the situation I divided my hounds into three sections. (I) The big dog hounds; (2) the big bitches and smaller dog hounds mixed; and (3) the little bitches; sometimes drawing from the tally of each, hounds which were of approximate inches to the larger or smaller ones, as the case might be, in the other sections. Thus I found that the big dog hounds 
were the most suitable to the great, straggling woodlands of the West. They were steadier and would be always nosing forward without faltering; whereas the little bitches were more flashy, and unless they had a very strong and straight line, would appear to be all at sea, and would hang about, waiting for me to take them in hand or to a view halloa in the open. On the other hand, get them away on fair terms with their fox, over a nice piece of grass, or scent-holding ploughed land, and it was a case of "catch 'em if you can!" They were brilliant in the extreme, and if in difficulties, Wedlock, Speedy, Beauty, Blossom, Rhoda, or other of the "stars" would soon put the rest right.

The mixed pack, with the interchangeable hounds of both sexes, were for general utility. For instance, whenever I drew "Dear old Bricket "- some called this Wilderness of Wonder by a less affectionate adjective, also beginning with $\mathrm{D}$-this was the lot drawn. This same Bricket Wood is a haunting obsession, at once a Mecca and a Hades. It is of great extent, and acres of it are quite impenetrable for a horse. One thing in its favour was the fact that a fox could always be found there, but when set on foot, the question as to whether he would be driven out was highly problematical. Moreover, these local "red skins" were given to indulging in a game, evidently diverting to themselves, but apt to make any huntsman feel utterly fed up and weary of life. The joke 
consisted in the humorist " going away "in a grand style over a twenty-acre field. On reaching its limits he would slip along at right angles and return by the side hedge to covert. I have had this trick served on me time after time, although there had been no question of the wily brute having been headed. He was always given a fair field and no favour. I tried placing " stops " or outposts close to the covert, on either side of the open space; but the red rover would simply slip by them with a derisive whisk of his brush and re-enter the tangle. The original comedian must have imparted this merry jest to his descendants, for all the Bricket foxes seemed to know and enjoy its exploitation. I never remember to have had a good run from this woodland labyrinth; but often-when late in the season I had drawn covert after covert blank-I would catch hold of hounds and trot them off to Bricket, simply for the joy of hearing the crashing chorus of a find and the inspiriting tones of Tom Goddard's "holler"; though I knew perfectly well that this little episode would prove the beginning and end of the day's sport.

Hunting the whole of the O.B.H. country five days a fortnight, with frequent by-days, was a tall order and a costly one ; but I was as keen as mustard on the job and perfectly happy, despite the adverse criticism of captious critics such as unfortunately infest every hunt ; for I had many good friends and true, ever ready to support and encourage me. Here, 
for instance, is an example of the illogical and ignorant argument of a certain noble lord.

"Oh, yes," he told a visitor from "the Shires;" "ours (the hounds were then my own particular property) is a really splendid pack, but our master is no huntsman."

He received a severe snub ; for the said visitor, who had forgotten more than his lordship ever knew about hounds and the art of hunting, replied-

"That can hardly be, my lord! A bad huntsman cannot make a good pack!"

Now this stranger from "the Shires" was-who do you think? None other than the redoubtable Tom Firr, who, with Frank Gillard of the Belvoir, had judged my puppy show during the previous summer. Am I not justified in wearing this feather in my cap? Especially since it was supplemented, the following year, when Lord Chesham and his relative, Lord Valentia (then master, if I remember rightly, of the South Oxfordshire), took a busman's holiday with the O.B.H., together with the said Tom Firr. His Lordship of Latimer, after a real smart run, accompanied me and the hounds back to kennel.

"Cox," he said, "I am going to make you blush."

"How, Lord Chesham ?" I asked, adding, "I am afraid I am past such a weakness-fire ahead !" "Some of your 'dear friends' have been sneering 
at, and crabbing you to me ; so I asked Tom Firr what he thought of your performance. His reply was, 'I have never seen hounds better hunted.' There! what do you think of that? May I remark that I heartily endorse his opinion?"

Vanity and colossal conceit of me to publish this, you will say! I don't care! I have reason to be proud of the pronouncement; especially in view of the persistent way in which some of my followers (members of the committee, too, who should have known better) belittled my efforts from the very commencement of my mastership.

I should not have known what was going on behind my back had it not been for the invaluable information conveyed by the redoubtable Ted, who not only relieved me of the clerical, financial, and managerial duties attaching to my office, but also acted as Field Master, a position which was by no manner of means a sinecure; for at times I was hampered by very plethoric and unruly fields, apt to over-ride hounds, foil the line, head the fox, and make themselves generally objectionable. But Ted was a solid stand by and managed-by firmness tempered with tactto keep them in something like order, so that I was able to concentrate on my hound work, and my one objective, viz. the legitimate hunting of and accounting for "Joshua."

But, even so, my task would have been a particularly puzzling and arduous one (for the physical 
peculiarities and varieties of the huge country rendered it one which took an infinity of "knowing ") had I not had the constant and thoroughly sportsmanlike guidance and advice of Bob Webber, of Croxley Green (who succeeded me as M.O.B.H.), for he knew every inch of the country, the normal run of the foxes, and where, and under what circumstances, they were likely to be "At home" to my call. Bob was a heavy weight, and therefore not one of the flying division; but he was always there, or thereabouts. Huntsmen as a rule dislike any particular individual who persistently rides in their pocket; but I not only encouraged Bob to do so, but was unfeignedly thankful and grateful for the fact. He was an enthusiastic hound man, as distinguished from a rider to hounds, for he was a constant visitor to the kennels, and took as much interest in what I may call the personality of each unit of the pack as I did, which is saying a lot.

I have noticed that not one in ten who poses as a hunting man knows one hound from another, or cares a tinker's curse about them, so long as, jointly considered, they can furnish a bright run in which he can display his horsemanship for the benefit of the admiring fair, or the envious hatred of male rivals.

If only those who patronize a particular hunt would devote a reasonable portion of their time to visiting the kennels during the summer, and becoming 


\section{CHASING AND RACING}

acquainted with the inmates, they would find their enjoyment of the game more than doubled, when the season begins; especially if they have been cubbing during the educational phase, and have noticed the progress of the young entry.

Others who were real sportsmen and sportswomen-besides my own domestic crowd, "Uncle Punch" and "Auntie Emmy"-were the brothers Clutterbuck, J. B. Cowley, " Jimmy Woods" (a young farmer, with an equally charming wife, one of the very best, a thorough sportsman and a perfect specimen of Nature's gentlemen), and George Gurney, a Silver Ring penciller, to whom I have already paid tribute in my pony racing reminiscences.

Mention of this excellent sportsman recalls an incident which had escaped my memory when setting forth my pony racing experiences. It was by no means a heroic episode. The scene is laid at Wye. I had ridden one of my string to victory and was all cock-a-hoop; so when a certain owner asked me to ride a pony of his (called Miss Westbourne) in a subsequent race, I jumped at the offer. Happening to meet George Gurney I told him of my projected ride. "Don't you, master!" he said. "She is a mad brute, and will give you a rough time!" (as indeed she did); but I scorned to funk the adventure, with the result that, after finishing a poor third, I was taken twice round the course by the flighty one before I could pull her up. The Usher and Sarah were 
soft-mouthed and amiable beasts compared with Miss Westbourne.

At this time I had unrestricted enjoyment of the excellent fishing on the Chess, which runs through the Latimer demesne, where I enjoyed some perfect days and evenings. On one of the latter I had something like a repetition of the fishing adventure at Missenden, as recounted in an earlier chapter ; for late in May I discovered a run at the foot of a fall, where the big fellows, in single file, procured nightly their entymological rations. It was a case of " One landed, t'other come on !" until I had four and a half brace of beauties (not one of which was under 2 lbs.) laid out neatly in a row. Here again "the coachman" proved what a deadly fly it is, of a late spring or early summer evening, after sunset.

The shooting was not so good, but it was a pleasant interlude on off days, and we generally managed to make a respectable mixed bag. But the best of sport with the gun was that which I enjoyed on the extensive farm of the before-mentioned "Jimmy "Woo'ds ; for it was well stocked with the little brown birds, and as Jimmy and his other friends were deadly shots, our tally was a very satisfactory one.

I had one or two good days with the Drakes at Shardeloes. Here I was up against a very deadly wielder of the gun in the person of the rector of Amersham, a sporting parson of the old school, the Rev. Edward Drake, to wit, who made a name for 
himself and the Church by riding in the Grand National and completing the course, under the assumed name of Mr. Ekard, which nom de course resolves itself into the simple expedient of spelling his rightful patronymic backwards. He was a brother of the then reigning "House of Shardeloes," and like all of the clan, was inclined to be somewhat dour and reserved; except in his language in the fields of sport, which was apt to be anything but clerical; but he had a touch of dry and caustic humour, which was very effective in checking the exuberance of irresponsible youth. His cousin "Mutey," so-called because he had distinguished himself in the India Mutiny, was of a far more jovial and genial disposition, and he and I foregathered most pleasantly. When finally I resigned the O.B.H. country it was again divided into its original sections, East and West; Bob Webber taking the former and Capt. "Mutey" Drake the latter.

To return to "The Rector." First time we met in the stubbles and roots he had evidently made up his mind to take my number down, for he had heard of my triumphs at the traps and wanted to show that such shooting was of the tricky order, and that an AI game shot would always assert superiority. As he undoubtedly belonged to the latter category his theory only remained to be proved. Well, it was a close thing; but it gave him furiously to think when, to commence with, a bit of rough stuff where birds could 
not be walked up was driven. They came over at top speed, down wind and very high. By a lucky fluke I accomplished a startling right and left. (I say " lucky fluke," because I have always considered that driven partridges show up my weakest spot.) Sometimes I was almost brilliant; at others, after muffing my first shot, I would become demoralized; begin "poking" at my birds and appearing an absolute "wash out." But this was indeed a pleasant start. I was so bucked up that I was well on the spot all day, and at the end, topped the Rev. Edward's score by one and a half brace! It was "some" shooting I can tell you ; for neither of us let many opportunities pass. All his Reverence said at the count was, "Yes, you can shoot, I give you best !"

The Squire had three grown-up sons. All inherited the family love of sport. At Shardeloes there was an extensive lake which held leviathan pike and other hefty specimens of the finny tribe. I had leave to fish whenever I cared to ask ; but was never lucky enough to have a real good day with Esox lucius; the biggest that ever fell to my rod in those waters being an unconsidered trifle of $6 \frac{1}{2} \mathrm{lbs}$, which happened, by the way, to be the exact weight of the largest trout taken at Missenden Abbey, the lucky angler in that case being my younger brother-in-law, Ronald Barlow, who was very keen on the sport.

The Shardeloes lake was fed, as were the Abbey pools, by the Misburn, and might have teemed with 
heavy trout had the pike been removed and the whole cleared of noxious weeds and the deep mud which had silted to such an extent that the surface water was reduced to less than a third of its normal area, forming a morass, heavily overgrown with rushes, which proved most attractive to wild fowl of many varieties. Here, also, was a sure draw for Mr. Reynard. Many a one have my beauties chevied therefrom to the big woods which unfortunately were far too handy. I seldom killed a fox found in the Shardeloes marsh. At the commencement of my second season, that accursed plague, mange, broke out among the foxes of the near West and far East of the country, and it soon became evident that drastic measures must be taken if the trouble was to be successfully tackled. A great many afflicted cubs were chopped during the educational period, but hounds showed no inclination to break up their victims even had they been allowed to do so, which naturally they were not. Others, marked to ground, were dug out and an end put to their misery; though by way of experiment I bagged a well-grown dog cub which seemed less afflicted than some, gave him a liberal dressing of paraffin, Stockholm tar, and black sulphur, and turned him back in his earth with the idea that he would thus disinfect it. Perhaps he did so; but as it was never again used by any of his tribe, though formerly a favourite refuge, my brain wave did not pan out as well as might be expected. 
One day we got among a litter in a large covert, every one of which was a pitiable sight to behold. A brace was quickly "done in," and then I viewed a miserable little wretch as he crawled into a woodstack. I touched my horn, and when Jack Westrup came up with the terriers, I told him to let Damon and Pythias, two of my most punishing "wire hairs," have a go, knowing that this would settle the poor cub in two shakes of a duck's tail ; but like the assembled hounds they did not seem anxious for the job. One of the field, who always had a fatuous opinion to air, expressed it as his belief that it was a rabbit that had entered the woodstack.

"Not a bit of it," I said. "I viewed him in myself. It was a cub right enough, and a $d-d$ mangy one at that. Why, he had not a hair on his tail!"

"Tail ?" Ah, thought my friend the enemy, I have him on the hop.

"Oh, Master!" he exclaimed, looking round at the congregation in anticipation of triumph. "Tail! fancy you backsliding like that! I did not know that foxes ever owned tails."

"Oh, there are exceptions," I answered unconcernedly. "This one is a case in point. As the poor brute has not a hair on his caudal appendage, it could not by any stretch of imagination be termed a brush."

Great applause from the throng, and the funny one completely disgruntled. 
It was not long before I discovered the source of the plague. A certain covert owner, whose affections were more centred on pheasants than on foxes, had instructed his keeper to dig up a litter of cubs and to rear them in captivity until required. Such a requisition being their transfer, in a bag, to an outlying covert (where there were no pheasants, no rabbits, and no undergrowth, and, consequently, no foxes in statu nature), what time I had fixed a meet in the vicinity. Now this keeper's idea of fostering fox cubs was to enclose them in a covered-in pig-sty, to throw them the decaying legs of horses or cattle that had succumbed to disease, and never by any chance to clean out their improvized den. Finding them minus their natural covering and almost in extremis he liberated them. "Hinc illa lachryma."

Faith, a M.F.H. has much to contend with! Of course this temporary check to what, until then, had been such sport as had not been enjoyed in the old country since the halcyon days of Harvey Coombe, brought all sorts of abuse on my devoted head. Some went so far as to say that I had secretly imported mangy cubs from other hunting countries and so brought about the disaster. Colour was given to this libel because, when I had accounted for all foxes in the localities affected, and had dynamited their earths, I did import some very fine and healthy vixens from the non-hunting wilds of Wales and Scotland, knowing that wherever each should draw her own habitation, a 
clean, outlying dog-fox would be sure to come acourting. And so it turned out. The result was eminently satisfactory, for the following season saw us with a particularly lively and straight-necked stock of red rovers. 


\section{CHAPTER VII}

T $T$ must not be supposed that this outbreak of mange put a stop to hunting, though we had to go further afield for our sport; but the coverts were so large-by the way, the original limits of the O.B.H. were bounded by Hyde Park Corner and Cheltenham-that there was ample scope for sportive investigation. Outlying foxes in the Aylesbury and similar remote districts were "spotted" and located by Jack Westrup and other experts. A by-day would be improvised, and occasionally, we had some topping runs with the vagrants; though, of course, we had some occasional blanks, with no "safe find" to fall back upon.

One of the great blessings of these minor expeditions was that fields were, if select, decidedly small. All "the boys" of our own crowd had "the office," and religiously attended. Good sportsmen and straight riders, who saw to it that foxhounds, and even I, had fair play.

One of these enterprises provided perhaps the best and most exciting run I ever had with hounds. Peter Chutterbuck had sent word to me that an old dog fox had taken up his quarters in the fastnesses of Stanmore 
Common. Already we had had several good runs from this rather suburban gorse, and twice we had been laughed at by probably the same old dodger, but on the last occasion I had tumbled to his tactics and was now prepared to counter them. Ted sent out private notices of a by-day to all the genuine crowd; but not a word to the rank and file of the Hunt. I selected two of my fastest mounts, both real good leppers, to wit, Cinderella- a chestnut mare almost clean bred who had won two nice little steeplechases at Hunt meetings, and Uncle Ben, a bay gelding, bought locally as a four-year-old, and broken to my own hand, after he had had the rough edges chipped off by Bedford, who was a fine horseman, and who delighted in preparing green ones for me to polish. I made up my mind that our artful friend would make tracks at the slightest sign or token of our approach, so I sent Tom Goddard, my first whipper-in, to a point where I figured that His Nibs would sneak away; whilst Wilson posted himself three fields further off, but well in sight of Tom who was not to halloa the fox, but only to signal to the kennel huntsman so that there would be no likelihood of Joshua doubling back.

Hardly had hounds been thrown in than the sonorous voice of old Landsman was heard. This was a Washington hound that never told a lie. All the others of the pack knew it, and would rally to the tongue whenever and wherever thrown; so that the next moment the shrill piping note of Blossom, one of 
the most prominent and determined of my bitches, joined in a duet with Landsman's bass. And then a full, glorious chorus broke out, as the whole pack struck the spot where reynard had curled himself up to dream of poultry yards and vixens. In an incredibly short space of time Wilson's halloa was heard, announcing that the quarry was well away. I thrust Cinderella at the rather trappy and hairy obstacle that divided the common from the open grass. She was always a bit impetuous at the start. She rushed the fence and nearly came down, but she kept her legs and I my seat. I pulled her up and touched the high notes of my horn, a signal which my hounds knew well. Out they streamed, with very few lingerers. Wedlock, one of the Curraghmore bitches, was the first to pick up the line; she threw her head up, striking an exultant and musical note which brought the whole bunch into action. Away they went, heads up, sterns down, at their best driving pace. Ye gods! What a sight to thrill the heart! What a sound to enchant the ear! Forr'ard, forr'ard, forr'ard ee wye! Nothing but grass in front of us, but the clay soil rather holding, so that the canine element had the foot of the equine and its burdens.

The select little field was well away, with the exception of one unfortunate wight who was riding a halfbaked young 'un which turned turtle at the very first fence. Neither colt nor rider was hurt. Having remounted, the latter, I am told, took his mount back 
and put him at the jump again, and this time the young 'un cleared it; but the rider saw no more of the historic run. This was the normal happening when J. B. Cowley was schooling a "rookie." We were a mile ahead, and having to push our mounts to keep the pack in view. As they swung round by Elstree reservoir, about fifteen minutes from the start, I was able to take a short cut with Ted (on his slow but sure old charger, Patrick Geogehan) and several others of the boys. I had the luck to nick in with hounds as they crossed the London road, and set their heads, as well I knew, for Scratch Wood, the scene of many happy days with the gun; for it was situated on the family estate, then in the hands of my half-brother Irwin. My second horseman, George White, was waiting here with Uncle Ben; but Cinderella was still fresh and eager, so I sent my man on by road to the far side of the sixty-acre wood, where I felt certain our fox, finding the drain holt in which he had hoped to harbour himself well stopped, would again face the open and point his mask for Coombe Wood or Shenley. The pack, without the semblance of a check, drove over the two miles to "Scratch" in what must have been record time. Then right through the covert they went, sending my brother's cherished pheasants bustling and squarking in all directions! This meant trouble for me; but there was no time to weigh consequences. A halloa! from White told me I was right in my conjecture as to the itinerary of Joshua. There 
was a momentary check on the road where His Nibs, having cocked an eye on George's buff coat, had doubled on his tracks and then broken across the open again. This gave me time to change on to Uncle Ben, who was very much on his toes. On White's information I halloed the hounds, nipped over the road hedge, and swung the pack in a semi-circle over the field. Trimmer, my show hound, and Wrangler, a son of the immortal Belvoir Weathergauge, struck the line simultaneously and signified the same in the usual manner. Away flew the pack, "Haik to Trimmer, Haik to Wrangler, forr'ard, forr'ard my beauties, push him along-Yoi Blossom! Yoi Wedlock! Yoi Sampson," as each took the lead only to be headed by the next! I was now away with the hounds by myself, and felt exultantly puffed up. How selfish some of us are! I was sorry for the field, though the survivors led by Wilson were well within hail. After seven minutes of glorious galloping and jumping I was faced by an obstacle which I hate and loath like poison, a bull fence, vulgarly known as a " bullfinch." It was set on a rotten bank. I charged it with my arm over my face. Uncle Ben burst half through it then became straddled on the beastly bank, where he remained struggling and see-sawing; what time I quietly slipped off his back and pulled his hindquarters free. But by this time hounds were well out of sight, though I could hear their music in diminuendo in the distance. There was nothing left but to follow 
as best I could. I had not gone far before I became aware of a strange sensation around my right eye, and soon I could not see out of it, but there was no pain. After a time I struck the trail of some of the field, and after jogging along for a mile or so, having lost all idea of topography, I heard a faint " whoop-whoop" from a wood on the hill. Great Scott, they've killed, thought I to myself, cursing my luck for not being in at the death; but as it happened they had not killed. The brave red skin had found sanctuary in South Mimms Wood, and was being marked to ground by Wilson, who had taken command when I disappeared.

The run had lasted fifty minutes, with hardly a breather, and on grass nearly the whole time! As soon as I rode up I was greeted by Wilson with, "What's the matter with your eye, sir?" I did not know ; but it turned out that a long blackthorn had penetrated above the eyelid, though most fortunately without injuring the eye itself. Extraversed blood had caused the whole socket to swell up, entirely destroying, pro tem, its sight. When this thorn was removed, it proved to be three-quarters of an inch long. Luckily nothing worse than a real lovely black eye supervened. Faith, but it was a glorious run! Of course, so gallant a fox was left in peace; but he never visited Stanmore Common or its neighbourhood again, as far as could be ascertained.

We were all mightily pleased with ourselves, but we had to face the reckoning. 
Next day I received a furious letter from my brother Irwin, who upbraided me, in no measured terms, for not having whipped off before entering Scratch Wood, and sending the long tails far and wide over the surrounding country. He said that on the day following our raid, he had fixed up a big shoot in honour of a certain distinguished General, who was his guest, and that now I had upset the whole applecart. Furthermore, he threatened to cut me out of his will (I am his next-of-kin and legal heir), leaving me with a very dilapidated boot to put my foot in. Now, although I place fox-hunting well in front of pheasant shooting, or for the matter of that any other form of sport with the gun, I am not averse from such diversions and enjoy the burning of villainous saltpetre, or its nitric substitute, especially if accompanied by a boon companion, a clever retriever, and a pointer, setter, or tireless spaniel. So that I had some understanding of my brother's wrath. He hated hunting like poison, and, of course, did not understand the difficulties in which I was placed. In the first place it would have been utterly impossible for my whippers-in to get to the head of the pack, screaming and driving full steam ahead on a burning scent. Had there been the semblance of a check I could have lifted them to the far side of the pheasant preserve (as I was confident that the fox would go right through and sink the valley) and have slipped them on to the line. But there was no such check-thank our lucky stars! It was 
some time before Irwin's fury went off the boil and gradually simmered down to a plaintive sibilation. Then ominous growlings and grousings became audible throughout the country; because all subscribers had not been warned of the by-day. A committee meeting was held, and I was solemnly cursed by bell and book; but like the "Jackdaw of Rheims," I felt not a penny the worse! Of course there was reason in the complaint; but it was urged by the neglected ones, for the most part, in a spirit of mere captiousness. These were they who would never have dreamed of attending such a cutting-out expedition, and even had they done so would never have gone two fields from the common. They heard of the great run with envy, hatred, malice, and all uncharitableness; but one thing is certain, if these slackers and shirkers had assembled in force there would have been no such a run. It was only contrived by strategy and tactics of the most meticulous order.

Nevertheless, rebellion was in the air, and the conspirators-chiefly members of the aristocratic committee itself-worked steadily behind my back, with a view to my displacement by a professional huntsman ; though I was to be permitted to retain the mastership and to provide the odd $£ 4000$ per annum (over and above the $£_{1} 200$ subscription) which it cost me to run the show. I soon gave them to understand that under no circumstances would I give up the horn, quoting 
the excellent sport that had been shown, and the record tally of foxes accounted for.

A general meeting of the Hunt was convened. Ted, who was exceedingly popular with the farmers and tradesmen, went a canvassing, and so well did he succeed on my behalf that, when the matter was put to the vote, the committee found themselves in a minority, and forthwith resigned in a body.

Then I did a foolish thing, and not for the first time under similar circumstances. I have always been utterly averse from kicking an enemy when he is down. Given the whip hand I have invariably lowered the lash and soothed the offender. In this case, in addressing the meeting, I thanked it for its vote of confidence, but implored it to restore the now thoroughly disgruntled committee to its former status. This was done, but, as usual, the coals of fire which I had heaped on the heads of my enemies scorched my own hands cruelly. 


\section{CHAPTER VIII}

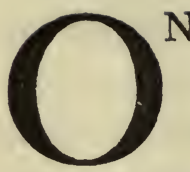

$\mathrm{N}$ leaving Missenden Abbey I had taken a furnished lease of Harefield Grove, near Rickmansworth, for the term of twelve months, the while Chorleywood House, which I had purchased from my fellow clubman, Baily-Ackroyd, was being prepared for occupation. The long disused kennels, situated on the edge of Chorleywood Common, had been renovated and my hounds, horses, and hunt servants were already comfortably established there. There was quite a nice bit of shooting attached to Harefield Grove, a fair show of partridges, and some 300 homebred pheasants, so that when at times that season Jack Frost had placed his veto on hunting, I and my friends were able to indulge in sport with the gun. It was in these comfortable quarters that the second of my three sons (Denis) first saw the light.

As soon as Chorleywood House was ready we migrated there, and our social and domestic life began in earnest. My C.O. was not really a hunting enthusiast. During my Mastership of the Missenden and Hambleden Vale Harriers she had ventured to trust herself on horseback now and then, but one fine I00 
day, being jumped off and deposited rather rudely on the ground, she there and then foreswore the chase and devoted herself to less exciting diversions. Not so her younger sisters "Miriam" and "Freddie." They were as keen as mustard, and a particularly smart couple of worshippers at Diana's shrine. Both were fearless horsewomen with perfect hands and stout hearts. So far all had gone well-the clouds were already gathering, but it was some time before the storm burst as narrated in the preceding chapter.

The fact that I had been supported by " oi polloi" to the detriment of the committee's amour propre, undoubtedly rankled; so I began to feel that I held an isolated and far from secure position. It might have been imagined that the committee of the O.B.H. having been re-installed at my earnest request, after its defeat by the body of subscribers, would have had the decency to acknowledge the courtesy by refraining from further back-biting and grumbling; but alas! such was not the case. On the contrary, I soon found myself up against a carping spirit which took all the steel and enthusiasm out of my endeavour to keep up an average of sport such as had not been enjoyed in the country for very many seasons under previous masters. Consequently I began to feel utterly weary and fed up ; so that when another general meeting was convened, like Brer Rabbit I just "lay low," and offered no opposition to a suggestion put forward by a certain noble lord, whose suavity was 
obvious, but whose loyalty and sincerity were open to doubt. His lordship paid me most lavish compliments, but insinuated that in his opinion I had bitten off more than I could chew in trying to hunt the whole country successfully. He then begged to move that the said country should be again divided into East and West ; that I, with a certain proviso, should be graciously permitted to deal with the East ; whilst Squire Drake's cousin, Capt. "Mutey" of that ilk, should take over the mastership of the West, as previously hunted by Austen Mackenzie.

Some one got on his hind legs to ask what the proviso might be, and was informed that it was that I should allow my kennel huntsman - at that time Jack Abel-to carry the horn on alternate hunting days. Now under normal circumstances I should have fought this motion tooth and nail, but by this time clouds were gathering over my domestic roof ; moreover, I was becoming so keen on race riding that I must confess that on many occasions I had put Ted Jaquet in supreme command-with Abel to hunt the hounds-what time I had donned my colours and was desporting myself, more or less successfully, at Kempton, Sandown, Hurst Park, and other arenas over which " blood" bounds.

This gave an excellent-and, I must admit, legitimate-handle for the opposition to use against me. That it did so with a hearty will and hefty pull I need hardly say. So I agreed to the terms, and made 
the best of them during what proved to be my last season, which was only conspicuous by reason of the great physical merit of the young entry, and the consequent raising of the whole pack to a quite high-class level, from a purely show point of view. Otherwise there was a lamentable fizzle. We were short of foxes, and the hounds, being unable to serve two masters, became bewildered, and lacking in the dash and perseverance which had erstwhile distinguished them. It was a sorry business.

I wonder how many earnest and striving M.F.H.'s have had their hearts and spirits broken as I had, by the lack of sympathy, understanding, and true sportsmanship on the part of their committees; their name is legion, I trow. Of course, there were one or two of the right sort who were members of mine, but they were in a marked minority and quite overshadowed by the "Big Noises" who held their position by the virtue of their social status in the country, but who seldom, if ever, deigned to attend a meet, or if they did so, drifted away after, say, the first adjacent covert had been drawn. And yet they constituted themselves arbiters of my efficiency, or the want of it, and never hesitated to advance their academic theories whenever occasion gave them the opportunity. But one striking exception was the Hon. Secretary, to whom I owed a great debt of gratitude. His post was almost as thankless a one as my own, but he cheerily carried on and weathered all storms by his tact and amiability. I 
am not alluding to my own private secretary and bosom pal, Ted Jaquet, who, as stated, acted as Field Master, and who was so appointed by myself, but to Harvey Fellowes, who in his day had been a member of the All England Cricket XI, in company with dear old "Uncle Punch" Burbidge, and who was, so the latter declared, one of the fastest and deadliest bowlers he had ever seen.

Misfortunes seldom befall in single spies, but generally descend in battalions, for it was at this juncture that the props of my home were swept away by a devastating cataclysm, and for years to come I was plunged into a legal and psychological turmoil which completely diverted the current of my hitherto happygo-lucky life.

On this miserable phase of my existence I have no wish to dwell. Sufficient to state that circumstances compelled me to take action for divorce against my wife, and that, as the lawyers on either side were intent on plucking the pigeon to the last feather, the proceedings were painfully protracted for over three years before a final issue was arrived at.

Naturally enough, the matter was a public scandal, and afforded food for every gossiping lip ; so that my position as M.F.H. became untenable. Both my domestic and my sporting establishments were broken up. I sold my home and estate to the Duke of Bedford, whilst my hounds and horses came under hammer. 
It was a heart-breaking day for me when the auction was held. I studiously absented myself. I could not bear to see my beauties paraded in couples and knocked down to strangers. The only consolation and sop to my pride which was vouchsafed me, was that they were so thoroughly appreciated by leading masters and houndmen that the prices obtained spoke eloquently of the success that had attended my activities and my endeavours to produce a first-class pack in record time. One of my stallion hounds, which had been an exceptionally brilliant worker and an exceedingly handsome specimen of his race, was purchased by Chandos Pole, who used him to such effect that, two seasons later, he had no less than twelve and a half couples in his entry owning this hound as sire. This was Sampson, by Brocklesby Weathergauge, a son of Belvoir Weathergauge. Trimmer, a rich tan son of the last named, and one of the grandest hounds I ever owned, went to the Devon and Somerset Staghounds, where he soon asserted his transcendent merit ; but he met his death in strange fashion. A hunted stag had taken to a mill pool, the wheel of which was in ply. Trimmer, who had led the pack from the start, leapt without hesitation upon the revolving wheel, only to be dashed, stunned and broken, into the pool below. When taken out he was quite dead. Alas, poor Trimmer!

It had always been intensely interesting to me to study the characters and idiosyncrasies of every hound in my pack. None impressed me more than that of 
Landsman, to whom I have already alluded. He was a fine, powerful fellow, but lacking in quality from a Peterborough point of view - by the way, I only judged at the great hound show once, and then I was told off to deal, not with foxhounds, but with harriers and beagles. His was rather a surly disposition. $\mathrm{He}$ would grumble and grouse, with hackles erect, every time he was drawn, and it was some time before I got the right side of him ; but once attached, he was quite devoted, in his own peculiar way. In the field, he was the beau ideal of the perfect foxhound; though some of the fliers of the pack could lead him on a burning scent, he was absolutely reliable. When Landsman spoke the word, its truth was recognized by huntsman and all who knew him. The greenest puppy would fly to it in covert. "Haik to Landsman!" was a sure signal that reynard was afoot. During a run, and when a check had occurred, the same cry was an assurance that the true line had been recovered. $\mathrm{He}$ would face anything, and go right through the thickest gorse or undergrowth, fire or water, and over the highest palings. $\mathrm{He}$ would have faced the devil himself. He always drove with those bristling hackles up, and as the pack ran from scent to view, I have seen him dash out, course the unlucky varmint as a greyhound does a hare, bowl him over single-handed, and shake the life out of him as a terrier does a rat! Faithful old fellow! He was the "Daddy" of the kennel at home or in the field for three seasons; but then he 
lost pace, his hackles lay smooth on his neck, and he would tail off sadly. But when there was a check or scent began to weaken, he was there to set the clock right.

I have forgotten to mention that, during my last two seasons, Jack Abel had taken Wilson's place as kennel huntsman, the latter having been appointed huntsman to the Bicester under the mastership of Lord Chesham.

Abel had on several occasions commented on Landsman's failing prowess. One day I missed the dear old hound. "Where's Landsman ?" I inquired, as I cast my eye over the dog pack at the meet. "Better not ask, sir," replied Jack grimly. I took the hint, but felt very sad. Of course, if Landsman had been a normal hound I would have kept him as a stallion; but he was not. He had the appearance of a gelding, but had been so born, not made. He could perform amorous gymnastics, but there was never any result. In this he resembled Fullerton, to my mind the greatest greyhound of all time, and certainly the most brilliant I ever saw run.

After my resignation, Bob Webber took on the O.B.H. East, and hunted it for many seasons with great success. In the West, "Mutey" Drake did well, but did not hold on long. He was followed in turn by "Bobby" Leadbetter and Alfred Gilbey, good friends of mine; but I have no precise information as to the sport they respectively showed. 
During my hunting of the whole O.B.H. country an incident occurred which was eloquent of a sad tragedy. I had found a fox in the great straggling coverts which lie between Gerrard's Cross and Beaconsfield. After a long, slow, and intricate run on a "catchy" scent and over very rough going, we marked him to ground on the steep " hanging " below Cleveden. It was late in the day and the shadows were lengthening every minute. It was no good leaving "Joshua" in his retreat, so I gave some local rustics orders to unearth him, gently transfer him to a sack if and when possible, and report to me in due course, when shekels would be handed out as a reward for their enterprise. Now it seems that after a couple of hours' strenuous labour, carried on by lantern-light, the diggers came upon a hollow cavity wherein was found a heap of bones and skulls. At first it was thought that these grim relics were the result of the larceny and raiding of a super-fox among the sheep folds; but honest John Westrup, who had stayed to superintend operations, was seized with a brain wave. He remembered that some twenty years previously, the hounds then hunting the country had run riot and had gone clean away from master and hunt servants, with a fox heading for the heights that overhang Father Thames between Taplow and Cookham. When the pack was eventually held up late at night it was discovered that five and a half couples were missing. Expecting these to find their way back to kennel, or that they would 
be harboured and tended by dwellers within the hunt, there was no grave anxiety at the moment; but when days passed and no sign or news of the missing hounds was forthcoming, advertisements and notices were issued, offering a handsome reward for their recovery. Nothing happened. The five and a half couples seemed to have vanished into thin air, or to have been swallowed up by the earth. Ah! the alternative gave Jack the hint. He counted the skulls. Yes, there were exactly eleven of the grisly frontispieces. "Why!" he exclaimed, "I'm darned if these ain't the hounds what was lost twenty years agone!" And undoubtedly he was right. These poor creatures had evidently squeezed themselves into the wide opening of the earth in pursuit of the quarry and had, one by one, congregated in the little cavity. Then the chalky soil had probably fallen behind them completely blocking them in. They had torn and scratched in their vain attempt to find a means of egress, but had only succeeded in enlarging the death chamber. It is to be hoped that suffocation brought a more merciful and speedier end than stark starvation; but anyway, the tragedy, as reconstructed, is a pitiful one. 


\section{CHAPTER IX}

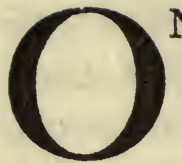

$\mathrm{NE}$ evening-after dinner, be it noted-I was boasting vain-gloriously of the love my hounds bore me, and how they would recognize me anywhere and at any time, even if I were not arrayed in my hunting kit or a kennel coat.

A certain sportive guest, who would wager on anything and to any amount, broke in-

" Here, old Cockie, I'll bet you you won't go down to the kennels here and now, just as you are, boiled shirt, dinner-jacket and all, walk right into the dormitory department, and sit down for ten minutes among your docile beauties without uttering word or sound."

"Done with you. Why not?"

Here the discreet and watchful Ted broke in.

"Don't be a fool, Cockie! No matter how devoted our-note the possessive plural-hounds, a sudden rush and scrimmage would probably occur; you might slip, and then some fool hound would be sure to set about you viciously. Once 'the worry' commenced you would have the whole pack at you and 


\section{CHASING AND RACING}

you would be broken up before help could arrive or the hounds realize their mistake. Remember 'Uncle Punch's ' yarn about the master who kept chickens in the loft over his kennels."

"What was that, Ted?" from a chorus of hilarious voices.

"Why," continued my cousin, " although his hens cackled regularly and continuously, devil an egg did their owner gather. Naturally he suspected deliberate larceny, so he lifted the lid of the trap-door which was plumb above the sleeping kennel, and substituted a square of thick brown paper, which he covered with light wisps of hay. In the morning he was enriched by a dozen new-laid eggs, and in the kennel was found a pair of boots! The hounds refused to answer to "Yoi cess cess!"

But this fearsome tale of tragedy failed to overawe me.

"It's a challenge," I replied. " He has dared me, and bet upon it. I'm on, and chance the ducks. 'If 'twere done, when 'twere done, 'twere well 'twere done quickly.' So come along. Here goes!"

Suiting action to words I arose and picked up my cloth shooting cap.

"Well, Cockie," said Ted, shaking his head mournfully, " at least I-note the first person singular(very !)-insist on one condition. We must all accompany you armed with whips, and stand by when you enter the kennel, in case of accidents." 
" All right, old friend, so long as you keep at a respectful distance."

So we sallied forth. A full moon was shedding her radiance on the bosky gorse which covered the common leading to the kennels. As we passed the gates of the demesne the mournful song of the hounds, paying tribute to their goddess Diana, rose and fell on the fitful breeze. The chorus was answered in counterpoint by the lugubrious hoot of a vagrant owl. It was bitterly cold. The exhilarating effect of Pol Roger, I889, topped by a liqueur of fine champagne of the Napoleonic era, was beginning to wear off.

Was I obsessed by funk? I hardly know; but certainly I was not quite as cock-a-whoop as erstwhile I had been when comfortably ensconced in my favourite armchair before the fire in my smoking-room.

A similar eerie feeling seemed to have overcome my friends, for there was an ominous silence as we neared the scene of action.

On arriving we had to knock up Wilson and his satellites in order to inform him of our purpose. He also was loud in his endeavours to dissuade me from my foolhardy escapade.

"Don't ye do it, sir. Gawd knows what may happen. Why, I would not take the risk for a mint of gold or the pick of the stable. That old Landsman would be at you like a tiger before he tumbled to it you were the master!" 
But my foot was obstinately set one way, and I did not mean to budge an inch.

The others stood back as I entered the outer yard. Then quietly I approached the sleeping quarters and noiselessly lifting the latch slipped in.

The moonlight fell aslant the flags; all was still. The pack, having finished their evensong, now lay coiled up in peaceful slumber, huddled together for warmth.

For fully two minutes I stood there, stock still and as silent as the grave, but my heart was rapping my ribs uncomfortably. Then a single hound raised his head. It was the surly and ferocious Landsman.

Slowly he came to his feet, gazing intently at the mysterious and silent figure before him. Then his hackles began to rise "like quills upon the fretful porcupine," but he uttered no sound.

All of a sudden, Blossom, a bitch whose love for me was as that of a Juliet for her Romeo, or a Francesca for her Paolo, awakening from her dreams (maybe, of straight-necked foxes, and the glorious odour of a burning scent), sniffed the air, and then bounded to me with joyful whines. In an instant the whole pack, including the crusty Landsman, was in action, and so to speak, all over me, lavishing their caresses unrestrainedly. Then I sat on the bench, and when my friends, with the wind well up, came rushing in by reason of the rumpus, I had one arm around the grumpy old Landsman's neck and the other around 
Blossom's. I had a to-do to restrain my beauties from giving my guests a welcome of a very different kind, for they, the hounds, evidently imagined that a vigorous offensive was being launched against the person of their master.

And so I triumphed, but for a moment it was touch and go. Had Landsman made an aggressive spring, there is no saying what my fate might have been. It does not bear thinking of. Against my will I have had at times nasty nightmares, induced by a subconscious realization of my peril, and have awakened in a cold sweat. As it was, I suffered no injury whatever-which is more than can be said of my boiled shirt and dinner jacket. I established my contention and pocketed a fiver, though that magnificent sum could hardly be termed " easy money."

I once wrote some verses for the purpose of recitation, describing how a postman of the moors had been hunted by Lord Wolverton's bloodhounds.

He had helped the huntsmen to get the stag out of the river, and held it whilst the knife did its deadly work. Subsequently the hounds, a very wild and irresponsible lot, ran riot, and getting on the line of the unfortunate letter-carrier, gave him a time of acute terror. In fact, he only just saved his skin by shinning up a solitary but friendly tree. The final lines of the piece ran-

I lay in the fork the livelong night

And when they found me my hair was white,

So now you know all about it ! 
This trifle was founded on fact. It is not often that a M.F.H. is hunted by his own hounds; but this happened to me.

We had been to an outlying position of the East Division of the country, and as I had an important public banquet to attend in London, I decided to go with Bedford to the nearest L. \& N. W. stationwhich was about three miles from the point where we had whipped off for the day-and book direct for town, sending the pack back to kennel with Jack Abel and his trusty men.

I and my horseman-valet jogged along, but from the ratings and whip-crackings we heard in our rear, it was obvious that the little ladies-for it was the bitch pack that had been drawn for the occasionwere giving trouble in their desire to accompany me.

All went well, however, until we were about a quarter of a mile from the station. We then became aware of most astonishing happenings. The pack was in full cry, but the key of its tongue had a most unaccustomed tone. As an accompaniment, human voices, uttering curses loud and deep, were to be heard, with an obligato of cracking whips, which went off like pistol shots. Then, round the corner of the road, some five hundred yards to our rear, poured the beauties, going hell-for-leather, with the hunt servants vainly endeavouring to get to their heads. In less than a minute they were up, and all over me and my horse-the latter was the true and tried Melbury 
who, being accustomed to these ebullitions, suffered hounds to swarm around him and even jump at his head and quarters, without the remotest sign of irritation. A bitch called Sensitive, noted for her agility, actually leaped on to the pommel of my saddle and hung on. I dismounted, and handing Melbury over to Bedford, I took the now thoroughly exhilarated pack aside, so that it could be ringed in and commanded by "the boys in yellow." Then I slipped back and remounted. All to no purpose. The little ladies broke the siege and again clustered around me. It was a delicate task for the whippers-in to flick them away without giving me or my mount a taste of the lash. Rhoda, Blossom, her sister Beauty, and Speedy, a Curraghmore bitch, absolutely refused to budge, and kept dodging in and out of Melbury's hoofs with their sterns down and their hackles erect. Jack Abel sat mopping his brow and cursing under his breath, whilst Tom Goddard grinned fatuously. My heart went out to these faithful creatures. Visions of a gargantuan feast and the wine when it is bubbly, faded into nothingness. Instructing Bedford to send a telegram from the nearest Post Office, I wheeled Melbury round, and touching the horn lightly, turned his head towards the kennels, seven miles distant, with the bitches, their sterns now up and waving triumphantly, in peaceful and orderly attendance.

Like most of those who go out to the hunt on horses, I have occasionally indulged in a busman's 
holiday. Sometimes my good friend, Lord Lonsdale, would invite me to Brigstock to make acquaintance with the Woodland Pytchley. Together with that sportive personality known to his intimates as " Rock" -being an abbreviation of his courtesy title, Lord Rocksavage, subsequently to become Marquis of Cholmondeley - and Lord Burghersh, afterwards Earl of Westmorland, we set out for a round, which included the Fitzwilliam and Bache Cunard's.

It was when enjoying a day with the latter that Major Candy-commonly called "Sugar "-was much scandalized because of the contraption which I had affixed to my saddle to prevent my being jumped off ; for at that time I was suffering from.a severe strain of the tailor's (sartorius) muscle in my left leg, which prevented me exercising an efficient grip. I may here remark that this same trouble lasted me some years, and even when race riding caused me to assume such an awkward and lop-sided seat that I became the target for the slings and arrows of outrageous jocularitygood-natured when I won, and otherwise when the slinger or archer had backed one of my mounts which had failed to catch the judge's eye.

But to return to "Sugar" Candy. We partook of luncheon one day at his shooting-box, and here I met his only daughter "Kitty," destined to become Duchess of Newcastle, one of the most successful breeders and most competent of judges of wire-haired fox terriers that ever lived. From her original stock 
and her great sire Cackler of Notts are descended nearly every terrier of the breed that is entitled to the prefix "Champion."

Another time, Lord Lonsdale informed me that Henry Chaplin had lent him his Lincolnshire residence, Blankney Castle, for a space, and suggested that I should accompany him thither. Here it was that I had the interesting experience of feasting my eyes on Hermit, the sensational Derby winner of 1867. The little chestnut was then in the sere and yellow, and looked rather sorry for himself. He may not have been among Derby winners of the very highest class, but, as all breeders know, his success at the stud was phenomenal. His blood runs through that of a very large percentage of subsequent winners of the "race of races."

Whilst I was at Blankney, Jack Frost made his objectionable breath felt, and snow lay deep on the ground. We poached some of our host's pheasants, and tried in vain to course his hares; but we had to give it up and await a more favourable opportunity. This came when the Lord of Lowther Castle took over the Mastership of the Blankney, and invited me up to sample the sport. I brought Yeoman and Uncle Ben with me, and all and sundry were curious to see how these nags would negotiate the local stone walls, neither they nor their rider having had any previous experience of this style of "lepping," but I don't think we disgraced ourselves very obviously. 
It was whilst hunting with another pack-my neighbour the Hertfordshire-that I nearly came to an untimely end. I was riding a "bit of blood" called The Fairy. She could gallop to a pretty tune, and was a big and fearless fencer. With my light weight she had the foot of the field, when hounds were on the stretch. They swept over a small paddock, bounded by a rather formidable fence, with such a big drop that I could not, until I was in the air, see one of the field, who had taken a short cut and was trying to butt in and take an unfair advantage. My filly landed right across the quarters of the other nag, so that all four of us played roly poly together in a regular " mix up." I felt the cantle of Fairy's saddle grind right over my neck, which, luckily for my future, failed to snap under the pressure, nor was the other rider or his horse knocked out. We were soon going again. Crossing a thirty-acre field there were two flights of sheep hurdles to negotiate. The first I flew comfortably enough, and then, to my horror, I went stone blind. However, I stuck on, and my filly took me over the second flight all right. Gradually my sight returned. At first I could only see a pin's point of light, but this widened until I seemed as if I were looking through binoculars. Finally, normal vision asserted itself, and I went on happily enough, to enjoy a real good run, which ended in the fox being marked to ground. Whilst giving my filly a well-earned breather, the young fellow-my-lad who had got in my 
way ranged up alongside, and in a dulcet and sympathetic voice, inquired if I was hurt. "Oh no, thanks," I said genially, " not a bit. I'm quite all right!" Then, to my utter astonishment, his tone changed completely, and he ferociously remarked, "Then you ought to be! It would have served you d-d well right if you had been killed!"

I was so taken aback that I was struck dumb, and my usually ready tongue failed altogether to frame a repartee.

On the way home Ted and I, with one or two other choice spirits, called at a wayside inn and regaled ourselves with a right royal repast. When I retired to bed I felt as fit as the proverbial fiddle, and on the best terms with myself; but when I awoke in the morning I was in agony! I could not move my head the fraction of an inch, and I ached in every limb. I felt on the verge of paralysis, and when my C.O. called in the doctor, I was informed that my neck was broken as near as makes no matter. After he had strapped and plastered me up I had to remain utterly quiescent for more than a week. This gave me an opportunity to think what I ought to have said to the young upstart who, after being where he had no right to be, and so imperilling that which I chose to regard as my valuable life, added insult to injury by informing me that, according to my deserts, that same valuable life should have been extinguished! Thank you kindly, good sir!

This little shake-up was the worst that ever befell me, 


\section{CHASING AND RACING}

either on the hunting field, racecourse, or during my cavalry experiences, but I never had the misfortune to sustain a fracture of any kind. I suppose I ought to knock wood. I may yet be induced to take a chance mount, and once again to catch hold of my horse's mouth and set him going, as the cheery "view halloa" is followed by the most glorious chorus that ever greeted ears attuned to the symphony.

Quién sabe? Who knows? 


\section{CHAPTER X}

T $T$ has been ever one of my cardinal errors to amuse myself by placing a variety of irons in the fires of life. My friends tell me that had I concentrated my attention on one piece of metal at a time, it would have glowed with a far more luminous radiance than do my bunch of ill-assorted scraps. Unfortunately I have a kink in my psychological composition which forbids any such monopoly. I must needs have a finger in every pie that is baked in the "field" oven. Thus it happened that whilst I should have been entirely absorbed in the occupation of breeding, entering, and hunting hounds, and incidentally kow-towing to the mighty who contributed a mite towards the exchequer, I was prone to devote a considerable amount of time and much cogitation not only to race riding and a study of all matters connected with the turf, but to coursing, angling, shooting, and breeding, training and exhibiting dogs of various sporting and non-sporting kinds, and judging the same at all the leading shows.

As I have already explained, my pony-racing days overlapped my experience as M.H. and afterwards as 
M.F.H. It was, however, during the latter that I ran my first horse in a "legitimate" race. One day, Jesse Winfield asked me if I would like to see my colours carried triumphantly under N.H. rules. Having notified, in a half-hearted way, that I was willing, my trainer of ponies went on to say that he had picked up an ancient crock which, thanks to the application of his remarkable embrocation, had been rendered sound enough to stand a gallop or two.

"You can have him for a song, Capting, and enter him for an overnight selling hurdle race at Kempton. If he doesn't break down he will win. Then you can let him go, for he won't stand another race. It's worth a gamble. What do you say ?"

"Right O! Go ahead! And now, pray what is this decrepit but possibly brilliant steed that you have got hold of Jesse?"

"What do you say to a Chester Cup winner, Capting ?"

"Rats!"

"Honest truth. It's The Reefer, who annexed the Cup and the cheese in $1879 . " *$

Sure enough, the old fellow managed to stand up, and scored quite comfortably. Needless to say, I did not buy him in, nor have I any idea what his subsequent career may have been; but it was something to have made good with my first venture under "Rules," and to have owned-even though

* Seven years previous to this conversation. 
for the occasion only-the winner of such a timehonoured race as "The Chester Cup."

Thereby I was encouraged to continue. I mapped out for myself a pretty little "itinerary pro forma," which should see me riding and winning in hunters' flat races, as at that time introduced to most of the N.H. cards at the principal meetings. My first opportunity occurred when the horses belonging to the eccentric and irresponsible, but kind-hearted Marquis of Ailesbury were dispersed. Among them was a mare called Lady Frederick, who had won one of these events and had run second in another. She fell to my bid at a reasonable figure. Not having any No. I full-sized tackle to try her out with, I gave her a spin at Kempton Park with my champion galloway Catona, whom I believed to be capable of tackling this class of gee, despite her lack of inches. Tommy Aldridge had a leg up on the "pony," whilst I had my first ride on the "big 'un." Sure enough, the gallant Catona (in receipt of a stone) held my mount for speed; but at the distance-the trial was over the orthodox two miles-I got on terms, and won without having to call on Lady Frederick for an extra effort.

This seemed to me good enough, so I entered her at Sandown. Meanwhile, I had registered new colours under rules, viz. "Lemon, orange sleeves and cap," and having donned these, I was thrown up on my new purchase. History repeated itself. As on the occasion of my first pony race at Hurlingham, I was left at the 
fall of the flag. Just think of it, in a two-mile race, started by a flag! I lost five or six lengths, but that ought not to have stopped my mount winning had she and I been good enough. Perhaps neither of us were. Anyway, we had an excellent view of the race all the way from a conspicuous position in the rear !

This was discouraging, but after a bit I began to look about me for something which would do me greater credit. The difficulty was that in those days "Squire Abingdon" (George Baird) was buying up anything going which he considered capable of giving him a winning ride. George had a big capital to draw upon, whereas my fortune, such as it was, was represented by income only, which I could neither anticipate nor charge on pain of forfeiture. Consequently whenever I tried to get hold of a decent bit of winning gee-flesh, Abingdon would butt in and outbid me. But one day at Kempton I did have a look in, when neither "The Squire" nor his agents happened to be on the spot. The usual selling hunter's flat race was the last event of the day, there being about seven runners. The field had not gone half a mile before I noticed one horse, right out by itself, leading by quite a dozen lengths. I looked at my card and found that the "speed merchant" was one Weasel, whose in and out running had caused him to be regarded as one of the "cut and not come again" brigade. But now he kept up steam until the straight was reached. Then he began to drop anchor, though when tackled by one, 
Gladstone, he struggled on gamely enough to win by a head. His name should have been changed to Dizzy!

"I'm off to bid for that joker," I said to a racing pal who was with me.

"Don't you !" he admonished. "Why, old Weasel is the biggest thief of his class, which is saying a lot."

Well, I had my doubts. I had taken quite a different and novel view of the race and the character of the winner.

There were few buyers about, and as the Weasel's "connections" did not seem anxious to retain him, he was knocked down to me for a trifling matter of $£_{12} 2$, or thereabouts.

I thereupon handed my new purchase to James Prince, who, with his brother John, was turning out more winners in this particular line of business than any of their contemporaries. Already he had a filly of mine which I had obtained under rather peculiar circumstances. I happened to be attending a sale at Tattersall's, Albert Gate, where I was on the look-out for a likely nag or two to carry my hunt servants. Presently a small but symmetrical " bit of blood " was brought before the rostrum. Glancing at the catalogue I saw that the "lot" was described as "A b. or br. f. 2 yrs., by Laureate-Clianthus, by Stockwell, untried." Although at that time my pony-racing days had practically come to an end I could not resist bidding for 
this one, since, from what I could judge, she would probably pass under the I 4.2 standard even in a year's time. She was knocked down to me for twenty-one guineas, and I sent her to the brothers Prince, who soon informed me that the little filly could gallop more than a bit. By the time she was a three-year-old she had grown beyond the galloway limit, though still small. When tried, she proved herself smart enough to win a nice little race, and what is more, she " clicked" first time out at "Ally Pally" at a nice price. The "Frying Pan Course"-twice round and once up the handle-seemed to suit her, for subsequently she won another race there, besides picking up some of the spoils elsewhere. At last her merits became so appreciated that I was unable to buy her in, after winning a good-class selling race. She was bought for a Belgian owner, who proceeded to run up a sequence of wins with her, culminating in the capture of one of the most important races in his country. I do not know what her end was. She should have been a most successful matron. Many of these diminutive mares, like their human prototypes, beget hefty stock above the normal size. I forgot to say that I named this smart little lady Guinevere. Her sire, Laureate, was by Rosicrucian-Laura by Petrarch. Her dam, Clianthus by Stockwell. Good enough, in all conscience!

She was the first of my winners under J.C. Rules, and so marked the beginning of a distinct era in my 
racing activities. At the close of her three-year-old season on the flat I put her over the sticks. She took to the game with spirit and aplomb, and I had visions of pulling off something big in this direction. I ran her in two handicaps, one at Kempton and the other at Sandown. In each instance she was handled for me by Roddy Owen, most accomplished of horsemen and best of good chaps, with a similar result, viz., after looking all over a winner two hurdles from home, as she began to weaken, she found the final obstacles too much for her stride, and so nearly came to grief.

"This is a real nice little filly, Cockie," said Roddy; "a brilliant fencer, and dead game; but she is too small for the game. She has to waste all her steam in jumping instead of striding over the sticks. If I were you I should cut this stuff out and keep her to the flat."

Of course, I took his sensible advice. 


\section{CHAPTER XI}

T HAVE now arrived at a point in these " rambling reminiscences" where I must take pause to survey the situation and cogitate carefully. Many of the happenings with which I would deal have been previously chronicled by my pen in various contemporary publications. I put it to myself that the most convenient method for me to adopt would be to quote liberally and almost verbatim from some of these scripts. As one alternative, I could rewrite the items with which I am disposed to deal. This would resolve itself into a question of word-juggling and paraphrasing such as would result in a labour of supererogation, which could have no value from either a literary or an informative point of view. A second alternative would be to cut out altogether the incidents with which I have dealt in other pages. This would, of course, create a hiatus and a vacuum which would have to be filled up with "padding" and extraneous matter of doubtful concern to readers who haply might have been mildly interested in this unconsidered trifle in the way of Turf history in general, and my own experiences in particular. 
The said incidents have been set forth chiefly in The Sporting Life and The Sunday Sportsman. Perhaps they have been read, with ephemeral interest, by the public; perhaps they have been merely skimmed. In any case the journals would be almost invariably cast aside, and these articles clean forgotten. But their inclusion, in part, in the present volume might render them permanent publicity. So now I put to myself the original proposition. "Those in favour thereof, please signify the same in the usual manner. On the contrary? Carried, nem con."

So off I go again !

Hark back to Weasel !

It was not long before I had cheery news from James Prince concerning the progress of my new purchase. He had acquitted himself right nobly in a trial with one Hugger Mugger, belonging to Harry Roberts (H. R. Johnson), who, with his friend and confederate Harry Heasman, were stout supporters of the "Princely" establishment at Lewes. I may here place on record that these two were good sportsmen, ever ready to lend me a trial horse, or to " give me the office" when one of theirs was the goods.

Prince advised the entry of Weasel in "a seller" at Windsor, and so it happened that one fine afternoon found me in the paddock on the Royal Meads, arrayed in the new colours which I had adopted- "Eau de nil (satin) jacket, Mousse green (velvet) cap, and braid "having weighed out for Weasel, and now awaiting the 
order to mount; all the time suffering the prick of "the needle." Once in the saddle my qualms abated and I felt quite comfortable. Now I had not had an opportunity of riding my nag at exercise, for at that time I was Master of the Old Berkeley Foxhounds, and as I hunted my pack myself five days a fortnight, and had other activities in between, I had no time for voyages of discovery to Lewes. So here was I, taking a leap in the dark-riding my second race in "the legitimate game" on a horse I had never previously bestridden.

The only thing to do was to seek my trainer's advice and stand by it.

"This is a nice little horse, sir," said the worthy James. "His temper and manners are perfect, and he will give you a comfortable ride. He may make a pretence of pulling at first. If so, don't saw at him, but allow him to settle down and then take a pull. Lay well up, but don't come along with him until you are half-way up the straight. I think you will win."

Going to the post, Weasel displayed the manners of a child's park hack, and stood quietly at the post. Jimmy Duke was riding one of his own, called Hyacinth, and she was favourite. "Abingdon's" mount being also strongly supported.

"Save a pony ?" I asked the young baronet (Duke).

"Go to h_! !" was his curt and uncompromising reply.

I did as I was told-as regards the riding of the 
Weasel, not, of course, in compliance with Duke's order. My old fellow caught hold of the bit as soon as the flag fell ; but I had him well in hand by the time the junction of the courses was reached, and soon held him nicely placed on the rails, lying fourth, just behind "The Squire." As we completed the circuit and came into the straight I felt my mount going very strongly and smoothly. Half-way up, that accomplished amateur Abingdon took up the running ; but as soon as I challenged, his gee was done with, and I won rather easily by a length and a half. From first to last I did not see Jimmy Duke and his fragrant Hyacinth.

This was a good start. I was immensely pleased with the Weasel, who, I discovered, was at one time something of a celebrity across the Irish Channel, having won the Irish Grand Military and other important jump races; but he had apparently forgotten the art of "lepping," for when I tried him over hurdles at home he proved a very sticky jumper, always showing great caution on the "safety first" principle, by having a good look at each obstacle before attempting to negotiate it.

My second venture on Weasel was a cushy job. It was at Kempton where again " Jimmy" Duke threw down the gauntlet. This time with Unripe-well named, as the issue proved. Although he was a raging favourite Weasel slammed him all ends up, and lobbed home some twenty lengths to the good. There 
was a third runner, steered by Charlie Thompson, known to his familiars as "Bonnety Bob," but no one took any heed of him. I have not the least idea what became of him in the back stretch. I think he strayed out on an ornithological or entomological venture.

Next morning I was "for it" again, because forsooth, when "strolling home" on Weasel, and reaching the line of coaches, my eye fell on an entrancing little golden-haired fairy, of some five summers, who was on the box seat of one of them, with her dad. I suppose she had backed Weasel for a box of chocolates with some fatuous admirer; anyway she waved and kissed her little hand to me as I came by, whereupon I committed the awful solecism of returning the greeting. The Press was very severe, "Buffoon" being the mildest term applied to my inopportune gallantry.

$A$ propos "Bonnety Bob," he was one of the toughest propositions I ever came across. He would ride anything, for any one, at any time. He seldom won a flat race, but that did not trouble him in the least. I remember entering one of my hunters in a steeplechase at the Aylesbury Hunt Meeting just as a fill-up. Cossack was its name, a fair performer in the hunting field, but with no pretensions to negotiating the stiff fences of the Aylesbury course. Besides, he was not half trained. However, Charlie Thompson begged me to give him a ride, and although I demurred 
to being an accessory before the fact to suicide, which is a criminal offence, he would not be denied. I knew he would come to grief at the first fence, as, in fact, he did. Both he and Cossack were playing "Waltz me round, Willie," among the buttercups and daisies in a flash ; but both came up smiling, and had a go at the next fence, with like results. After that they gave it up as a bad job.

"Bonnety Bob" expressed himself delighted with his ride; whilst I was greatly relieved that nothing worse than bruises and strains had supervened.

For some time Weasel continued his triumphant career, and soon became a sort of public character ; but he met his Waterloo at Northampton. He was not so much to blame as his rider. The fact of the matter is that I was over confident when rounding the bend for home. The old chap was full of running, and so, forgetting what a long, flat "run in " it is, on the boot town course, I left the other six runners too soon, and shot some four lengths ahead. Then Weasel ceased pulling, and proceeded to lob. Stupidly I fell in with his views, and made no effort to keep up full pressure. Only one of the others struggled on, a slow plodder, which gradually overtook us, and, before I could get a real move on again, swept by to win by a length. I was rightly slated for my carelessness ; but I have seen professional jockeys, who should have known better, caught napping in this way, times without number. On one such occasion I was a sorry 
sufferer myself. I had a little horse called Armada * in the Great Metropolitan. He had won the Tattersall Sale Stakes at Newmarket-not a selling race, but one for three-year-olds bought as yearlings at Messrs. Tattersall's auctions. Thus he incurred a $5 \mathrm{lb}$. penalty at Epsom. I tried him to be an out and out stayer, so helped myself to $£ 3300$ to $£ 100$ against him, and $£ 800$ to $£_{100}$, in another hand-a doubtful one-for a place.

Allsopp $\dagger$ was up. As soon as the big field was round Tattenham, and in the straight, my green jacket was seen to be well in front, but not on the rails: Armada's victory seemed assured, as he had two lengths to the good at the distance, where to my horror, he was allowed to slacken off! No doubt his jockey thought he was winning in a canter, and did not want to make an exhibition of him. Fatal error! All of a sudden Dick Chaloner, on the Duke of Beaufort's Parlington, dropped from the clouds and slipped up on the rails. Before Allsopp could get Armada going again, the other had beaten him a head! Cruel luck this ! And I did not even get my place money, for my "commission agents" had come to the conclusion that it was time they "did a guy." They certainly did me!

Only once in my life have I ridden a dead heat, and it was Weasel who presented me with the record.

* Armada br. c. by Fernandez (brother to Isonomy)-Sota di Roma by Pero Gomez.

† Allsopp was only a lad at that time. 
This was at Sandown, where a good field turned out for a two-mile spin. In the straight I had everything beat but a gee ridden by " Chris "Waller. I had lain at this one's quarters most of the way, but when I went in earnest to put " paid" to his account, I found I had bitten off more than I could chew, for, try as I would, I could not peg him back. From below the distance we ran locked together, and when the winning post was reached I thought I was beaten a head. Evidently "Chris" thought differently, for as we pulled up, he exclaimed, "Well, old Cockie, you just pipped me!" But when we consulted the board we became aware that the "double $\mathrm{O}$ " had signalized that it was a case of " fifty fifty!"

Weasel's opponent was owned by William Stevens, the trainer, who readily agreed to a division.

Then Weasel had another nice little sequence of wins, before being unplaced, for the first and only time, during the period in which I owned and rode him. A rather important race, with a handsome trophy, was provided by the Sandown Executive. This was for horses that had run in steeplechases, hurdle races, or hunters' flat races, the penalties and allowances being on an extensive scale. Those that had not won a race - selling races excepted-receiving a very liberal allowance. A big and "classy" entry was secured, and a good field turned out.

Weasel claimed all the allowances, and as the going was decidedly deep, James Prince-John had died long 
ere this-suggested that, for once in a way, I should alter my tactics and come right through from the start. The top weight - the National winner, Cloister, if I remember rightly - had to shoulder 2 stone 7 lbs., and as Weasel had only ro stone $\eta \mathrm{lbs}$, a weight I could just do comfortably, the advice seemed sound enough. But class told its inevitable tale. I could never go the pace. It was a cracker! One of the fastest races I ever took part in. I had not a look in; but the unexpected cropped up. A rank outsider, yclept Mongrel, appeared to have the race at his mercy half-way up the straight, but his jockey completely lost control, and the horse zigzagged all over the course, so that one of the "cracks" was able to catch and beat him.

Now the rider of Mongrel was that best of sportsmen and good fellows, "Geoie" Gunnis. I believe this was the first time he had ever sported silk, and it certainly was the last. He was called upon by the Stewards to explain the handling of his mount. Of course, the explanation was obvious to one and allwant of experience and nervousness. "Geoie" would have given his ears to win. The idea of his trying to avoid doing so was preposterous. Needless to say, he was honourably acquitted. Lord Dudley bought Mongrel for a tidy sum, but, strange to relate, he was never again so near to winning a race as on the occasion described.

I hardly ever rode Weasel but what some interesting, if not remarkable, incident occurred, either before, 
during, or after the race. The following is a case in point :

O wad some pow'r the giftie gie us

Tae see oorsels as ithers see us!

Burns ("Rabbie" not " Tommy ").

It is sometimes very embarrassing to be an unintentional eavesdropper where one's personality and character are being discussed by others who are unconscious of our presence in the flesh; but there are occasions when such amenities are prone to fill one with much inward hilarity.

It had been my lot to encounter such an experience on two separate occasions. On one, my domestic character was being canvassed, and on the other, my ability as a gentleman rider. I will deal with the latter, the former being far too controversial, and involving issues which rest on the exact point of view from which those who have started the argument regard moral and social conventions.

The dialogue took place in a railway compartment when I was en route for the old Croydon racecourse, where, if I remember rightly, the last of the timehonoured gatherings on that sporty but sticky course was to be held.

Our compartment was full up. Opposite me were two youths, equipped cap- $a-p i e$ for the business toward. They had the impress of " the Varsity," and " not long down" at that ; but they were evidently keen on the game, and anxious to select from their cards such 
animals as would be likely to increase their respective bank balances, supposing such a pleasant possession to exist.

The said dialogue was conducted in words to the following effect :

No. 1. "What'll win this hunters' flat race?"

No. 2. "Depends on what runs. It would be a good thing for Weasel with a good man up."

No. I. "Who rides?"

No. 2. "Oh, the owner, I suppose. $\mathrm{He}$ is a rotten jockey and can't ride for nuts."

Here another occupant of the carriage-one well acquainted with my personality-tipped me a knowing wink and butted in. I will call him No. 3 .

No. 3. "Excuse me, sir, but is it not a fact that Weasel's owner has ridden him in all his races since the horse became his property and has now scored seven wins in succession?"

No. 2. "Oh, very likely, but that's because the horse is a flyer and had a stone in hand every time. 'Cockie' always looks more like falling off than winning. $\mathrm{He}$ is the hossiest man on foot and the footiest man on a horse I ever struck."

No. 3. "I suppose you know him personally?" (With another wink at me.)

No. 2. "Know him? I should just think I did! $\mathrm{He}$ is not a bad sort and we are the best of pals, but that does not alter my opinion about his riding. Now, if he would put Teddy Wilson up, I would have my 
maximum (I wonder what the figure was) on Weasel to-day. If Cockie rides I shall give the race a miss in baulk."

No. I (to No. 3). "Well, from what you say, sir, it seems that Captain Harding Cox has not done so badly after all. I shall have a fiver on Weasel and chance the ducks!"

And then the train pulled up and we each and all wended our way through "Robbery Road" to Croydon race meeting G.H.Q.

The hunters' flat race, in which Weasel and I were to try conclusions, had closed over night with a numerous and quite representative entry, and all the leading riders were at hand. The event was first on the card, but on examining it I found that-whereas all the others had claimed the full selling allowanceI had carelessly neglected to do so, and that consequently Weasel would have to allow $7 \mathrm{lbs}$. all round. Now it had been pouring in torrents all night. Those who remember the old Croydon track will realize what that meant to the going; especially on the far side of the course. The soil there was of stiff clay and about as sticky and holding as it is possible to imagine.

Whilst by no means underrating dear old Weasel's powers, I began to doubt the possibility of his being able to concede as much as $7 \mathrm{lbs}$. to three or four others of the field under such conditions. This applied especially to a gelding called Burton, which had a good record, and was the mount of one of our very best 
semi-professional amateurs. I had reckoned this gee to be about the same animal as my old joker at level weights. Nevertheless Weasel was installed favourite at I I-8 against, with Burton 2-I, and others backed from $5^{-1}$ to " any price."

I was watching mine being saddled, when enter the two young fellow-me-lads of the train journey. They began looking over the sober Weasel and then turned their attention to myself. At first they failed to identify me in my colours ; but presently "No. I " nudged his pal in the ribs and tried to drag him away. The opportunity was too good to be missed. I waltzed up to "No. 2 " and slapped him heartily on the back. "Hallo, Sonnie," I exclaimed. "Why, I haven't seen you for an age. How goes it? Going to support me and this old skin ?"

"No. 2 " grew scarlet and looked like suffering incipient paralysis. He was struck dumb.

I continued: "You had better have a bit on. If he can spare $7 \mathrm{lbs}$. to the rest of the field in this going he ought to win ; that is to say, provided I do not fall off ! Bye-bye, and wish me luck." The last as I was swinging into the saddle, leaving the lads rooted to the spot in a thoroughly disgruntled state of mind.

The start was at the end of the straight, then past the stands, once round, and in. The going on the stand side was not so bad, but as soon as we were in the back stretch we were floundering in a perfect quagmire. I had as usual taken the lead and then had 
pulled Weasel back, lying at the girths of an animal ridden by Roddy Owen, and backed only for that reason. Two "light weights," one of which was in the hands of Guy Fenwick-I forget about the otherwhich must have been veritable mud larks, were going for all they were worth, and soon opened up a gap of at least fifty yards between themselves and Burton who, in turn, was some five lengths ahead of the next batch, which included Roddy and myself. We had been having a friendly chat and paying but scant attention to the leaders, but now it suddenly dawned upon my companion, that instead of their coming back to us, we were dropping further astern, and we were now close on the final bend.

"I say, Cockie," shouted Owen, "if you want to win this race you had better get a move on. Mine is as dead as a door nail."

As long as Weasel was up to his hocks in clay he refused to accelerate his pace; but happily we struck a sounder patch on the bend. By the time we were round it we had caught and passed Burton; but there were the two outsiders playing mutual cut throat nearly 100 yards ahead, and only $4 \frac{1}{2}$ furlongs to go ! I now became aware of a little figure in a frock coat, tall hat, white shirt, and black bow tie, which looked like the impersonation of a methodist parson or a Pussyfoot protagonist. It was dancing and gesticulating wildly.

"Go on! Go on, Guv'nor-for the love of 
Gawd! I've got me bloomin' shirt on yer, and if yer don't click, I'll drown meself."

A wag (I think it was my old friend "Rapier " of the Illustrated Sporting and Dramatic Nerws) when asked how it was that a rider with such unorthodox methods as myself managed to win so many races on "impossible" animals, replied, "Oh, don't you know? I'll tell you! He climbs up his horses' necks and shouts bad language into their ears. This so shocks them that in their endeavours to avoid contamination, they exert the last ounce of effort." There is some truth in the gibe, for I had adopted a modified "monkey crouch" long before Tod Sloan, or even Simms, had proved its efficacy; whilst as for using bad language, I admit the soft impeachment; for I found it highly efficacious in the case of Weasel, at any rate. On this occasion I applied to him a whole gamut of opprobrious epithets, plus a severe one, two, three with the catgut and a dose of steel tonic. It was seldom my habit, and never my pleasure, to use whip or spur to Weasel ; but amiable beast that he was, he did not resent it when I considered it necessary, and he never bore malice; but he knew more about the alluvial peculiarities of the Croydon track than his rider, and had no intention of exhausting his vital resources until the psychological moment arrived. No sooner was he on the sound turf and his head set straight for home, than a wonderful change came o'er the spirit of his endeavours. He caught sight of the 
two unfortunates (now completely spun out, but still being urged to extremities, neck and neck, by their riders) and went for them " hell for leather !"

He simply devoured space, and came up, well you can't say " hand over fist " when describing a horse's gallop, but that describes it, and swooping down on the luckless pair, just within the distance, he sailed home an easy winner by two and a half lengths.

Next morning this feat was alluded to by the sporting press in big headlines as "A sensational race." "Weasel performs a miracle." "Never say die Cockie," etc. It seems that at one time during the running as much as 20-I was freely laid (and in some hands taken) against Weasel's chance.

The moral is that a race is never lost until another horse has won it, and even then, a reasonably lodged objection may haply result in a modified victory.

After I had weighed in and changed I was inspecting various "lepping" gees in the paddock, when suddenly my hand was seized and wrung rather painfully. It was my little friend of the bend, with the sombre, but highly respectable get-up.

"Gawd bless yer, Guv'nor!" he exclaimed fervently. "Streuth, I thought it impossible you could ketch 'em. Suppose you was coddin'? But yer put the fear of 'ell in me, gospel you did ! Thank Gawd I 'ad a tidy win too, five goldin' jerry o' goblins, an' make no bloomin' error !"

Now this little figure of fun rather interested me. 


\section{CHASING AND RACING}

I told him how gratified I was, in that I had been the humble means of replenishing his exchequer. Furthermore, I ventured to inquire what his trade or occupation might happen to be when he was not engaged in pursuing the sport o' kings?

"Well, Guv'nor," he answered, " by rights I'm an undertaker's mute, but I do a bit o' teaching in the Sunday schools most weeks."

Well! Well! Well!

Later on I struck "Nos. I and 2."

"Hullo lads!" I exclaimed cheerily on meeting them. "I hope you packed up a parcel on old Weasel. You see I did not fall off after all. I don't mind telling you, in confidence of course, that my mount ran clean away with me; but I managed to cling on by clutching his mane. Lucky, wasn't it ?"

"No. I" was silent.

"Don't rub it in, sir!" murmured "No. 2 " miserably. 


\section{CHAPTER XII}

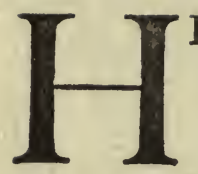

ERE is another little story anent the amiable and admirable Weasel (in conjunction with another of my " gees ") which forms, I trust, a not uninteresting item in my string of personal narratives.

The scene is laid in the billiard-room of "The Crown" (I think that is the name of the leading hostelry) at Derby. Ben Cooper and Alf Savill are trying conclusions at a friendly " hundred up." Enter your Uncle Cockie, who proceeds to watch the entertainment. On its conclusion Ben addresses me :

"Going to have a ride to-morrow, Capting ?"

"Why yes, I have a gee of sorts in The Boden Eccentric."

"Rum sort of race ain't it ?"

"Yes, it is for horses regularly ridden to hounds during the season. There will be a pretty big field, too, from all I hear."

"Have you found the pea?" this from Savill.

" Not I. I expect you knights of the pencil will set your market according to the riders, eh?"

"In which case, sir, you are sure to be favourite?" ${ }_{4} 6$ 
"Now don't be sarcastic! If you will lay me I 00-8 my chance, you can book it."

"What's yours, Capting?" interpolates the worthy Ben.

"His name is Latimer, and he is a five-year-old chestnut gelding by Touchet-Our Mary. He was given to me by Lord Chesham, and he is named after that sporting and genial nobleman's estate at Chenies, Bucks. A farmer friend has been riding him to my hounds all the season, and declares that he cannot gallop faster than you can kick your hat. I tried him with two of my smart galloways, and he was up sides with them. So now you know as much about him as I do myself. All the Corinthians from the "shires' are on the job, so there is sure to be lots of fun."

"Is that the only mount you have, Capting?" asks Ben.

"No; I shall put old Weasel in an overnight seller, for the last day, and if all goes well I shall have a jog around on him. What about that 100-8 Latimer?"

\section{"Nuthin' doin"."}

Then Alf Savill butts in.

"Look here. I'll tell you what I'll do with you, Captain. I'll lay you 2O-I against your winning both races, just for a bit o' sport."

"Not fair odds, Savill. Why Latimer will be among the "20-I others 'in the Boden."

"Well, you can take it or leave it, sir. Anyway, 
Weasel is sure to be favourite, and will probably start odds on."

Your Uncle Cockie fell to it !

"All right. You can lay me $£ 200$ to $£$ ro or $£ 400$ to $£_{20}$ if you like !"

"Thanks, $£ 200$ to $£ I 0$ is as much as I can do with, and I expect you have me boiled at that."

Now as a matter of fact, I really knew very little of Latimer, and had never been on his back; but he was a very likely looking customer, of the wiry type, and as sound as a bell. I had no idea as to the quality of the opposition; but presumed that some of our leading gentlemen jocks, who had been hunting in " the shires" would have been busy digging out some pretty useful stuff with a view to this particular race.

From what I could see of them in the paddock, before the race, some of them looked good enough for anything; they were the cream of the hunting field, and bloodlike enough for the race track.

The distance of "The Boden "was one and a half miles, starting a furlong below the distance post, looping the loop, and running in. There was some confusion when the white flag was hoisted. These "fox catchers" seemed disgruntled at the unwonted surroundings and circumstances, Latimer being one of the worst offenders. But I got him off with the leading lot, only to pull him back so as to take careful stock of the sort of cattle he had to deal with. He 
was, however, giving me a good feel and striding out freely.

I soon tumbled to it that he had the foot of the field; so I let him " gang his gait." One by one he passed the others until he lay third, and then second. As we rounded the bend for home he went smoothly to the front and took the rails. It was then that I heard a dismal wail from somewhere in the rear: " $\mathrm{Hi}$, Cockie, hold hard, hold hard a bit, don't show us up !"

Well, I took no pains to cause a lengthy hiatus between Latimer and his proxime accessit, but allowed the former to doddle on, to win by four lengths. So there was a plumb centre, with the first barrel of my double!

When I got back to the dressing-room there was a howling chorus of derision. "How do you manage to keep that tit behind hounds, Cockie?" "Have you entered him for the Gold Cup at Ascot ?" "I've got a two-year-old I think is a smasher; will you lend me Latimer to try him out? If my youngster can peg him back at a couple of stone I'm going to win the Derby "-and so on and so forth.

Certainly the gelding had pleasantly surprised me, and I came to the conclusion that he really might be able to win a "Corinthian Welter," or a long-distance "Seller" ; so I had him relieved of his fox-catching exercise and put into regular training. Presently I entered him for the principal club race at Lewes, and looked forward to a renewal of my experience as his 
pilot ; but fate, in the form of a bad attack of " 'flu," upset my calculations, though I determined to let Latimer take his chance just to see how he would shape among real, live racehorses. I obtained the services of my good friend Schwabe, who failed to land him a winner in a big field, by a neck only to the bad of Barmecide, who was then at his best. Subsequently I rode the chestnut "hunter" at Sandown; but apparently he was off colour, for he was dull and listless and gave no sort of show. Once more, for some reason or other, I had to give my ride a miss in baulk at Lewes, where he showed his partiality for this particular course by winning cleverly in the hands of my old friend and Harrow school-fellow, Major "Bobby" Fisher.

Then I put him to hurdling, and he took to the game as a duck to water. I tried him to be a veritable smasher, and got Roddy Owen to ride him over the sticks in an important race at Kempton. He came to the last flight pulling over the leading horse, and his victory seemed assured; but the other struck a hurdle and set it on end, with the result that poor Latimer hit it a resounding bang and came to his knees. He pulled up on three legs. It was obvious that he was badly injured on the near knee-cap ; and so it proved, for though put in slings, the joint oil ran, and a friendly bullet had to be requisitioned to put an end to his sufferings.

Very bad luck this! That he would have proved himself a champion hurdler I have not the least doubt 
Even a "Grand National" might eventually have crowned his career had it not been prematurely cut short as chronicled.

And now to return to my "sportive double." I must tell you that, after closing with Savill's offer, I took a more advantageous wager from a personal friend, viz. $£ 500$ to $£ 20$. So now I was on velvet; for no matter what the entries 'for Weasel's hunter's flat race might be, that amiable and reliable bit of stuff was sure to start at a short price, whereby good hedging would be as easy as falling off a log.

As it happened, the race was very poorly supported and only three numbers were hoisted on the board; but they were a notable trio; Weasel, on account of his long series of wins in similar events; Excavator, because he was the mount of the redoubtable " $\mathrm{Mr}$. Abingdon"; and Percival, because no less accomplished an amateur than Arthur Coventry was in the saddle. The betting was very close. I am not certain of the exact figures, but there were only a few points difference between the three. The result proved the accuracy of "the talent's" calculationsas presently you shall see.

Going to the post, George Baird (Abingdon) cast admiring and perhaps envious eyes on old Weasel, who was loping along like a park hack.

"What a dear old horse that is, Cockie," he exclaimed. "Why, I believe that if you fell off he would stop and pick you up." 
I smiled and assented.

"Are you going to make the running ?" he asked.

"That depends" (cryptically).

"Well, I shan't and I'm sure Arthur won't; so what about it ?"

"What, indeed?"

Well, at any rate I knew what to expect. You never saw such a barney! All three of us, when the flag fell, began as near a walking race as no matter. One would think the stakes were to go, as in some donkey and bicycle races, to the one which could contrive to come in last ! Weasel, as was his custom, at the start, was making a great show of pulling; so much so that willy nilly I was forced into the lead; but I set a pace that would have suited a sprinting snail or a tricky tortoise. Of course I was wise as to what were the tactics of my rivals. They were both riding slow stayers, hoping that I would attempt to cut them down for speed, and that they would run me out of it at the finish.

Not for your Uncle Cockie! Not on your life !

Well, we kept up this crawl until nearing the bend for home. Then, considering that the psychological moment had arrived, I suddenly caught up old Weasel (who was beginning to indulge in a nap) and shouted an opprobrious epithet in his ear, always a sure method of awakening him to his responsibilities. Immediately, he caught hold of his bit and went hell for 
leather. Before the astonished "back-markers" could take in the situation I had a good five lengths lead on the rails. Then they came after me for all they were worth. At the distance we were all level, and I had to ask my old pal to pull out a bit extra. This the gallant little chap did with a will. Then we ran in, fairly locked. I do not think any one but the judge could say with truth and precision which had won, or if it was a dead heat between the three. But I rather fancied that Weasel had it! My supposition proved correct ; so the second barrel was quite effective and the sportive double clicked. Good egg!

It is not often that IOO-I is laid in a field of three; and still more remarkable is it when the forlorn chance puts his backers (if any) on such particularly luxurious velvet. In fact I can remember only two instances. One when Jolly Sir John won a race at Gatwick at those forlorn odds, when setting back two well-backed opponents ; and the other, in which I took a prominent, but by no means heroic, part. This was at Lewes (always an unlucky course for me). There were three runners in a one and a half mile club welter. I forget the name of one of the trio-ridden by George Lambton. I was steering Trelaske; whilst the third side of this triangular "duel" was a ragged, unkempt-looking little devil belonging to that genial and optimistic old "sport," Colonel Cumberlege, Joe Miller by name, and ridden by Captain Morris. To use a well-worn aphorism, "Joe" looked as if he had 
been dragged backwards, by the tail, through a duck pond.

There was close betting as between Lambton's mount and my own; whilst IOO-I was actually laid against the gallant Colonel's "rag" of a gee. If no one else backed it, the owner did, and so the S.P. was duly and accurately returned.

" Joe " went away with the lead. Neither Lambton nor myself took the slightest notice of him, but watched one another with lynx-like vigilance. And so we ran to the straight, with the "unconsidered trifle" still holding a four lengths' advantage. The going was very sticky, and we were giving away a lot of weight, but it was not until we were about three furlongs from home that it suddenly dawned upon us that the "scarecrow" was not coming back to us, as we had so confidently expected. On the contrary, he looked like going further away. " Here, I say," shouted George of the Lambton ilk to me, "we shall never catch that joker if we don't hurry up !"

And faith, we never did!

The despised one passed the post with a very useful margin, much to the amusement and delight of the crowd, or to those thereof who had not backed Trelaske or G. L.'s mount ; for Colonel Cumberlege was a local sportsman who was immensely popular, and one who "trained" (save the mark!) his own modest string; but who seldom scored.

This Joe Miller afterwards proved that he was 


\section{CHASING AND RACING}

pretty useful, for not only did he, if I remember rightly, win another race or two on the flat, but became a quite accomplished performer over the sticks. There is a moral to this. In race riding, never despise the chance even of one that is generally considered the rankest of outsiders. 


\section{CHAPTER XIII}

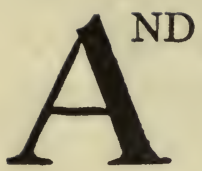

now I come to my final ride on dear old Weasel, an equine friend whom I had grown to love. A perfect understanding existed between us from the very first; and even after the lapse of so many years, I memorize the choking sensation in my throat which obsessed me when I saw him being led round the sale ring, and yet remained dumb to Mr. Steven's (the auctioneer's) stirring and persuasive appeals.

It was in the early days of Hurst Park that I had entered my old pal in the usual over-night selling event, and had instructed James Prince accordingly. When my excellent trainer met me before racing, he seemed rather perturbed.

"Mr. Johnson has entered Hugger Mugger and is bent on running. All conditions being equal it is as close as no matter between him and Weasel. What about it, sir?"

"Well, they can back the two coupled."

"Then they will have to lay long odds. The public won't have anything else, that's sure."

"Who rides Hugger Mugger?"

$$
\text { I56 }
$$


"Teddy Wilson, Captain."

(Mr. E. P. Wilson the celebrated amateur of Grand National fame.)

"Well, your other patrons are not giving anything away on the score of jockeyship are they?"

"That's just it. They think that Wilson will outride you. But there, you know how to handle old Weasel better than any one that has ever ridden him. Here's Mr. Heasman, you had better have a word with him."

Now I have previously stated that although the Johnson and Heasman confederacy followed the sport with a view to making it pay, whilst I was out for personal enjoyment, I had always been met in the most sportsmanlike manner as one training in the same establishment.

It could not be said of either that he was communicative, but a wink of the eye is often more instructive, and sometimes distinctive, than the wagging of the tongue; so that I generally had a hint-a delicate sort of hint-as to the chance of any animal that the confederacy might be running.

"Well, Mr. Heasman," I greeted him with, "looks as though our interests are likely to clash. Why not stand down with Hugger Mugger and back Weasel? Even our friend Prince here, says that there is nothing in it between them."

" Sorry, Captain, but ours is very fit just now, which is not often the case; so we must strike whilst the 
iron's hot. Why not withdraw your old fella' and support ours?"

"Not I. This may be the last race I shall ever ride on old Weasel. If he wins I shall let him go."

"Are you going to back him ?"

"Yes, for a trifle."

"Well, tell you what. Let us save a pony, or fifty if you like, that ought to meet the case."

I agreed.

"I think you will be beat this time, Captain." This from Heasman.

"Perhaps."

I must say I had a wholesome dread of Teddy Wilson's prowess, knowing how very close the respective merits of Weasel and Hugger Mugger had panned out in more than one home trial; but undismayed, I weighed out and lobbed down to the post. There were nine runners, but only the two from Lewes were backed with anything like spirit. Between Weasel and Hugger Mugger the betting was very close, the latter being a fractional favourite at I I-8 against.

In the early stages of the race nothing of interest occurred. I pursued my usual tactics. I had Weasel well placed, but made no attempt to take him to the front until well in the line for home. I was watching Wilson like a hawk, and he was returning the compliment; so as soon as I began my run he was at my girths. I am sure we both expected to come right away together, but such was not to be the case. Two 
unconsidered outsiders (one of which was, I think, ridden by Roddy Owen) joined issue, and the four of us reached the distance almost in a line, with Weasel, perhaps, a neck to the bad. He fell away by another half length; so I had to give him a sharp reminder, and call him all the insulting epithets I could lay my tongue to. Like the gallant old warrior he was, he responded with the utmost gameness. I had to come up on the far side of the course ; but having a clear run, Weasel began to peg back the others (all the riders of whom were firing off a perfect fusilade of catgut crackers) inch by inch; and as the post was reached, his head was sufficiently obvious to the judge to gain him the verdict; but the proverbial tablecloth would have covered the four of us. There was much hilarity indulged in by certain ribald fellows when I returned to weigh in, because of my unorthodox methods, and my peculiar seat, to say nothing of my habit of applying the flail to Weasel's rump instead of to his flanks, because he favoured the former proceeding, and was inclined to resent the latter. Well, the proof of the pudding was in the eating. No doubt Weasel was never so well or so carefully trained as he was at Lewes in the able hands of James Prince ; but the fact remains that during that period, I rode him eleven times; won outright, eight; deadheated, orice; was once second (I admit I ought to have won), and only once unplaced; this last when competing against others of a greatly superior class. 
Before becoming my property his average was about one win in ten starts, and often "down the course!"-verb sap!

It was a sad damper on my triumph that I had to see the dear old thing knocked down at auction for a sum amounting to over three times that which I had paid for him; but matters of a serious domestic nature * had arisen, such as demanded my undivided attention, so that I had decided to drop race riding for the time being at any rate. Weasel was subsequently sold to Lord Dudley for " a monkey," $\dagger$ with a view, I suppose, to his supplying the future Viceroy of Ireland with an armchair winning ride; but as far as I am aware, this desirable consummation never materialized.

The last I heard of the old chap was that he was enjoying otium cum dignitate, as the favourite covert hack of the Marquis of Cholmondeley.

With the inevitable straw in his mouth, his lordship told me of old Weasel's well-being and what a delightful hack he was. This I could well imagine, for his manners were perfect, and he had the temperament of an angel, despite a knocking about and "suffering it rough," such as would have converted nine blood'uns out of ten to the ways of rogues or savages.

I have more than once alluded to the fact that certain self-styled critics affected to regard me as an amateur rider of no skill or knowledge whatsoever.

* See p. 104. $\dagger £ 500$. 
Perhaps they were right. No doubt my successes in the saddle were entirely due to the merits of horses, not one of which had cost me more than $£ 200$, and most of which were acquired for about half that sum ! But I should like to remark-though without any wish to indulge in self-glorification or conceit-that never once was I beaten in a close finish; * though on one occasion when steering that most impossible and hopeless, but handsome and powerful brute, Roscidus (after being two lengths behind at the distance in a five furlong race), I just failed, by a short head, to get up and pip the favourite (ridden by Tommy Lushington) on the post. I hope I may be excused for setting forth this fact in self-vindication, but there it is. If any one wishes to contravene it, let him speak now or for ever hold his peace.

$\bar{A}$ propos Tommy Lushington, who afterwards became the trainer of King Edward's "leppers," I venture to think that he was one of the ablest and strongest amateur riders I ever struck. He was always a stumbling block to me, for I do not remember a single occasion when I had the best of him, though I had few opportunities, for he always commanded the pick of the mounts ; whereas I, for the most part, had to be content with my own humble "skins." Another of my time who invariably put " paid " to my account was Mr. W. H. ("Bill”) Moore. He was good all round, and the strongest finisher I ever remember to

* Under Jockey Club or National Hunt Rules. 
have encountered or seen. Few, if any, professionals could equal him in this respect.

By the way, I forgot to mention that, during the time I was enjoying my sequence of successes on Weasel, I was so bucked up by our mutual performances that I bethought me to look out for an understudy who would carry me in hunters' flat races, between whiles. But as previously stated, "Squire" Abingdon gave me little chance of picking up such at a reasonable figure. However, I did succeed in gathering to myself a chestnut gelding called Glenquoich, and exploited him at Windsor, where, as chronicled, Weasel and I scored our first notch. Again success was easily achieved, but this same Glenquoich was rather a rough customer, so I let him go at auction.

I now bethought me to do a little private training on my own behalf. An opportunity presented itself to me for acquiring the stables at Headbourne Worthy, near Winchester, at that time the property of Fred Hunt, senior-the roundest, rosiest little old sport in Hampshire. Fred had the reputation of being somewhat irritable and cantankerous, but he only required tactful handling and a due appreciation of his own particular views as to the fitness of speech and action concerning things in general and turf matters in particular. As a matter of fact I got on excellently with him, and enjoyed in his company some capital partridge shooting over his extensive farm. It was here that I had the interesting experience of throwing 
a leg over a Grand National hero-none other than Voluptuary, who, later on, had his activities directed to dramatic demonstrations; enacting the role of equine hero in a Drury Lane melodrama in which he was the mount of that genial artist and sportsman, Leonard Boyne, who passed away in 1920. On a previous occasion I had been on the back, for a brief moment, of a Derby winner, Hermit to wit, and had been promptly dislodged ; but "the double" is something to buck about, don't you think?

Of course Ted was installed as resident manager, being supported by his wife and daughter, Phyllis (my god-daughter), with Davis, to whom I have already alluded, as head lad. Previous to this venture, W. H. Manser, of Cadland House, Newmarket, and afterwards Martin Gurry, of Abingdon House, had had some of my gees in charge. Manser was a " character." He was an unfailing source of amusement to me, and to listen to his tales of adventure in Russia, where he was trainer to the imperial house of Romanoff, was to experience thrills of wonder and amazement. There were not wanting sarcastic oafs who were wont to say that his name should not have been "W. H. Manser," but rather R. O. Mancer. However that may be, he was a most generous and warm-hearted man, and a father devoted to his three boys, George (Woggy), Jack, and Charlie, and his dinky little daughter, Queenie; all of whom were perfect artistes in the saddle. I often rode exercise with them, and formed 
a very high opinion of Woggy's ability as a stableman and jockey. I received instruction and hints which subsequently served me in good stead. Whilst my horses were under the care of his excellent Dad he rode many of them to victory. He just missed, by half a length, winning for me "The Queen's Prize" at Kempton, on Trelaske. Strange to say the winner was the top weight, Chesterfield, who-so his owner, my friend Mr. " Cleveland" Davis, solemnly informed me after the race-had not been off the road or out of a walk for three weeks prior to the event. As the horse started at extreme odds, there are good grounds for accepting the owner's statement, apart from his reputation for unimpeachable veracity; but it was a tall order !

I have often wondered why "Woggy" Manser was not more freely patronized by owners and trainers, for he could ride round about seven stone. He never put on weight, and his contemporaries "had nothing on him" as regards style, strength, and general efficiency. Just before the Derby of r9r9, Woggy (who had been given the horses of Sir Wm. Black to train) wrote to me enthusiastically about that arch impostor, The Panther, expressing his great affection for the ungrateful animal and his complete confidence in his ability to lift the blue ribbon. Apparently he was a smasher at home; but on the racecourse! Oh, what a change was there! Perchance he had had a sharp reminder with the whip in that 
desperate struggle for " The Guineas," and, like many others of his kidney, did not appreciate the knowledge that he was "on to a good hiding to nothing," every time he set wild eyes on a kaleidoscopic display of silk, amid unfamiliar and nerve-racking circumstances and surroundings. That " a prophet has no honour in his own country" is a trite aphorism which applies to the subject of my remarks very aptly, for later on, Woggy had the distinction of being appointed trainer to the Royal stables of Spain, where he had a notable and instantaneous success. 


\section{CHAPTER XIV}

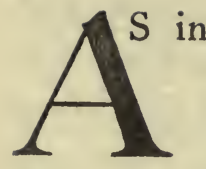

in my pony-racing days, I now began to look about me for matches which should provide me with a ride now and then as a sort of divertisement or side-show. That dear old gentleman, whom I may call the first Sir John Thursby (to distinguish him from his equally charming and genial son, whose sad and unexpected death in the autumn of 1920 was a great shock to his numberless friends), was puffed up with pardonable pride in the promise shown as a horseman by George, his younger son by a second marriage. Knowing my partiality to a sporting duel on the Turf, he approached me with the suggestion that his young hopeful and myself should have a set-to at the forthcoming Salisbury meeting, since we were each possessed of a gee whose class and form approximated-to wit, Foghorn and Trelaske respectively. So it was agreed that the match should be for $\oint_{1}$ IOO a side over the straight mile.

The event was set for decision as the last item on the card. When our numbers were hoisted, Dick Dunn, he of the stentorian voice and lurid language, bellowed out-

"Now, ladies and gentlemen, the entertainment I66 
will conclude with the popular farce, entitled 'The Unequal Match.' I'll take a pony to twenty, or any part of it. Pick which yer like ; except Trelaske!"

I do not know why the boisterous bookie should have assumed that conditions were so overwhelmingly in my favour, unless on the assumption that my then greater experience would prove the determining factor ; for on "the book" there was little between our respective mounts. However, his forecast seemed to be justified when Trelaske, jumping off in front, made all the running and reached the winning-post a length and a half in front of Foghorn.

It was not long before George was handsomely compensated by winning a nice race at Kempton on that same Foghorn, incidentally taking down the numbers of a good field of our leading jockeys.*

The hope of the House of Thursby soon proved himself an exceptionally brilliant amateur rider on the flat. Indeed, there were very few, if any, professionals who "had anything on him," as the Yanks say.

A later match between us might well have been of the "unequal" description, given mounts whose prowess was on a par, in which case the wagering on the score of jockeyship assuredly would have enabled me to take odds instead of laying them !

Having suffered defeat at my hands on the racecourse, the sportive and combative George thought to

* This, I believe, was the first race under rules won by George Thursby. 
have a cut at me at pigeon-shooting; a pastime (not a sport, mark you !) at which I had had plenty of practice, and no little success. The contest took place at Hurlingham. I think I conceded my young friend a couple of yards, which enabled him to push me very severely; but I just managed to hold my own. A return encounter produced a similar result.

My next match was not so successful. I was riding Roscidus - one of the most exasperating horses it has ever been my misfortune to steer-in a longdistance members' race at Lewes. At a mile and a half "Bill " Moore and I were out by ourselves, with the rest of the field in hopeless plight. My opponent's mount was one St. Bede (belonging to Arthur Yates), as slow as a man, but no end of a sticker, when, as now, urged by Bill's flail (and, my word, he knew how to wield it !). Roscidus, who had been running easily on a tight rein, now decided that it was not good enough to further exert himself ; so the soundly belaboured St. Bede went on to win easily if somewhat uncomfortably.

Said Moore to me in the dressing-room : "That's a useful horse of yours, Cockie; but you should keep him to shorter races. It would have been a close thing between him and my joker at a mile and a half."

"Well, let us have a match at that distance," I suggested with rash impetuosity.

Bill jumped at the offer with alacrity. 
A few weeks later found us arrayed for battle on the excellent Kempton track. I expected Bill to go hell for leather, so as to exploit St. Bede's staying powers, and to find the weak spot in my ruffian. I was not mistaken! We had hardly started when the catgut began to fall with resounding cracks on the unfortunate St. Bede's flanks. That Roscidus had the speed of him was obvious. We lay at his girths and remained there until half-way up the straight; the fusilade of flagellation being religiously kept up by Bill all the way. As " $\mathrm{Ma}$ " Yates said to me afterwards : "When I saw you sitting quiet as a mouse and Bill hard at work on ours, I thought it was "all up with us.'" Well, I had thought the same, but when I asked the beast "Roscidus" to win his race, he not only refused to pass St. Bede, but edged over, in crablike fashion, to the stand side of the course, and again Bill's mount scored.

I happened to meet George Barrett in the paddock later. "If I were you, Captain," he said, "I should take that brute Roscidus home and serve him up to your hounds. It's all he's good for. We've all had a go on him, and not one of us has ever got him first past the post, even when it seemed a hundred to one on him in running!"

A well-known and much respected dog-breaker once said to me: "When I have a real bad 'un to deal with, I take a gun to him and forget he ever existed !" This advice might have been followed with 
advantage as regards Roscidus, who, by the way, was a half-brother of the Royal Hunt Cup winner, Morionwhat a difference! I have managed to forget what the ultimate fate of this degenerate was-something with shafts and a cart-whip in it, I hope. But I cannot forget that I ever had him. He had cost me too much, both morally and financially.

I now come to a match which caused some excitement, and which afforded a fine opportunity for wags of the baser sort to indulge in airy witticisms at my expense. The fact that it was brought to an issue on the classic heath of "Head Quarters," * was in itself sufficient to draw particular attention to it, since such a thing as a private match on that sacred stretch of turf had been unknown for a generation or so. Moreover, the knights who were to be hoisted into the pigskin were of conspicuously different quality. But I am anticipating.

I happened to be travelling up from Newmarket in company with the late Mr. Deacon and another, when the striking and aristocratic looking owner named began to chip me about the ungenerous character of 'Trelaske, averring that the beast could not, or, rather, would not, win a race at any distance, even if matched with a yearling carthorse. $\dagger$

"What about your Pusher?" I asked indignantly.

* Newmarket.

$\uparrow \mathrm{Mr}$. Deacon was ignoring one or two of Trelaske's endeavours. 
"Why, Trelaske is a No. I cross between a gamecock and a thoroughbred bulldog in comparison with your quitter!"

"The Pusher is a good, honest horse, and pretty smart too," answered he of the Wellingtonian profile; "but he is unlucky."

"Unlucky be - ! Look here, I'll tell you what I'll do with you. I'll back Trelaske against The Pusher for a hundred, one mile, even weights!"

Dear old Deacon cogitated. Then, "I'll accept the challenge on one condition."

"As how?"

"That you ride your own, and that I am at liberty to put up any jockey I choose.".

Now, I had been in hopes that the Squire would ride his " thief," and that, though I should then have had to put up a matter of five stone dead weight, I might successfully cope with his equestrian endeavours.

I had intended making this my stipulation; but I was piqued by the implied contempt for my jockeyship, so, in an evil moment, I rose to the bait and was firmly hooked.

Then my sportive old friend launched another condition. Nothing would please him but that the match should be decided at Newmarket. I very much doubted if the stewards of the Jockey Club would fall in with the proposition; but eventually they did so. I suppose they possessed a strong sense of humour !

The great day came, and our show was " at the 
head of the bill ": "Match for $£ 200$, Mr. Deacon's The Pusher against Capt. Harding Cox's Trelaske, ro stone 7 lbs. each. D.M."

Of course I was curious to see whom my adversary had selected to steer his pig of a horse. I was not kept long in doubt. Who do you suppose it was? Why, none other than the redoubtable Jack Watts, then at the zenith of his fame!

So here we had a top-notch professional jockey pitted against one who had always been regarded as very small beer (despite his numerous successes) even in the amateur ranks. This promised lots of fun; but as matters turned out, the onlookers did not get much value for their money.

The track to be negotiated was the D.M. (Ditch Mile). I had Trelaske walked to the post, thinking that it would be to his advantage to be minus the Io stone $7 \mathrm{lbs}$. until the white flag was about to be raised.

Watts was already in waiting; The Pusher doing some elegant haute école gyrations.

I had drawn the rails, and Trelaske was standing quietly enough. They say that the essence of strategy and tactics is the knowledge of when and where the enemy intends to strike. Well, I knew that Watts meant outmanœuvring me. Of course he had a soft job on, and had not the slightest intention of allowing the match to be decided on the merits of the nags, pace the riders. 


\section{CHASING AND RACING}

I soon " became wise to" his intentions, when he got his mount edging away to the far side of the course. It was part of his game to lose a couple of lengths at the start. And so it turned out ; but I had no counterstroke at my command, and I never have been able to decide what I ought to have done under the circumstances. So here was I left to plough a lonely furrow on the rails, with no opponent in sight. Trelaske was doing an easy half-speed gallop, and not exerting himself in the very least. Invariably he had been allowed to run his own race. He knew-and, for the matter of that, Watts knew well enough-that any attempt on my part to apply pressure would result in a sticking in of toes, or a hurdling demonstration over the rails, by my highly nervous steed. And so we approached the distance, where the accomplished and wily Jack suddenly caught up his obstreperous mount, and before that astonished animal realized what was happening, he was forced into a short but sweet donkeysprint, which landed him past the post one and a half lengths to the good.

I had expected this, and had bethought me that, when it happened, I might perhaps counter the move by applying my whip forcibly to my boot, under the impression that such a demonstration in front of The Pusher's frontispiece would cause His Nibs to coil up there and then.

I did, in fact, take up my flail ; but what was the good, when The Pusher was fifteen yards wide on my 
whip hand? Besides, it is certain that my mount would have become quite as disgruntled as the other, and would have acted accordingly.

So ended this unique contest. The betting was $5^{-2}$ on The Pusher. There were not wanting those who sneeringly observed that the odds would have been the other way, if the riders had been reversed.

These ill-natured remarks were hardly justified, seeing that, in a mile handicap just before the match, The Pusher had been set to concede Trelaske Io lbs., though as neither of them was pulled out for the event, it is impossible to say what the respective merits of the two really amounted to. But this is not the end of this strange eventful history.

On returning to the dressing-room, where Watts was donning colours for the next race (there is no "gentleman riders" " attiring-room at Newmarket), he remarked to me in his quiet, unassuming way :

"What a brute that old Pusher is! When you took up your whip I thought it was all up with me!"

Obviously, what he meant was that the sight of my whip would cause his mount to shut up like a knife, as he had done on many previous occasions.

Of course I never for a moment imagined that the famous jockey's implication was that, in a close finish, he would have had reason to dread my prowess.

But there was at that time a so-called "sporting" paper (which had an ephemeral existence), the special commissioner of which thought fit to carpet me for 
what he termed my " colossal conceit and impudence in supposing that Watts had anything but complete contempt for my powers as an amateur (and a by no means distinguished one) when up against his brilliant professional jockeyship," or words to that effect. The paper in question was not worth powder and shot, so I let the insult pass.

But I must repeat an innocent little quip which, a propos this match, was promulgated by some joker on the prompting, I suppose, of the ever ready "Ben Trovato." It is "up agin me," but not unfunny.

The story goes that good old Jacobs, the bookie, had cherished the belief that, despite the handicap of jockeyship, Trelaske would win; so his volume was overflowing with fives to two (laid freely). He was watching the finish through his binoculars, and when he saw The Pusher and his pilot bearing down on my labouring craft, he yelled out, "Go it, Cockie! Hit him! Hit him !" A pause-and then in a subdued voice-"By gum, he's missed him!" My old friend, the late Lord Burnham, loved this yarn, and trotted it out whenever one or two were gathered together in the club lounge and I ventured to allude to my racing experiences. But the narrative was always exploited with the best of good feeling and kindness of heart. 


\section{CHAPTER XV}

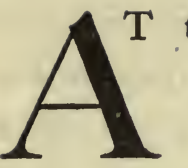

he Doncaster sales I had been greatly struck with the appearance of a slashing chestnut yearling filly bred by Mr. Russell Swanwick, and already named by him Dornroschen, by Prism-Rose Garden, by Kingcraft. Her dam, Eglantyne, by Hermit. Prism was by Speculum, but did not inherit the staying powers of the latter. In fact, he was a sprinter pure and simple; though a grand looking horse and winner of the Steward's Cup at Goodwood.

It is worthy of mention that Rose Garden was the grandam of The Tetrarch; though her daughter was the result of mating, not with Prism, but with that horse's sire, Speculum. It is possible that the suspicion of lack of stamina which attached to some of The Tetrarch's stock may have arisen on account of a weak branch on his dam's family tree. This incidentally. To my delight Dornroschen was knocked down to me for 150 guineas, and was sent to Abingdon House, Newmarket, to be trained by Martin Gurry. I saw nothing more of her until I visited the stables the following spring. Gurry had no good word for the big, lusty filly. "She's no good for racin', Squire," I 76 
he informed me. " Better 'ave 'er 'ome and 'unt 'er." I took his advice as far as change of locality was concerned, but I did not dedicate her to foxhunting.

After a while Davis, the head lad of my private establishment at Headbourne Worthy, told me that the filly could go a bit ; so I entered her in a race at Sandown, winner to be sold for $£ 600$. She was still very big and above herself; so much so, that I was chaffed unmercifully in the paddock. I gave Weldon the chance mount, and she won in gallant style, in a big field, at 22-I.

I had hardly expected such a turn up, but had " a pony each way " on her. I had to go to 750 guineas to retain her, and was thankful at that.

Now I had bought her with her engagements; but had struck her out of most of them, paying the minor forfeits. However, I left her in a few cheap races; amongst them the Portsmouth Stakes, for three-yearolds, at the Bibury Meeting (then held at Stockbridge), to be ridden by members of that select and timehonoured club.

When the day came round, it was found that Tom Cannon's ch. c. Blanc had frightened away all opposition. Had he not beaten Ravensbury by three lengths at even weights, and was not the latter always within three lengths of the mighty but lazy Isinglass? Yea, verily !

But I was undismayed. Dornroschen had by this time fined down, and had improved out of all knowledge 
in the hands of Sam Pickering, to whom I had now confided her. Besides, there was "a pony" for the second, and I was keen on a ride.

Whilst my beautiful filly was being saddled, she caught the eye of the Prince of Wales (as King Edward VII. was then).

"Has she any chance?" he asked me.

"Well, sir," I replied, " they say that Blanc represents Isinglass at even weights ; so I suppose it will be a case of $5^{-2}$ on him !"

"Why, they are laying I00-8 against yours," exclaimed the Prince. "Have you backed her ?"

"Yes, sir. I have $£ 50$ on her S.P. on the offchance."

"And I shall tell Reuben (Sassoon) to take me I000-80," and away went H.R.H. as cheerful as a cricket.

Shortly before the Bibury meeting I had gone down for a Dornroschen trial, and this came off one fine morning by the side of the Limekilns gallop.

If I remember rightly the weights were, Blankney 5 yrs., I I stone; Dornroschen 3 yrs., I I stone Io lbs., with Lord Rosslyn's Grong (I think it was) with a very light stable boy up, to ensure a true pace. Sam rode the big son of Hermit, whilst I steered "the star turn." The spin was over six furlongs only, but I had Blankney well tacked down before half the distance was covered.

Dornroschen was turned out for the Portsmouth 
Stakes in fine fettle, and gave me a splendid "feel" when cantering to the New Mile starting-post.

I had had a good look at her opponent in the paddock, and was not greatly impressed. $\mathrm{He}$ was a washy chestnut, and had a rather shifty eye, but was of good size, and showed considerable quality.

I had drawn the berth on the rails, and there I stuck from start to finish. The Stockbridge combination had a cut at us inside the distance; but as I kept my eye steadily fixed on home sweet home, I failed to catch even a momentary glimpse of the opposition, for I had a good three lengths to spare at the finish.

I am told that when Blanc's rider (that accomplished horseman, Arthur Coventry) asked him to go up to Dornroschen his " answer was in the negative !" A clear case of "I could (perhaps) if I would, but I wouldn't !"

After weighing in, and bowing (metaphorically) to showers of congratulations, I strolled on to The Lawn. Immediately cheers broke out from "The Rails."

"Come over here, Capting," shouted the usually imperturbable Fry; "we're going to have a statue in gold with diamond spurs erected in your honour."

"Did they bet?" I asked.

"Bet! I should think they did bet! Look here!" And he showed me his volume, where a 
long row of figures were emblazoned. One of $£ 5000$ to 400 , many of $£ 2000$ to I $6 \mathrm{c}$, and a whole column of fiooo to 80 on Blanc.

\section{This on Fry's book alone!}

Roughly speaking, I believe the Ring netted between $£ 30,000$ and $£ 40,000$ on this simple and otherwise unimportant spin between two starters in a $£ 300$ race!

The fact of the matter is that backers had had a lamentably sorry time on the previous day's racing, and this was to have been the "getting out" stakes. But why the knights of the pencil were so accommodating as to overlay their books, history sayeth not ; though I shrewdly suspect that they had some prescience of Dornroschen's real quality, or of Blanc's lack of courage, and having gauged the situation accurately, were quite prepared, and even anxious, to gamble, by taking 100-8 on what they had quietly figured to be a 5-2 chance!

I had been doing my S.P. business with Richard Fry's nephew, Walter of that ilk. Seeing an opportunity for pulling " the old man's" leg, I could not resist the temptation.

As "The Leviathan" was triumphantly showing me his book, I asked quietly :

"By the way, Fry, you guarantee your nephew 'W. E.' don't you ?"

"Why, certainly, Capting. How much had you on with him ?" 
" Oh, not much," I answered casually. " A matter of " a monkey' S.P., that's all."

Fry's beatific smile faded away like an Eastern sunset; but, to do him justice, he did not turn a hair, or alter the tone of his voice. All he said was, "Good luck to you, Capting. That will be all right!"

Then I undeceived him, and he heaved a gentle sigh of relief. I have much to say about Dornroschen and her remarkable achievements; but must leave the subject over for future exploitation, simply recording here and now the fact that she won the Nottingham Handicap ( $£ 1000$ ) as a three-year-old, ridden by Morny Cannon and carrying 8 stone ro lbs. In so doing she cut the time record for a mile, previously held by the bold Bendigo, when as a five-year-old he won the "Lincolnshire" with only 8 stone 5 lbs. up !

"Some" filly, this daughter of Prism, eh? For nine years she held the record, and then it was lowered by Wallace Johnson's Harrow at Lingfield.

The last of these strange eventful histories of matches materialized under the following circumstances. My friend, Sir James Duke, "owed me one." Had I not intervened between his well-backed favourite (on two occasions) and the winning post, on my trusty old Weasel ?

In a certain race, to wit, the Kempton Cup, there were three runners only; viz. Sir J. Blundell Maple's Macuncas, Mr. B. L. Cooper's Blankney, and Sly 
Shot, ridden respectively by Wingfield, Watts, and Morny Cannon. The betting was close: I I-IO Macuncas, 9-4 Sly Shot, and 100-30 Blankney. The weights were level, as all three were five-year-olds, and the distance five furlongs. The result was also a near thing between the favourite and the outsider Blankney. The latter won by half a length, and when submitted to auction he fell to my bid of $£ 200$.

Soon after this Macuncas won the Stewards' Handicap Plate at Hurst Park, and was knocked down to "Jimmy" Duke for exactly the same figure as it had cost me to become the owner of Blankney.

I was discussing with my fellow amateur the result of the previous race in which these redoubtable steeds had met, and in which Jimmy's new purchase had suffered a narrow defeat. He ventured the opinion that were they to meet again these positions would be reversed.

Here was my opportunity! I immediately butted in with the proposal of a friendly and sporting match. Sir James rose to it. He made no secret to his friends that Macuncas was a greatly improved animal, and that he was convinced that he could outmanœuvre me in jockeyship. But I had a card up my sleeve which the sportive owner of Macuncas had not taken into consideration.

This Blankney was a colossal racehorse, one of the biggest ever seen on the turf. He stood well over seventeen hands and had enormous bone-in fact, the 
very ideal of a weight carrier-which is rather odd, seeing that he was by the sensational Derby winner Hermit, who was by no means a " big 'un!"

On the other hand, Macuncas was a medium-sized and rather lightly-built customer, but a sharp mover, which Blankney was not, though he had the action of a pony, and when well under way could foot it very respectably over five furlongs; but was better at sixhis limit.

Now I figured it out that Blankney could carry weight far better than the other. In fact, I knew that he could go just as far and fast with ten stone on his back as with six; for which reason he was of no earthly use for trying two-year-olds, as he simply pulverized the smartest and most "classy" of them, no matter what weight was heaped on him.

Therefore I concluded that with Io stone $7 \mathrm{lbs}$. each, this match would be a real good thing for mine, provided I could jump him off on decent terms. I fancy that at one time or another he had been badly kicked at the post, for he often refused to join his horses and line up properly, though in other respects he was a model of decorum, with a beautiful mouth and manners -a real treat to ride!

Now this match had been arranged to take place at Lewes on the first day, and was for $£_{\mathrm{I}} \mathrm{IOO}$ a side, five furlongs. I had Blankney in a club welter at the distance named; so I had asked Jimmy if he would consent to the match being postponed to the second 
day, provided that it could be so arranged. His reply was that if I would double the stakes he was quite willing, which was in itself a startling proof of his confidence in his ability to put "paid" to my account. Of course I jumped at the offer ; so the stage was clear for the performance. I had made a pretty shrewd guess at the tactics which my rival had decided on. I knew he would try to cut me down for speed in the early stages of running, and then strive to keep his advantage before Blankney's longer stride could tell effectively.

But I did not calculate on his allowing me to take the lead at the start. However, this is what he did. He lay behind me for a couple of furlongs, and then tried to " rush" me in the dip. But it was no good. With Io stone $7 \mathrm{lbs}$. on the back of each, Blankney could go faster than his smaller and less lusty rival, so he passed the post a very clever winner by half a length (exactly the same distance as separated them when they had previously met, with professional jockeys up), never having been headed from start to finish. So much for Macuncas! 


\section{CHAPTER XVI}

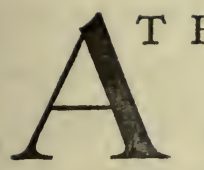

Headbourne Worthy we had a small but fairly useful string besides Dornroschen, who was only at the home establishment for a short time before I sent her on to Sam Pickering's establishment at Kennet. Trelaske was the "daddy," and he did yeoman service as a trial nag, besides picking up a few nice little races. I won the High Peak welter (for gentlemen riders) on him at Derby. On that occasion I had some doughty opponents, including Arthur Coventry and "Rock." Going to the post, the latter said, "You (with the accent on the personal pronoun) will win this," and I did, quite comfortably. The race was over the straight mile. I jumped off in front, made all the running, and won by a length.

Originally Trelaske had belonged to "Charlie" Merry, who chipped me because I had entered the son of The Miser in a two-mile race.

"Why, when I had him," he sneered, " he could. not stay five furlongs!"

"That is exactly the reason why I have put him to long distance work," was my cryptic reply, which may have sounded rather paradoxical ; but the fact is I 85 
that some horses are gifted with a turn of speed which they cannot keep up for more than, say, four furlongs, when fully extended. Consequently they are failures as sprinters, but may blossom into useful customers over long distances, because they are not put to extreme pressure in the early phases of a race, and so have a reserve of speed to finish with. That is why one of the best methods of obtaining smart performers over the sticks is to watch carefully the five-furlong selling races during the "legitimate" season, and if you see a youngster out by itself at three and a half or four furlongs, but nowhere at the finish, put in a claim and lay your purchase by until the following season, when, if judiciously trained and schooled, it is almost certain to win a hurdle race-of sorts.

I once ran Trelaske in an all-aged long-distance handicap (selling race) decided at Newmarket over the Cæsarewitch course. He ran well, but found one of the younger generation too good for him. I have already chronicled how I won the match with him against George Thursby's Foghorn, and also how he was just beaten for 'The Queen's Prize at Kempton.

Before my horses were dispersed he was sold privately to Wm. Stevens, the trainer, for "a monkey," but his new owner had no luck with him.

Trelaske was a kind and amiable creature, but rather nervous. He hated the very sight of the whip. To attempt to get a bit extra out of him by the use of that cruel and superfluous instrument of torture was 
to court disaster. He had had some! A curious incident once happened when I was riding him at Lewes. It goes to show what extraordinarily retentive memories horses have. $\mathrm{He}$ was entered in a mile and a half race which started on the remote side of the course. I was the first to leave the paddock. By way of giving my mount a pipe opener I bowled him sharply along the straight. All of a sudden he pulled up dead, and stuck his toes in. Nothing I could do in the way of coaxing or objurgations could induce him to budge an inch. I now recognized that we were at the five furlong starting-post, from which he had not raced since his two-year-old days; but he evidently knew and recognized it as the correct mark for his business. By-and-by the rest of the field came cantering past us, whereupon this rival of "Mr. Datas" consented to join the gay throng. Incidentally it was at this meeting, if my memory does not play me false, that I had the unpleasant and saddening experience of seeing a man killed by lightning. Just as I was dressing, after a race in which I had taken part, a terrific thunder-storm broke over the stands. A blinding flash of lightning was instantaneously followed by a deafening crash. A great commotion at the entrance followed. I ran out and saw that a drag with a pair of big bays belonging to Mr. Steanning Beard was almost out of hand. As the coachman was trying to master them, another vivid streak descended. $\mathrm{He}$ fell off the box and lay still, whilst luckily a plucky 
bobby had got to the head of the terrified horses. When we picked the unfortunate Jehu up he was stone dead. At the back of his neck there was a charred hole as if a red-hot poker had been thrust into it. His nether garments were tattered and scorched, the cushion of the driver's seat was ripped open, and the course of the electric fluid could be traced by the destruction of one of the spokes of the off fore wheel, the iron tyre of which was torn from its holding. What a titanic force is this which we dare to chain to our uses!

To hark back to the marvellous memory possessed by the equine race. It will be remembered that I had a word to say about a favourite hunter of mineMelbury, to wit-whom I hunted with my $M$. and H. V. Harriers when residing at Missenden Abbey. Three years later, when master of the O.B.H., I had by chance to pass that ancient landmark, having whipped off some six miles distant. I was walking the hounds quietly back to kennel, when, on reaching the Abbey, Melbury suddenly turned in at the gates and trotted up the drive. Out of curiosity I allowed him to " gang his gait." Sure enough he never stopped until he was in the stable yard. He had never been to Missenden between times.

A useful and handsome, but very unlucky, horse that we had at Headbourne Worthy was Chevy Chase, a chestnut by Ossian (winner of the St. Leger of I883)-I Spy. I won only one race, a mile and a 
half welter at Croydon, with him, but he was second to the Cæsarewitch winner Speed in the $f_{1} 000$ Rose Handicap at Newmarket.

There was an occasion when he ought to have scored at Hurst Park. "Squire" Abingdon was riding the favourite, which ran out six furlongs from home. I was then left with the lead, but instead of making the best of my way home, I began to take matters easy, to such an extent that George managed to bring his mount back to the straight, where he rode him to such good purpose that he was able to pounce upon us at the distance and put " paid " to the whole bunch.

Later, I was riding "Chevy" in one of the Bibury "Corinthians," when he suddenly stumbled and stopped as if shot. Both bag sinews had gone. Of course I dismounted, but it was with great difficulty that the poor creature hobbled back to the paddock. Davis did not consider his case hopeless, and so skilfully was the horse treated that the following season he came out comparatively sound. $\mathrm{He}$ ran in the Ascot Stakes and led into the straight, where the old trouble found him out and he broke down beyond repair.

Another of my cheap purchases (under "Lord Exeter's Conditions") was a colt called Andante, who won the valuable Orleans Nursery at Sandown, and other nice races. As a three-year-old he was seldom in a race with a weight that would permit of my riding 
him. I had one go at Lewes and finished third in a big field. I had great hopes of him in later days; but he contracted a fatal stable vice, which sapped his strength and substance.

A little fellow worthy of note was one "Penny Plain," by Discount-St. Valentine (note the nomenclature; I won a two-guinea prize for it). This was the first winning racehorse I ever bred. He first saw the light at my Chorleywood Stud farm. His sire, Discount, who won the 1880 Portland Plate at Doncaster, was given to me by Lord Chesham; but at the time, I had only a few galloway and hunter mares to put to him. One of the former was the dam of Penny Plain. As she was incapable of winning even a selling hurdle (pony) race, it says much for Discount's prowess as a sire, or the excellence of the Chorleywood pasturage, that she should produce a colt capable of winning a couple of superior selling races at big meetings. $\mathrm{He}$ was only a midget, very little over fifteen hands, but as pretty as a picture. When a two-year-old I gave him to "cousin Ted," in whose colours he ran and won. This emboldened his owner to invest in a useful plater of the name of Stanton, with which he annexed "The City Bowl" at Salisbury.

I have already explained how-because I had a limited income and no capital-I was unable to buy expensive yearlings on the "p'raps" principle. I had to content myself with picking up undersized youngsters at the sales; or " platers" at racecourse 
auctions that I considered might be capable of development and improvement One time and another I had some funny old crocks to deal with, together with a wonderful collection of youngsters which no one else would bid for. But having regard to the material which I was able to command, I think I am entitled to consider myself to have been uncommonly lucky as regards my selections.

I have had an eye for a horse, hound, or dog from my earliest days, and was always well furnished with that critical faculty which enables the expert to tot up the points of symmetry and balance in any domestic animal which he has under observation. Perhaps it was this gift, plus a kind of intuition, which enabled me to pick up, for a mere song, animals which bore my verdant livery with some sort of distinction. The following schedule is surely a revelation of cheap winners of sorts :-

* I. ARMADA, br. c. by Fermandez-Sota di Roma by Price paid.
$£ \quad$ s.

Pero Gomez .. $\quad$.. $\quad$.. $\quad$. $\quad$..

(Winner of the Tattersall Sale Stakes, Newmarket. Beaten a short head (through carelessness of his jockey), in the Great Metropolitan, etc.)

2. WEASEL, br. g.

(Winner of 8 firsts, 1 dead heat, $I$ second, $x$ unplaced.)

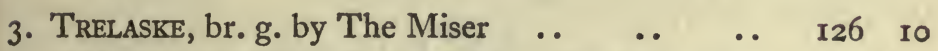
(Winner of High Peake Welter (Derby), £100 match ; 2nd in Queen's Prize, Kempton, etc.)

* Purchased at auction as yearling. 
* 4. Dornroschen, ch. f. by Prism-Rose Window ..

(Winner Nottingham Autumn Handicap, frooo, 1500 setting up a mile time record which she held for seven years; won Portsmouth Stakes, Bibury ; 2nd Hurst Park Cup, beaten half length, giving Victor Wild 9 lbs., etc.)

5. Blankney, b. h. by Hermit-Assegai

$200 \quad 0$

(Won Bibury Welter, $£ 400$ match, etc.)

*6. Andante, br. c.

(Won the Orleans Nursery, Sandown, etc.)

* 7. Chevy Chase, ch. h. by Ossian-I Spy .. . . Ioo (Won Corinthian Welter, Croydon, and 2nd to Speed for $£_{1} 1000$ Rose long distance Handicap, Newmarket.)

* 8. Chandelier, ch. c. by Prism-Hostess .. . . 35 ○ (Won $£ 200$ selling race, Kempton.)

* 9. Guinevere, b. f. by Laureate Chanthus .. . . $20 \quad 0$ (Won twice Alexandra Palace, etc. In Belgium she won over $f_{5} 500$ in stakes.)

Io. LAtimer, ch. g. by Touchet Our Mary. (Won Boden Eccentric Stakes, Long Distance Welter, Lewes, etc.)

* ir. Belle Brummel, by Beau Brummel ... $\quad$. 25250 (Won selling race, Manchester, 24 runners.)

12. The REEFER, (winner of Chester Cup) . $\quad \begin{array}{llll}\text {. . } & 25 & \text { ○ }\end{array}$ (Won selling hurdle race, Kempton.)

13. Penny Plain, by Discount-St. Valentine. Home bred. (Won selling race, Kempton.)

14. Palmwearer, ch. $c$. (Won selling race, $£_{200,}$ Kempton.)

I5. GlenQuorch, ch. g. (Won selling hunters' flat race, Windsor.)

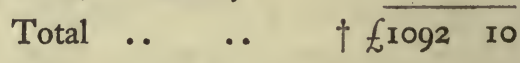

* Purchased at auction as yearlings.

$\uparrow$ These horses won over $£ 5000$ when running in my colours. 
The only cheap horses bought for less than $£ 200$ which ran for me and failed to win were, I think, that king of thieves Roscidus and a filly called Pretty Wit ; but there were one or two which I bought at auction as yearlings which could not be trained, including a very beautiful filly called Rêve Royal, by Royal Hampton-The Dream. She showed extraordinary promise and won a big trial, but subsequently split a pastern and never ran.

After Dornroschen's amazing performance in the Portsmouth Stakes, I was encouraged to invest my winnings and to launch out. Lord Rosslyn was selling his string, and Sam Pickering was very keen on my buying the ch. filly Sybil Roy, who had won a highclass two-year-old stake at Newmarket, and another important race, also a rather small bk. c. called Grong, who, Sam said, was sure to pick up a nice race. Well, Sybil Roy was knocked down to me for I 200 guineas, and Grong for 300 guineas. Neither was ever even placed after becoming my property! Sybil Roy first turned jady and then became an absolute maniac. No one could do anything with her. I sold her as a make-weight to the elder Sir John Thursby, when he took over Dornroschen, Blankney \& Co. His son George afterwards told me that the filly had been covered by the last-named, and that she had thrown a foal-I forget its sex-which turned out as madly intractable as its dam. So much for my "investment"! $\dot{A}$ propos "forgetfulness of sex," a good 
story is told of Lord Marcus Beresford, who had become a proud father on the morning of a fashionable race meeting, at which he was due to officiate as starter. He was cantering to the post past the club lawn, when he was hailed by a fair friend, who called after him-

" Hi, Markie, I hear you have become a father this morning. Is it a boy or a girl ?"

Turning his head over his shoulder, but without pulling up, Lord Marcus shouted back-

"I don't know. I forgot to look!" 


\section{CHAPTER XVII}

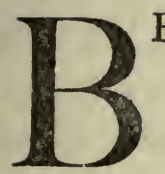

EFORE finishing with horses which I have owned and ridden, I must say a few more words about Dornroschen, as she was undoubtedly the best class animal that ever passed through my hands or took me on as an outside passenger.

When she passed into the ownership of the elder Sir John Thursby she was the victim of one of the most untoward accidents that could possibly befall. For the second year in succession, she was entered for the Hurst Park Cup, and the weight allotted was such that, if anything like in her best form, she was "the catch of the season." And so thought George of the House of Thursby. Twelve months previously, in the corresponding event, she had presented the allconquering Victor Wild with a lump of weight and had run him to a head. The handicapper had now reversed the position, and Dornroschen was set to receive a similar poundage. What could be nicer, seeing that the twain were of the same age?

The public view coincided, so that $4-\mathrm{I}$ was the best price obtainable. The filly was as fit as the proverbial fiddle, and everything pointed to a happy 
issue for all concerned. Of course I was in the swim, for George and his excellent father were ever ready to "slip me over the goods!"

But an evil "hoodoo" was lurking round the corner. Literally so, for on the field emerging from the paddock, which is situated at the back of the stands, and therefore out of view of the crowd, a mad brute called Galloping Dick, belonging to Douglas Baird, and ridden by Freddie Pratt, suddenly bolted and barged into Dornroschen, catching her fairly on the flank, and sending her and her jockey-Allsoppto the ground, where they lay with all the wind knocked out of them. It was quite three minutes before the filly was on her feet again and Allsopp in the saddle. Meanwhile George and I, who were in the stand, were wondering where on earth Dornroschen could be, for the rest of the field were already at the post. My companion was just about to start on a voyage of discovery when we viewed our hope and joy being led along the back stretch.

We could not make it out.

Had the full significance of the contretemps been known to the Ring, it is reasonable to suppose that the bonnie chestnut would have "gone out with the washing," but as it was, the price did not lengthen.

At last they were off! As the field swung round into the straight, with its rather short run in, it was seen that Dornroschen was leading on the rails and apparently going easily; but close home she was tackled 
by her famous opponent of yore, Victor Wild, who, after a short, sharp tussle, pegged her back into the proxime accessit position, for the second time of asking!

It is practically certain that this obviously good thing, on the book, would have materialized; albeit, as previously stated, I had by that time come to the conclusion that my erstwhile flyer did not really stay a mile, malgré her capture of the time record at that distance. Moreover, I feel convinced that after going seven furlongs she was subject to some spasm or stitch, which caused her to shut up like a knife, or to swerve right across the course, for I am sure she was not a wilful jade, as some have supposed. I wonder how many race horses have suffered ignominy and have been decorated with "the rogue's badge" owing to similar causes over which they have no control, and which do not, in any way, owe their origin to temperament.

On the other hand, I also wonder how many shifty customers are so created by the cruel and injudicious use of whip and spur?

A propos Dornroschen being "chucked into" a handicap, I recall that she was entered as a three-yearold in the Cambridgeshire, the same autumn that she won the Nottingham Autumn Handicap, in which, as stated, she established the mile time record. In the former race Major Egerton had treated her as if her name were "mud" or "dud," or something equally 
contemptible, for he had actually placed her at the bottom of the handicap!

Her success at Nottingham entailed a 14 lbs. penalty for the great Newmarket race, so I struck her out.

On the morning when the latter event was set down for decision, I ran across the official handicapper in the paddock. "Here, I say, Cox," he greeted me with, in his genial way, "I owe you a great debt of gratitude. How can I repay you ?"

"As how ?" I asked innocently.

"Oh, for running that filly of yours, Dornroschen, at Nottingham and picking up a penalty. Why, my dear chap, I had made you a handsome present of The Cambridgeshire, and you go and chuck it away as if it were not worth your serious consideration."

Well, that may have been so; I have felt regrets myself, and yet I have an idea that the " extra bit " up the hill would have found out the weak spot in my favourite.* On "the book" she undoubtedly was, as the gallant Major said, a stone-cold certainty!

Oh yes, taking all in all, Dornroschen was assuredly a most unlucky animal, but one of singular brilliance, when conditions favoured her.

There was a time, well within my memory, when every one believed in a "Jockey Ring," and probably not without cause, though I am inclined to think that

* Also there was the question of a suitable pilot. Dornroschen was not a " boy's mount." 
the pessimists and cynics were wont to exaggerate their figuring of the situation. On one or two occasions I myself harboured well-founded suspicions, and in one particular instance the facts were eloquent of the truth of the supposition.

The case in point which I propose to quote is gospel ; but for obvious reasons, names of all concerned, except my own, must be omitted.

I had tried a youngster which I owned, to be pretty useful in his class-he was only a little one. Let us call him "Ballroom." I entered him in a selling race at one of our leading suburban meetings. Not having secured a jockey I was making enquiries, when one of our leading artists in the saddle accosted me, asking if I had engaged any one to ride my representative. On my answering in the negative, he expressed his willingness to be the pilot. Now this was a real top sawyer among the jockeys of the day. We will name him, quite fictitiously, "Corfield."

Of course I jumped at the offer.

I had presented my S.P. merchant with a commission for "a pony" each way in the morning. In the betting Ballroom opened at $5^{-I}$, probably on account of the said commission; but an ominous opposition set in and he was driven out to 100-8, in spite of, or possibly on account of, the "reputation" (this is cryptic !) of his jockey.

There was a big field, and in the race my green jacket was conspicuous in the ruck, but was never seen 
in a very prominent position. Ballroom finished about seventh. Subsequently I asked Corfield what he thought of his mount, and whether he could not, by a little extra pressure, have gained the place for which I had backed my colt, and which I had urged the jockey to do his utmost to secure.

"He's a very nice little fellow, Captain," replied that worthy. "I could not have got a place, even if I had knocked him about, and that would have been a pity; but if I were you I would put him in the overnight seller. I will ride him again for you. $\mathrm{He}$ may do better next time."

I demurred, because I felt sure that some of those that had been well in front of Ballroom would be reentered; and so indeed it turned out. But Corfield was so insistent that I was persuaded to fall in with his views. Sure enough, when it came to the race on the morrow, the names of the gees which had finished $2 \mathrm{nd}, 3 \mathrm{rd}$, and $5^{\text {th }}$ were amongst those hoisted in the frame; so I was thoroughly surprised when Corfield took me aside and urged me to support Ballroom with my maximum -in vulgar parlance to " put my shirt on him."

"But," said I, " there are at least three in the race that were a street in front of him yesterday."

"That may be," replied the jockey, "but your little fellow ran rather green; now that his eyes are open he is sure to do better."

There was something in the argument, but " not 
sufficient to justify a plunge," as I meekly put it to Corfield.

"Well, Captain, don't say I didn't give you the office ; it is time I was up." And away he went.

I was left guessing.

I had not backed Ballroom this time S.P., so now went into the ring to see what was happening and approached Fry.

"What price mine to a pony?" I asked.

"Five to two to you, Capting. Here, $5^{-2}$ on the field, who'll have it?"

"You are off the line, Fry," I said. "I am not backing the favourite. I want a fair quotation mine."

"Which is yours, Capting?"

"Ballroom !"

"That is favourite. I'll lay you 100-40 or any part of it."

"Nothing doing !"

"Best have a bit, Capting. I'm told it's a cert ; it'll be 9-4 directly."

I took the 100-40, feeling quite bewildered.

On all sides the " nuts " and " fans " were tumbling over one another to back what seemed to me, who ought to know, to be an utterly false favourite.

By-and-by the shout was 7-4 on the field, and nothing asked for, except my inconspicuous little joker.

As soon as the flag fell I could see the green jacket well in the van, and at the distance it flashed out and 
eventually passed the post quite two lengths to the good.

"What did I tell you ?" asked Corfield, when he had weighed in.

"Oh, you told me quite a lot," I said; "but you did not tell me all. I guessed the rest !" ..."

"Here, I say, Captain, I hope you don't think

"No, Corfield, I don't think-I know!" and I turned on my heel, leaving the jockey looking unutterable things.

This coup had been cleverly engineered. I had been given the tip all right (Corfield, to do him justice, would never let an owner down if he could avoid it); but I was much annoyed that the pawn in the game had been one of my modest home-trained gees.

It was in connection with this unsatisfactory era of Turf history that a certain gentleman trainer, a great friend of mine, told me an amusing yarn.

$\mathrm{He}$ had tried a two-year-old colt to be something out of the common, and figured that he had quite a stone in hand in a certain nursery.

$\mathrm{He}$ also possessed a diminutive apprentice named, let us say, Martin Hannighan (obviously a lad from the distressful country), who had shown himself to have head and hands and an excellent seat. So on the occasion of the début of this smart colt, he decided to put Martin up and thus to reap the benefit of the apprentice allowance. 
When the midget was mounted, my friend, himself " a paddy," said to him, "Mind ye' here, Martin, uts winnin' this race ye'll be, but it's not be a length av a shtreet! Just come along home quiet and comfortable, wid just a length in front av the next to ye. Is it understandin' ye are, ye little gossoon?"

"Aw faith, Misther Terrance, uts meself as knows phwhat ter deu, and uts doin' ut oi'll be !"

But to the amazement of the trainer-owner, no sooner was the "off" signalled than Martin was seen to shoot his mount out, and coming along hell for leather, to win by a dozen lengths. He entered the paddock gates grinning from ear to ear; and here his employer, boiling with righteous wrath, met him.

"Oi've done ut, Misther Terrie," yelped the lad in high glee.

"Done ut?" gasped Terrance, "Oi shud think ye have done ut! Ye've exposed me colt, and now phwat chance will that same be having in the next handicap? Phwat did I tell yez, ye blitherin' little omadhaun? I told ye to win by a length of yez mount and not be the length av a shtreet!"

"Aw faith, I knows, Misther Terrance," murmured the now sobering child; "but ye see, whin we was loined up, uts meself as was squozed in atween Misther — and Misther — (naming the Robber Chief of the Ring, and his lieutenant, the terror of the lesser fry and apprentices, and the despair of the handicappers, but withal very capable and "fashionable" 
jockeys), so phlaze yez 'anner uts meself pwhat thought oi'd best be comin' the shortest way home, the whoilst ut wuz a divil's chance they'd be givin' me !"

On consideration my friend whole-heartedly endorsed the policy of his apprentice.

Here is another story of crookedness, but this time the alert jockey was the means of defeating the intended ramp on the part of the owner.

I happened to be in "the provinces" engaged in the "gentle art of the angle," in the vicinity of a local racecourse, where meetings were about to be held under N.H. rules. At the hotel where I was staying I ran across a certain gentleman rider whose name was, let us say, "Bob Clasper." Bob was " some" rider over sticks and between flags, believe me! He was dead keen on the game, and went "on circuit" to all the little country meetings. When he chanced on a good thing he was wont to plank down a modest stake, and by so doing, managed to pay his " expenses." Occasionally an " extra special " would induce him to have a splash.

Now I had done him a good turn once upon a time, and he was so grateful that he implored me to give the trout a rest, and to come over to the said meeting, when he would put me on to something on which, as he put it, I could "wáger my happy home." He proceeded:

" Cockie, old sport, I am riding in " The Farmers" Steeplechase," the last race on the card, and I am sure to win. My mount is a local, a sure and safe 
jumper, and has been tried to have a couple of stone and the length of Wigmore Street in hand."

"Well, Bob, you're very optimistic. Why the good thing is sure to be blown. It will be a case of laying long odds on, won't it ?"

"Oh no, my Cockie! Trust your Uncle Bob. He knows something, and will engineer it for all it's worth."

I was left guessing-as usual.

Now there were two days' racing at the pitch in question, and Bob's wonderful " cinch" was entered on each of these. When the betting opened The Ploughman, as the horse was not called, was a hot favourite, but no one would invest a penny on him. The owner was looked upon as "hot stuff," and those who were "in the know" always sat tight until they sensed that the stable money was on.

On this occasion nothing could be traced to the right source. The consequence was that the lads with the pencil began to open out, and soon " 5 -I The Ploughman" was offered. All of a sudden two quiet individuals, unknown to local talent, began snapping up the price, and again the "tiller of the soil " hardened in price. Meanwhile Bob had weighed out and was mounting, when the owner approached and addressed him in an undertone.

"Look 'ee 'ere, Muster Clarsper, just canter down until ye gits tu the end of the enclosure rails. Oi'll be standin' 'undred yards further down ter give 'ee 
yer instructions-see?" Bob signified his assent, and when he arrived at the trysting place, pulled up and leaned over to hear what his patron had to impart.

"Now, guv'nor," began the latter, "I want yer ter take pertic'ler notice of wot I tells yer. A nod's as good as a wink to a blind 'os, ain't it? Well, I don't want yer to knock the old varmint about in this race, twiggy voo? 'Es in the Farmers' Cup termorrer, an' us can get a good price. Ter tell yer the honest trooth, I 'aven't a bean on 'im for this yere journey. You kin ride 'im ter-morrer, an' stand in fer all yer wants. I needn't say no more, need I ?"

"Good gracious!" exclaimed Bob in well feigned amazement. "Do you mean to tell me you have not backed the horse for this race? Oh, that's a great pity! If you haven't backed him, $I$ have. Five fifties, old sport! And what's more, I'm going to win!" (And win he did, in a common trot.) "Gee up, hoss!" and away he cantered to the post.

For a moment the owner was struck dumb and paralytic. Then, having found voice, he gave way to the most obscene and blood-curdling invectives.

"Come back you x-y-z scoundrel! a-b-c your soul ! I'll report you to the stewards you d-k-1!"

Wafted back on the gentle breeze came the faint retort, " $X-\Upsilon-Z$ scoundrel yourself. Report away!"

The following yarn may be a chestnut, but it is probably new to some of the readers, if there are any, of these rambling reminiscences. 
An old jockey, of transcendent fame in his day, lay dying. He sent for his son, a promising apprentice attached to a "fashionable" stable.

"Robbie, my lad," he said in a feeble voice, " my number's up. I can't keep out of the way of the black horse. He's at my girths-I'm beat to blazes ; but before I weigh in I want to give you a word of advice. It is, never speak to another jockey in a race! I did once, and once only, and have regretted it ever since. It was this way, sonnie. Me and Jimmy Bowster was out by ourselves in a mile and a half race at Ally Pally ; rest of the field strung out and off the map. As we comes round the bend for home the last time I shouts, 'Go on, Jimmy, I ain't a spinnin!' 'The 'ell you ain't !' he sings out. 'No more ain't $I$,' and off he falls, leavin' me to come 'ome all on me lonesome!" 


\section{CHAPTER XVIII}

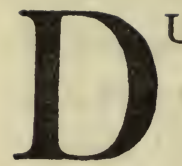

URING the "eighties" of last century there appeared on the "Turf" a young sportsman who attracted a great deal of attention. He was known as "The Jubilee Plunger," though his correct patronymic was Ernest Benzon.

In the genesis of his career he was possessed of very great wealth, the unrestricted handling of which devolved upon him when he attained his majority, which happened to be in the year when the somewhat austere Queen Victoria celebrated the jubilee of her protracted reign; hence the first word of the term bestowed on young Benzon.

It is hardly to be wondered at that his exchequer attracted the wolves and hyenas of the Turf and their jackal parasites. Poor Ernest soon proved himself to be a striking example of that paradoxical production the "fly flat." He rated his own intellect very highly, but was no match for the many devices of crookdom, which were directed at his purse strings, despite the fact that he had enlisted the personal patronage of no less an expert in turf and other matters than Sir George Chetwynd, who undertook the office of guide, 208 
philosopher, and friend to the youngster. The sporting baronet did his best to shield his protégé from the clutches of the harpies, but Benzon was of a headstrong and wilful disposition. He executed his own commissions and made direct attacks on the ring in propria persona.

It was not long before I became acquainted with this tall, slim, and dark young fellow, whom I found to be cheery, warm-hearted, and sympathetic ; moreover, we shared the mutual love of animals and little children.

In his latter days of adversity, when living in Jersey, this excellent trait stood him in good stead, for he was never so happy as when wandering on the seagirt confines of that island with a troop of ragged children and mongrel dogs at his heels. Before this he had resorted to the most desperate plunges, generally in some selling or other unimportant event, whereby he was, of course, asking for trouble - and he got it ! I fancy he was freely fleeced at cards; but one of his favourite methods of burning cash, and daylight, was to challenge at pyramids those who were obviously a class above him, as regards that excellent fighting game; with the result that, in some cases, he had the pleasure of winning two or three games running, only to lose all the financial gains he had so acquired, owing to the fact that his opponent had made certain of winning the next two, when the "Plunger" had quadrupled the stakes on himself! 
I was told that Benzon was a pretty good player; so one evening after dinner I took him home and gave him a try out on the domestic cloth of green. He began by conceding me two balls off the table. That proved too much of a handicap. In the end we were a fair match when he owed me two, at which I won four games out of seven. We were playing for money too ! One penny a ball! On this showing I figured that he had overrated his skill, for I do not count myself much more than " useful" at the game.

There came a time when this really nice young fellow side-slipped; though I am sure the "crime" was committed owing to thoughtless innocence rather than through deliberate turpitude.

After he had "done in" his fortune, a certain allowance had been arranged for him by his trustees; but, bless you, he found it impossible to keep within the allotted figures thereof; consequently he was always " on the rocks." He happened to be on the Riviera one winter, where, finding himself cashless, he resorted to a very primitive and foolish method of supplying the deficiency. He proceeded to Nice where he obtained certain valuable goods on credit, which, when delivered, were handed over to Mon Oncle at Le Mont de Piêté, in exchange for a wad of " mille" notes. This escapade led to his arrest, and eventually to his incarceration in a French prison. Whilst on remand, our mutual friend Day (one of the "Daddies" of the pigeon-shooting cult, who was a 
kindly, if gruff, soul) visited the prisoner at Nice. The latter was shown into the reception-room wearing a black cape and hood which concealed his features. Before Day could say a word, Benzon shouted out excitedly:

"Hulloa, Day. Who won the Grand Prix?" (meaning the great Monte Carlo pigeon-shooting event).

The indomitable sporting afflatus was still alive. The last I saw of this " curiosity" was at Romano's. He had then grown fat and flabby, but not, I think, from excess, for I never remember to have seen him the worse for liquor. In fact, as regards indulgence in the three lethal W's, "Wine, Weeds, and Women," he was moderation personified; but nevertheless he died at a comparatively early age. Those who regretted him most and who remembered him with kindliest feelings, were those who had benefited least by his wild gambling and lavish generosity. R.I.P.!

There is an erroneous impression extant that " Tod" Sloan was the first American jockey to exploit the " monkey crouch" in this country. As a matter of fact, it was introduced by a compatriot of his, one Simms, a mulatto or quadroon, who won several races and attracted considerable attention, owing to what was at that time considered an extraordinary seat. But even before Simms there was an inconspicuous amateur who adopted the "crouch" in a modified 
form. As late as $192 \mathrm{I}$ a leading sporting paper published a par in words to the following effect :

"An old race-goer says " that Harding Cox had the worst seat and the best hands of any jockey he ever saw. Cox was "crouching" before Sloan, or even Simms, was ever heard of." " And this is a fact. When hunting, I rode very short, and leant well forward in my seat. When racing, I found that by so doing I avoided, to a certain extent, wind pressure, which even in a twomile hunters' flat race is very obvious to the rider. By accentuating this position, I discovered that my mount had the advantage of freer hind leverage. Perhaps that is why I managed to win on animals that had been looked upon as " impossibles," " back numbers," rogues, and jades. My theory was endorsed by Tod Sloan himself. I had been brought into touch with the little man soon after his arrival in England, and, being greatly interested in his methods, I cultivated his acquaintance.

One day, when we were seated on the Terrace at Monte Carlo, we discussed the merits of "the crouch." Tod not only discoursed sweetly on the topic, but drew a spirited sketch of a race horse and its anatomy, explaining how the distribution of weight under his system helped the general action of the animal. He went on :

"Say, I figure that this seat has considerable advantage; but it's no cinch for any guy or dud jockey that takes a hand. Believe me, sir, there's nothing to 
it unless you have the whole bunch of tricks up your sleeve. Gee, if you begin monkeying with the proposition you're sure going to get unstuck !"

These words of wisdom from the wizard of the West have been amply justified, seeing what deplorable horsemanship was obvious when "the crouch " came into universal use. Sloan managed to win on horses which had erstwhile been regarded as only fit for cats' meat. Apart from his seat, he had the best of hands, and always seemed to be on most excellent terms with his mounts. The flail-as a means of exacting an expiring effort from a horse which had already exerted its last normal effort to win-was " off the map " as far as Tod was concerned, for he was a genuine lover of horse-flesh.

$\mathrm{He}$ was a manikin of brains, and a keen observer and judge of humanity. It is true that his phenomenal success and the adulation which it involved, caused his cranium considerably to expand; but if you could get him alone and in one of his more reasonable frames of mind, you would discover in him a philosopher and a wit, broad-minded, sympathetic, and with a heart out of all proportion to the body which contained it.

It had been supposed that Sloan's disappearance from active connections with the Turf was due to his being "warned off." Such, however, was not the case.

$\mathrm{He}$ had been indulging in heavy betting on one of his mounts, Codoman, on which he "had a hunch" that he was sure to win the Cambridgeshire.

This was, strictly speaking, against a rule, which, 
if not actually winked at by the authorities, was certainly more honoured in the breach than in the observance by contemporary jockeys. The good thing came unstuck by a narrow margin. Tod not only " dropped a packet," as the saying goes, but was discreetly advised not to apply for a renewal of his riding license. So that he cannot be said to have been "warned off." A distinction with a subtle difference !

When he returned to his native "States" he was on the down grade. I heard of him in "Frisco" as running a billiard saloon, and using the hard and verdant board as his nightly couch. He married an exceedingly bright and attractive little compatriot, to wit, the popular musical comedy actress, Julia Sanderson; but, alas, I fear that he did not ride strictly to orders, for in this case he really was " warned off" in the Divorce Court; or perhaps the boot was on the other leg. I forget !

On one occasion Tod was cantering to the post at Kempton on a mare called Esmeralda II., when that sportive beast suddenly stuck her toes in, in front of the Grand Stand; whereupon the great little jockey cut the most elegant A.O.T. (Artistic Over Turn) as ever was, and passionately embraced Mother Earth, much to the amusement of the crowd.

I have often had occasion to allude to Captain "Roddy" Owen. Many a good story is told of this accomplished soldier and horseman, who was the best of good fellows. 
On one occasion he was riding in a steeplechase in which there was only one other runner. About three fences from home, Roddy's mount "sat down," and, becoming detached from its rider, scampered off out of the course as soon as it had regained its legs, leaving its erstwhile rider disconsolate.

So the latter's opponent went on his own sweet way; but lo! at the next fence his gee refused, and in spite of vigorous persuasion persisted in remaining on the wrong side of it. A stalwart policeman, mounted on a hairy-heeled weight carrier, scenting trouble, had galloped to administer first aid to the disgruntled Roddy, who, seeing what had befallen his rival, immediately commandeered the ponderous steed of authority and proceeded to give chase to his own derelict, which, after an exciting run, he succeeded in capturing. Having changed mounts he turned the base-born gee adrift and hied him back to the racecourse, just as the other guy was making the sixth futile attempt to surmount the final fence. In a flash Roddy was upsides, and then over the obstruction in a twinkling, and although the recalcitrant one accepted the lead, the Captain got first run and landed the race cleverly.

Although Roddy was continuously in the saddle he did not neglect his soldiering. He had the reputation of being an exceptionally smart officer. But on one occasion there was in orders a very important inspection, when our hero's application for leave (usually 
granted freely, because the Mess to a man, including the C.O., usually had its bit on Roddy's mount) was peremptorily refused.

What was to be done?

He had been promised a ride on something " extra good " for a big hurdle race at Kempton. This was a chance that could not possibly be missed; but he sat tight!

When, on the morning of the race, the regiment was drawn up, Master Roddy came on parade riding a new charger, which seemed, strangely enough, to be quite unmanageable, even in the expert hands of its rider.

No sooner did the band strike up the regimental march, than Roddy's mount took charge-bolted, and suddenly receded from view in the direction of the station.

Roddy rode at Kempton that day and won his race all right, to the general rejoicing of all ranks of his corps. The C.O., however, thought it incumbent on him to "tell off" the backslider.

"Captain Owen," he said, "you may be a very capable amateur jockey, but I should advise you to take some lessons in military riding from your sergeantmajor!"

Roddy smiled. "Hope you had a good race, sir!"

"Oh, pretty well, thank you, Roddy, pretty well." Then in an altered tone, "Here, what the devil do 
you mean, sir? I don't know what you're talking about."

It was in I 892 that I hied me to Aintree in hope of killing two birds with one stone, viz. the winning of the County Cup on Trelaske, and witnessing the Grand National. The first consideration failed to materialize by a length, though I was proxime accessit; but I viewed the great cross-country event complacently.

The previous evening, after racing, I came across Roddy and offered him a lift in my carriage-there were no cars in those days-back to the Adelphi, Liverpool, where we were both staying.

"Thanks, Cockie," he said, "but I won't ride. I'll shove on a sweater and just hang on behind. I'm 2 lbs. above weight for to-morrow (he was to ride Father O'Flynn at Io stone $5 \mathrm{lbs}$.), that ought to do the trick." And sure enough it did, for he was in a profuse sweat by the time we reached our haven of rest. After a bath and a rub down he found to his joy that the " too solid flesh" had melted, so that on the morrow he was able to do the weight easily, and, what is more, to win "the Blue Ribbon of the Leppers" in gallant fashion, as history relates. Of course I backed my friend's mount " each way," and packed up a nice little parcel.

Poor Roddy! his was a squalid end; for, all too young, he contracted cholera when on military service in Egypt, and perished miserably. "Truly a very gallant gentleman!" 


\section{CHAPTER XIX}

T THEN I am asked what are the most thrilling finishes I have ever witnessed, three heroic struggles, which stand out conspicuously, leap to my mind.

The first of these was the desperate set-to between Melton and Paradox, in the Derby of 1885 . The latter had won "The Guineas," in which Archer was his pilot; but when it came to the great Epsom event "the Tinman" was on the back of Melton, whilst Fred Webb steered Paradox. The twain ran locked together from the distance, and curiously enough, in the centre of the course, instead of under the far rails as is generally the case. Horses and jockeys were of the best quality, and the issue was fought out to the bitter end.

It has been said that Archer could have won on either, but Webb could not go on without his horse, and it is probable that Melton was, on that particular day, the better racehorse of the two, though by the narrowest possible margin. It is certain that Paradox lacked nothing in the way of jockeyship. I was so engrossed in the struggle that I did not see the rest of the field, and whenever I try to visualize the scene, it always recurs 
to my mind's eye as a match in which no other runners had any part whatever, a strange delusion which repeats itself when I recall the brief but exciting rally between Ormonde and The Bard in 1886.

Both these faced the starter as holders of an unbeaten certificate. The latter had commenced his career by taking the Brocklesby Stakes. Very few of those that figure as winners of this early juvenile event have greatly distinguished themselves in after daysDonovan, Semolina, Simonian, and Jest being some of the exceptions-but The Bard went on from one success to another-nine wins in all, I believe-before he met his Waterloo in the Derby. On the other hand, Ormonde had only been out three times. As a twoyear-old he had won the Criterion Stakes and the Dewhurst Plate at Newmarket, and had signalized his reappearance the following spring by "slamming" Minting, Mephisto, Saraband and Co. in "The Guineas," as if they had been a lot of hacks.

I shall never forget Matt Dawson's face when he saw "The Boy in Yellow" draw away from the violet and white of Mr. Vyner, as carried by Minting. "Well, I'm blessed !" he exclaimed. "I thought I had the best I ever trained, and quite unbeatable; but mercy on me! what sort of a colt is this fellow of John's ? " (Porter's).

But to return to The Bard. My kind friend and patron, Lord Chaplin, once publicly stated that, in his opinion, this was the handsomest racehorse he had ever 
seen. I am afraid I cannot agree; true the roanchestnut was well knit, symmetrical, and full of quality, but he was only a little chap after all, and lacked the impressive grandeur of some of his kind.

Watching the race for the Derby very carefully, it seemed to me that, just for a moment, Archer had to shake up Ormonde in order to stall off his diminutive rival, and this view the jockey endorsed when I asked him what he considered was the greatest racehorse he had ever ridden. His answer was in words to this effect:

"It is hard to say, sir, but it is between St. Simon and Ormonde. I did have to ask the latter a little question when we were alongside The Bard, but St. Simon was never out of a hand canter in any of his races. Still, I should not like to say he was a better horse than Ormonde, who had some very hot stuff to beat, whereas St. Simon I doubt was ever up against anything extra special."

But I am not quoting the Ormonde-The Bard incident as an example of a real nerve-racking finish, for once Ormonde's great stride had asserted itself the race was all over. By the way, I think there must be something unlucky about the pronoun "The" as regards The Derby. I believe I am right in stating that no horse with that prefix has ever annexed "The Blue Ribbon." The Bard and The Baron failed, whilst, alas, The Tetrarch yielded to the exigencies of training before he had a chance of demonstrating 
whether he could, or could not, stay the Derby course. The contingency is certainly open to argument if not to doubt.

But Ormonde figures in the next of my "specials." Having won the Derby, he went to Ascot and carried off The Hardwicke Stakes with 8 stone $8 \mathrm{lbs}$. up, and the following year, although by that time a confirmed roarer, he again contested the race, in which he threw down the gauntlet to his great rival Minting, the popular idol Bendigo, and an animal of Noel Fenwick's, called Phil.

On this occasion Tom Cannon, senr., had the handling of the Duke of Westminster's champion, whilst Johnny Osborne was " up " on Minting. Here, again, after a cursory glance at Bendigo, for the sake of Auld Lang Syne, my attention was riveted on the two giants. From the Swinley corner it was a case of six of one and half a dozen of the other. The excitement was intense! First a subdued murmur, then a distinct hum, and finally a roar came from the crowd, as it was seen that neither horse could get away from the other; and so they ran from the distance, locked together, to the accompaniment of frantic shouts and gesticulations. I was, happily, so placed that I could anticipate the judges' verdict, but I dare venture to assert that half the crowd thought that the two zeros * would be hoisted side by side.

Now, when it is considered that the Hardwicke is * Signifying a dead heat. 
run over one of the severest one and a half miles in the country, and that poor Ormonde was by then terribly afflicted in the wind, it will be realized what a tremendous flyer he was in every particular. No horse, unless possessed of unflinching courage and perseverance, could have thus triumphed over such a smasher as Minting, who the following Spring carried Io stone to victory in The Kempton Jubilee, and, what is more, galloped clean away from a big and representative field.

My third nerve-twister occurred at Sandown in I903, when the great and glorious Sceptre, Ard Patrick (the Derby winner of the previous year), and Rock Sand (the then latest winner of the world's greatest race) were in opposition. In the paddock the Oaks heroine and Derby hero of I 902 quite threw into the shade the last named, who appeared mean and undersized in comparison with the slashing four-yearolds.

There is a well-worn aphorism which says, "handsome is as handsome does." In this case handsome is did it handsomely, for poor little Rock Sand had to be content with a view of the tails of his giant rivals from start to finish. Madden rode Ard Patrick, and Frank Hardy Sceptre. Without in any way challenging the efficiency of the latter jockey, those best qualified to judge all agree with me that it was Madden's supreme effort which landed Jack Gubbins' handsome colt a winner by the shortest of heads. When I state that Hardy had been far from well for some time before the 
race, his effort to stall off the more powerful Madden did him infinite credit.

Incidentally I may mention that I was one of the first to recognize Madden's merits, when as a stable lad his mounts were few and far between. I think I must have had some faculty for scenting out likely but inconspicuous lads, who frequently became "fashionable" jockeys, such as (in addition to Otto Madden) Walter Bradford and T. J. Calder, some of whose earliest rides were when garbed in my green. In fact Bradford made his début therein.

It was in the Northamptonshire Stakes, in which I was running Armada. I had expected his usual jockey, Allsopp, to be available, but at the last moment he was engaged for Silver Ring (I think that was the filly's name) by "Leo" Rothschild, who had first claim on his services. I was in a fix, when Fred Webb offered to help me out of the dilemma by producing a midget apprentice, who looked as if you could put the whole of him, with the exception of his knowledge box, into a pint pot! I had my doubts, as Armada was given to catching hold. However, as Webb assured me that his little box-o'-tricks could thrash any lad, no matter what his weight, in his (Webb's) stable, I accepted the offer faute de mieux, but was not over-happy, because I fancied my horse not a little, and had supported him freely " each way."

Then came the question of breeches, boots, and colours. Allsopp had not brought his set, but Prince 
happened to have one of my own with him-my size ! Webb's breeches came almost to the child's chin, and his boots were like unto the seven league leathers of Jack the Giant Killer. They had to be strung to his waist by pieces of cord; whilst my cap almost extinguished him, so much so, that when he was being weighed out, old "Ben" Loates called out, "Now then young shaver, come out of that cap. I know you are in it ; I can see your toes sticking out !"

Well, Armada was kept well in hand by the boy, and it was not his fault that my colt was baulked by a horse falling in front of him at a critical moment. As it was, the tiny jockey gathered Armada up and made a clean jump over the prone steed and his rider, but he just failed to get a place. Afterwards, as I have already chronicled, Armada lost the Great Metropolitan owing to a most exasperating piece of carelessness on the part of his rider, who on that occasion was not Walter Bradford, who turned out to be one of the cleverest, most intelligent, modest, and charming of the riders of his day. He was always a great favourite of mine.

A propos Ard Patrick and Sceptre, the great struggle for "The Eclipse," when both were four-year-olds, seems a pointer to the opinion, which has been so freely expressed, that the mare should have been much nearer to winning the Derby than she was. No one was more surprised and disappointed than the owner at her moderate showing in that race. That she was one of 
the most brilliant mares that ever trod the turf there is no gainsaying. I had backed her for "The Derby" with great confidence, but happened to meet the Prince of Wales in the Club. H.R.H. greeted me with, "Well, what have you backed?" When I told him he shook his head. "I think you are wrong; Gubbins tells me that his horse (Ard Patrick) is sure to win!"

Now I had not seen my friend "Jack" that morning, but we were fellow clubmen of long standing, and he was ever ready to give me " the office." However, I laid off on his horse sufficient to cover my investments on Sceptre, and for this "save" I had to thank the then Heir Apparent. Although I did not get "the goods " direct from the owner on this occasion, I had once a straight tip from Jack Gubbins, which brought greatly appreciated grist to my financial mill, though I had to pay top price for it!

I was discussing the great game with my genial Irish friend and his bosom pal Ralph Palliser at that now defunct but once popular "pot-house," The Raleigh Club (Peace to its precincts !), shortly before "The Guineas" of I 897, when the former, following the Hibernian habit of answering one question by asking another, in reply to my query as to Galtee More's chance of winning the first of the classics, asked, "Would you be backin' Kilcock if he were in the race?"

"What, at weight for age ?" I queried. 
Gob !"

"Weight for age? Aw no! Even weights, be

Now Kilcock, then a four-year-old, was about the smartest miler of his day.

"Why, you don't mean to tell me__?"

"Faith and I do, me bhoy; ut's the treuth I'm tellin' 'ye,' is it not so, Ralph ?" appealing to his fidus Achates.

The ponderous Palliser signified his endorsement of the startling intelligence. This was good enough for me! I backed Galtee for the race in question, "Accumulated " on "The Derby," and completed a useful, if not very prolific, treble, when that gallant steed annexed the third and last jewel of "The Triple Crown " on Doncaster's Town Moor.

Galtee More, who was by Kendal (said to have been the only horse that ever got his head in front of the mighty Ormonde's -in a home trial, be it stated), was never beaten in public. I have been trying to think of others in my time that hold a similar record, without counting two-year-olds, who won a race or two and then disappeared from the scene. At the moment I can only recall St. Simon, Ormonde, Polar Star, Barcaldine, Suspender, Galtee More, Hurry On, Kincsem, and that wonderful colt The Tetrarch. The last named, it is true, ran only as a juvenile, but had a brave string of victories to his credit, with one exception all gained with consummate ease, the said exception being in The National Breeders' Foal Stakes at 
Sandown in I9r3. On this occasion "The Spotted Wonder," or "Rocking Horse," as he was sometimes called, reared on end as the tapes flew up. This lost him several lengths, but such was his great stride and terrific speed, that he was able to make good, though only by a neck!

There was a general bewailing when, in the following spring, it was announced that Captain McCalmont's flyer had done his last gallop. That same expansive stride was his undoing, for when at full stretch he was apt to strike one of his fore-fetlock joints with his hind hoofs, so that in the course of time the inevitable happened and the British public saw their idol no more.

There were those at that time, and now there are more, who declare that The Tetrarch would under no circumstances have won the Derby. Their argument was that no colt with such phenomenal speed could possibly possess stamina sufficient to enable him to stay the Derby Course. Now, without admitting the cogency of this theory, I myself have reason to doubt if, had he run, The Tetrarch would have triumphed at Epsom. My reason being based on his pedigree, not so much on the side of his sire, Roi Herode (for the Le Samaritain, Le Sancy line of "Greys," could be depended upon to stay a mile and a half, and often up to two miles), but because there is a blemish in the escutcheon of his dam Vahren, who was out of Catania - a daughter of Rose Garden - the dam of my brilliant but non-staying Dornroschen. Catania never won a 
race, and Rose Garden was little more than a pony. Dornroschen was by Prism (a son of Speculum), a remarkably handsome horse, but only a sprinter ; whilst Catania was by Speculum himself ; and though it may be urged that the substitution of the father for the son should have ensured stamina, the fatal female line betrays the weak spot which caused the eighth furlong of the mile to be a sore trial and tribulation to Dornroschen, and one which more than once proved her undoing. It is therefore possible that her " nephew" may have inherited a similar failing.

This supposition is emphasized by the fact that The Tetrarch's son, the brilliant Tetratema, was one of the Dornroschen kidney. He could " catch swallows," as the saying goes, at six and seven furlongs, and though he did manage to win "The Guineas," it took him all his time to peg back Silvern, whom he could have lost over a shorter cut. Rose Garden was by Kingcraft (winner of the Derby, I 870)-Eglantine by Hermit; a pedigree which does not suggest lack of stamina ; but the kink must be there or thereabouts; though it may be due to some remote atavistic influence.*

There are many cases of great racehorses which have been beaten but once. Two conspicuous examples are

* Since these remarks were written two sons of The Tetrarch have won the St. Leger-to wit Caligula (1920) and Polemarch (1921); whilst another son, Chand, won an important $2 \frac{1}{4}$-mile race in France, besides several big lepping events over a distance of ground. So it seems as if the suspicion of lack of stamina in "The Spotted Wonder's" stock was ill founded. 
Isonomy and his son Isinglass. I was near to writing down the former as one of the select order of the undefeated, but then remembered that though he won the Cambridgeshire in I 878; the following year, carrying a prohibitive burden, he could do no better than register "a place" in a field of thirty-one runners, when La Merville won. Isonomy was undoubtedly a great horse, one of the greatest ever seen on the Turf. The last glimpse I had of him was when he was sent up for sale to-of all places in the world-Albert Gate!

To begin with, he was not a great success as a sire; but as time went on he altered that, and has become a veritable pillar of The Stud Book. His son Isinglass, who was a triple-crowned hero in 1893 , was likewise defeated once, and once only.

He was a great, good-natured beast that delighted in making a race with anything ! I think he must have derived some telepathic amusement by racking the nerves of those supporters who were not aware of this idiosyncrasy. Tommy Loates was his usual, maybe his only, pilot, and he understood the hefty bay thoroughly. In nearly every race the horse ran, the cry would go up "Isinglass 's beat!" when Tommy was seen hustling Mr. McCalmont's steed for all he was worth (apparently); but, Lord love you ! not a bit of it! When the psychological moment arrived, or when it suited his fancy, the " bit up the sleeve" would pop out, and in a few strides the race would be won! 


\section{CHASING AND RACING}

I had a long innings on the turf, not only as an owner and rider, but as an onlooker. I have been asked on many occasions to name the best horses and mares which I have seen performing in public. Here is my list, which I may term my "XIs":

Classic Colts :

Ormonde

St. Simon

Galtee More

Foxhall

Isinglass

The Tetrarch

Persimmon

Ard Patrick

Minting

Flying Fox

Orme

Reserves :

Merman

Bend Or

Sunstar

Spearmint

St. Frusquin

N.B.-I never saw Barcaldine or Isonomy run; but they are always held to have been veritable smashers; though Barcaldine was a wayward and ill-tempered one.

I have not placed these in the order of what I consider their respective merit, though had I ventured to do so, the first two named would be bracketed at the head of the list.

"Handicappers" : (some of whom were also cup horses) :

Polar Star

Minting

Merman

Victor Wild

Irish Elegance

Foxhall
Bendigo

The White Knight

Queen's Birthday

Willonyx

Polymelus 
Reserves :

Tristan

Dean Swift

Cup Horses :

Persimmon

Bachelor's Button

St. Simon

The White Knight

Merman

Isonomy

Classic Fillies :

Wheel of Fortune

Pretty Polly

Geheimniss

Signorina

La Flêche

Diadem

Cup Mares :

La Flêche

Lady Rosebery

Laodamia

Corrie Roy

Thebais

Handicap Mares and Fillies :

La Flêche

Comedy

Corrie Roy

Plaisanterie

Tenebreuse

Florence

The Handsomest Horses (Colts) :

Irish Elegance

Ard Patrick

Persimmon

Surefoot

Minting

Prism

Orby's Pride
Tyrant

Tristan

William the Third

Isinglass

St. Gatien

Prince Palatine

Buchan

Tagalie

Kincsem

Sceptre

Kermesse

Memoir

Dresden China

Canterbury Pilgrim

Comedy

Sceptre

Dornroschen

Hackler's Pride

Donetta

Ballantrae

Hammerkop
Glanmerin

Tangiers

Lemberg

Polar Star

Polymelus

Gainsborough 
The Handsomest Mares and Fillies :

$\begin{array}{ll}\text { Pretty Polly } & \text { Corrie Roy } \\ \text { Dornroschen } & \text { Hammerkop } \\ \text { Sceptre } & \text { Comedy } \\ \text { Canterbury Pilgrim } & \text { Laodamia } \\ \text { Geheimniss } & \text { Glare }\end{array}$

These lists would not be complete without naming the ugliest horses or mares that I can remember. "Handsome is as handsome does" is a trite enough saying; but the better looking racers of either sex are generally the better performers. Those of "homely" form and feature, or those who would seem more in place in a Christmas pantomime, are but the exception which prove the rule.

Here are some of them :

The Grafter

Dean Swift

Epsom Lad
Manilado Hurry On

I think The Grafter must be awarded pride of place, for he was a perfect figure of fun! I never saw such a pronounced Roman nose on a racehorse ; and his ears reminded one of those of a prize lop-bunny!

Dean Swift would never have taken the championship at a beauty show. To see him wandering around the paddock was to pity him for his loneliness without the shafts of a four-wheeler to hold him up ; but what a splendid fellow he was on his favourite coursesEpsom and Ascot! I always couple Dean Swift and Victor Wild in my mind as prototypes, for the latter was by no manner of means an " oil painting " (though 
not quite such a scare-crow as Mr. Jack Joel's beloved steed); but, like the last-named, he had his special fancies in the way of tracks, these being Kempton (where he won "The Jubilee" in 1895 , carrying 8 stone $4 \mathrm{lbs}$, and also the following year, when he repeated his triumph, carrying no less than 9 stone 7 lbs.) and Hurst Park, where, in the Cup, he was victorious in 1893 , and again in 1894 ; on each occasion being hunted home, as previously stated, by my Dornroschen, who, on the first occasion, was conceding him no less than 9 lbs.!

Both these horses picked up races elsewhere, I believe, but were never seen to such advantage as was Dean Swift at Epsom and Ascot, and Victor Wild at Kempton and Hurst Park, as quoted.*

Epsom Lad was another " comic cut" who could go fast and stay, and who was endowed with any amount of grit, as exemplified when he won "The Eclipse" in I90I, and other important events. At the time of writing, Manilado is still in training, and has done fairly well on occasions; but from an ocular point of view, he is no credit to his illustrious brother, Gay Crusader, and his near relative, Gainsborough, both of whom, and especially the latter, were " picture horses."

* Victor Wild also won the Royal Hunt Cup in 1894, when, as a four-year-old, he carried 7 stone 7 lbs. ; whilst Dean Swift won the Coronation Cup as an aged horse at Epsom in 1909, with 9 stone 3 lbs. up. 
Hurry On, one of the select group possessing a record which chronicles no defeat, was, in his racing days, a big, rough-and-ready customer, possessing some excellent racing points and lines; but he had $a$ head and a half, of the "fiddle" formation. When first he unveiled himself under colours he was whispered as something trés chaud; but a knowledgeable friend of mine, on casting an eye over him, said with a shrug, "Well, if he can carry that head all the way and win, I'll eat him!" $\mathrm{He}$ did win all right; but, of course, my friend was not permitted to devour him, even had he acquired a sufficiency of appetite to do so!

I did not see Durbar II., the French colt, who took down the numbers of our native champions in the Derby of I9I4 (the year of dreadful fate !); but I am credibly informed that he was a perfect eye-sore! $\mathrm{He}$ won pretty easily, but beat one of the poorest fields in point of class that has ever contested the great race.

To go to extremes, I must hark back to the Apollos of the equine world. I have no hesitation in awarding the palm to Irish Elegance, a truly marvellous specimen of a thoroughbred, such as even the most carping of critics would find it hard to "fault."

Next I should name Surefoot, one of the handsomest of all time, but a hooligan of the deepest dye, whose bent lay more towards Venus and Mars than 
towards the wing-footed Mercury; though when he took it into his head to pay attention to racing, rather than to savaging others, he took a deal of beating. That he could have won the Derby of his year is practically certain, had he not been seized with an overwhelming desire to make a meal off an unfortunate rival who came within reach of his teeth, and in so doing seemed to forget what the order of the day was. This was in 1890 , when Sainfoin won. The following year, after a most astonishing display of erotic irresponsibility in the paddock at Sandown, Surefoot was induced to win The Eclipse, by the use of his heels (laid to the ground and not as was usually the case, against the ribs of a rival) rather than his teeth. $\mathrm{He}$ scored in a very tight finish, when the proverbial tablecloth would have covered four of the runners.

Despite Surefoot's constantly recurring and public demonstrations of his amorous proclivities, he was a comparative failure at the stud.

As a third side of the beauty triangle I should name Ard Patrick, with Minting close up.

All these were of the massive and imposing type, yet full of that elusive asset termed quality; so easily understood by judges of horse and dog flesh, and yet so difficult to define or describe. I have seen hundreds of really charming racers of both sexes, built on the medium or small model ; but it would require a very intense application of mind to recall and "place" a dozen of them as hyper-beautiful specimens. Glancing 
at the mares that I have seen run, I have the hardihood to opine that my own Dornroschen was of peerless presence (every one thinks his own crow the blackest !), and that proxime accessit at a beauty show I should place that wonderful, but sometimes disappointing, flyer, Sceptre. 


\section{CHAPTER XX}

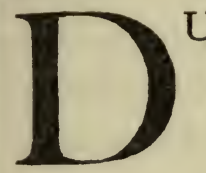

URING the time my horses were being trained by Sam Pickering at Kennett near Newmarket, "Mr. Jersey," whom I had counted among my most cherished friends, off and on for many years, was likewise closely associated with the stable; though eventually she placed her string under the care of Fred Webb.

"Mr. Jersey," or to call her by her real name, Mrs. Langtry, * at that time resided at " Regal Lodge," hard by Pickering's stables. I was a frequent visitor, and shall always remember with profound appreciation the kindness and hospitality which I enjoyed at the hands of "The Missus" (as we used to call her) and her charming daughter, Jeanne (afterwards Lady Ian Malcolm), who at that time was in her "teens." The latter was very sympathetic with me regarding our mutual love of horses and dogs, especially the latter, and also because music appealed to us both insistently ; but whereas I was, and am, naught but a melodist, without much technical knowledge or skill, Jeanne was a trained and facile musician. I would

* Mrs. Langtry eventually became Lady de Bathe. 
play my airs on a silver whistle of the "penny" variety, and she would take them down in music notation, almost as fast as a skilled stenographer can transcribe from dictation.

Her beautiful mother and I had much in common, and were never tired of discussing, not only the absorbing matters of the turf in which we were both so intensely interested, but those of the drama, art, social and other amenities which appealed to us almost as much. When a meeting at Newmarket was toward, open house was kept at Regal Lodge, and lavish hospitality dispensed to those sitting in high places, who were also enthusiasts in the game.

An outstanding personality of the turf, with whom I came in contact at my hostess' residence, was Capt. Machell, at that time manager to the racing establishment of the then Lord Calthorpe. I had many a chat with him and gleaned much useful information in racing matters ; for the Captain was an unerring judge and a keen observer. There came a time when Regal Lodge and its entourage had experienced a somewhat disastrous week, and it behoved us to find a safe "get out." Capt. Machell, taking compassion on our forlorn position, put up a " cinch " for us at Gatwick -a two-year-old called Blackthorn (I think that was its name), which he declared could not possibly be beaten, unless he fell down; and even then might be capable of regaining an upright position and sufficient equilibrium to enable him to slam any opposition that might 
be offered. We all went to the meeting to interview this prodigy, and were introduced to a singularly handsome black colt, whose bearing and manners, plus the whole-hearted recommendation of our astute friend, emboldened us to freely lay odds of I I-IO on in a small field. If I remember rightly, my one-time protégé, Walter Bradford, had the mount, and he "doddled it," winning in a canter by a couple of lengths. Here, thought I, is a smasher, and one to follow religiously. So the next time Blackthorn ran I had a packet on him ; but, to my surprise and pain, he was numbered with the "also ran," and, as far as I can remember, never greatly distinguished himself thereafter.

Now the question arises, how on earth did Capt. Machell gauge the colts' chances in the Gatwick race with such accuracy that he was able to reduce the issue to a gilt-edged certainty, having regard to the fact that the winning card was not an "honour" ? Or was Blackthorn really a top-sawyer when he ran at Gatwick, and did he subsequently lose his form through some untoward circumstance? I am left guessing ! Anyway, we all got home on him (Glory be!), and departed rejoicing and pouring blessings on the gallant Captain's level head.

Sometimes a very Great Personage would honour Regal Lodge with his company at luncheon or dinner. On the latter occasions he preferred a homely little gathering consisting of our hostess, her daughter, a 
dear friend of mine, and myself. A pleasant evening was always to be looked for. Some kind friend had presented the V.G.P. with what was alleged to be a French bull-dog, but which fell far short of the ideal in the matter of points.

Said my hostess to me, "His Nibs is going to bring his dog over to show you and obtain your expert opinion. I don't think it is much of a one, but for goodness sake don't say so!"

All the same I was determined to speak out and say just what I thought of the dog, whose name was Peter. So when the V.G.P., with a look of pride on his popular features, showed me his pet, I told him exactly what the dog's failings were, and what its good points (which were precious few); whilst behind its master's back my anxious hostess was glowering at me and contorting her classic features with forbidding frowns. But she need not have been alarmed, for the owner accepted my criticisms quite meekly, if sadly, and anon walked me out to the paddocks to inspect the stud and to pass my opinion on its units.

When we returned to five o'clock tea several notable Turfites were assembled, and the cup that cheers and often, I believe, does inebriate (in certain feminine instances), was being handed round, and we fell to discussing future events. I remember having a wager with the V.G.P. that Newhaven II. would beat a certain nominee of his in the Ascot Cup, "both to run and one to win," when I became aware that Peter 
was making a devastating raid on the pedestal which displayed cakes, petits fours, and other confections. He was just within the range of my foot, so I administered a gentle correction. The kick was by no means a hefty one, but the revengeful Peter set up a loud lamentation, which immediately arrested the attention of his Royal Master, who exclaimed-

"Why, what's the matter with Peter? Has any one hurt you, Peter?"

I took the bull by the horns! "He was raiding the cakes, sir!" I said, "so I pushed him with my foot. He is not hurt, only startled."

"Now that was very naughty of Peter; but you must not kick him," replied the V.G.P. rather severely.

When the company broke up my hostess addressed me, "You've done it now, Harding (she was one of the few who refused to address me by my pseudonym'Cockie '). You'll be outside in a pot hat now !" But she was wrong. I was still in quite good odour with royalty.

Sometime later-at the Newmarket First Spring Meeting of I898, I think-H.R.H. the Prince of Wales, as he then was, joined our group on the lawn, with the pleasing information that he had "a real good thing" for us, emanating from Dick Marsh's stable, and owned by Mr. J. W. Larnach-one Jeddah to wit. "He is sure to win this Triennial to-day," declared H.R.H., " and then he will be favourite for 
the Derby. Now the thing to do is to back him for the Derby before he runs." Then turning to me, "What can you get?"

"I don't know, sir, but I'll see," and off I went to the ring, soon returning with the information that Ioo-8 could be booked for the great race; whereupon the Prince said he would have $£ \mathrm{r}, 000-£ 80$. Mrs. Langtry declared for a like wager, and I determined to take the odds for myself. One of these ventures were entrusted to Geo. Cooper (the best of bookies, and one of nature's gentlemen), and the Daily Mail hatted Rob Lee, respectively; but I forget who the third victim was. Reuben Sassoon booked the bet for H.R.H. Came that day's race, and Jeddah well down the course! We looked unthinkable things at the Heir Apparent, but he only shrugged his shoulders, "I cannot understand it," he said; "they told me Jeddah was sure to win!"

"Does not look much as if he would win the Derby, sir," I ventured.

"No, I suppose not !" and H.R.H. strolled away, followed by the faithful Reuben. When "off" had been signalled in the great race of 1898 I was in Mrs. Langtry's box. I forget what we had backed, but it was " not on the map " as the field swept round Tattenham and were pounding down the straight. "We're beat," murmured my hostess. "What's winning? How about Batt?" (the Duke of Westminster's representative). 
" Going well; but there's one going better. Here ! what price Jeddah? Jeddah wins ! -Jeddah!"

" That's a crusher," mourned Mrs. Langtry. " A skinner for the ring. Every bet I had has gone down!"

"Not every one, Missus. Have you forgotten that you have $£$ rooo- $£ 80-J e d d a h$, for this race? And so has the Prince, and so have I. Glory be!"

My fair friend jumped up, "Good heavens, you're right, Harding. What luck! Why I had forgotten all about it! Run and tell His Nibs, he'll be delighted!"

I found H.R.H. in the Club. Before I could say a word he exclaimed :

"What do you think of that? Here's a horse in our stable wins the Derby at 100-I, and I have not backed it for a shilling!"

"Pardon me, sir," I corrected, " but you have a bet about Jeddah !"

"Why, what do you mean?"

"Don't you remember, sir? I took $£$ 1000- $£_{80}$ for you before Jeddah ran in the Triennial !"

"Why bless my soul, so you did; that's capital, capital. Go and tell Reuben! I hope you won a bit ?"

I told H.R.H. I had, and that all was well.

So ended the Jeddah sensation. At Ascot the horse proved that his Derby victory was no fluke. The fact of the matter is that his inglorious display at 
Newmarket was accountable for by the state of the "going" on that occasion; for it was adamantine, and one could hardly see the field for dust as they ran.

"Mr. Jersey" was an enthusiast in racing as she was in other matters. Whatever her fair hand found to do she did it with all her might, and did it well. She had an idea, and a very well-founded one to boot, that our native racing stock was, taken as a whole, deficient in that all important quality-stamina; that in this respect it was, in fact, degenerate. She had marked the constant and remarkable success of the Musket blood in the Antipodes, and determined to import some of it, with a view to an improvement in our native productions. Her first venture was a highly successful one; for when Merman had become acclimatized he became a power in the land, for, after winning the Cæasarewitch of 1897 (for which he was boldly backed by his owner and her friends, including the writer), he put a seal on his fame by carrying off the Ascot Gold Cup two years later. In the meantime he had been rather unluckily beaten in the Chester Cup of 1898 , which was won by a lightlyburdened outsider named Up Guards; the peculiarities of the cramped Chester Course and the short run in being unfavourable to such a far-striding horse as the "Aussie."

Though not what might be considered a " picture horse," Merman was the possessor of some outstanding 
points of merit. I never saw such a deep and wellribbed chest, nor such long sweeping shoulders. His quarters, if somewhat ragged, were immensely powerful; in fact the whole figure of the horse suggested great strength and staying power.

But "Mr. Jersey" was not so fortunate the next time of asking, when she imported Aurum, a colt of the right strain, whose performances "over yonder" had been most impressive. When he reached this country it was found impossible to train him properly ; moreover, to the best of my knowledge, he never became a success at the Stud.

A notable mare which was left to Mrs. Langtry by the testamentary disposition of George Baird ("Mr. Abingdon") was Lady Rosebery, who contracted the pleasant habit of winning Liverpool Cups, and rounded off with the Jockey Club Cup in 1893 ; her example being emulated by Merman five years later.

"Mr. Jersey" was devoted to her horses, and no matter how badly they cut up or how completely they let her down, had always an excuse for them. My critical faculty sometimes urged me to make remarks which were extremely distasteful to my friend.

On one occasion, after inspecting her string, good, bad, and indifferent, I came out with, "I say, Missus, I wish you would ask me down for a few days' shooting!" "But, my dear Harding, you know I have no shooting to offer." 
"Oh yes, you have; I could enjoy grand sport potting some of your useless and expensive equine rocketers!"

Well, I was fairly "for it," and a lifelong and cherished camaraderie was nigh coming to a sudden and violent end; but happily an abject apology brought about a peaceful issue. There was, however, one colt which sorely tried its owner's patience. At last a day came when it so behaved as to call forth an order which in promulgation provided a particularly neat bon mot.

This colt's name was Amberite. $\mathrm{He}$ was one of those that could if he would, but he almost invariably wouldn't! He was running at Kempton, whither Mrs. Langtry had been unable to go on that particular day. She, however, received a wire at Regal Lodge from Fred Webb (who at that time had charge of her horses) to the following effect : "Amberite beaten, would not try a yard." The owner's reply was-

"Amberite is no gentleman! Make him so!" -Jersey. 


\section{CHAPTER XXI}

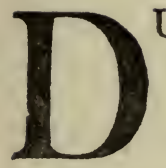

URING the time I disported myself on the Turf as an amateur rider, I was naturally brought into contact, at one time or another, with all the riding knutsmembers of Bibury, Southdown, Sandown, Kempton, Newmarket, and other important clubs; and a nice cheery set of boys they were, who played the game of give and take to perfection.

Those who were genuine contemporaries were linked up with a senior bunch, units of which took occasional mounts when conditions and circumstances were favourable. Among the latter Arthur Coventry was conspicuous. In his day, he had been looked upon as facile princeps, and he never lost the art of race-riding. When he became official starter to the Jockey Club it was not often that he donned silk; but when the Bibury Club Meeting (then held at Stockbridge) came round, he was generally to be seen on the back of some gee, owned and trained by his friend, the local celebrity, Tom Cannon, senior. On these occasions I frequently found myself in opposition. I tried to tackle him on one of the great ex-jockey's string, with my non-staying and delightful, but elephantine Blankney. 
The race was a mile, but my joker had no pretensions to stay the distance; he nevertheless held on for seven furlongs before giving Arthur's mount best, and was well in front of the rest of the field at the finish.

A day later I slammed the same rider (when vainly endeavouring to induce Tom's champion Blanc to show a shadow of the form he had displayed in a home trial) with my Dornroschen, as described elsewhere; and on the last day's racing I had my revenge on the Cannon contingent in a six-furlong race, which was eminently to Blankney's liking. Incidentally I may mention that this was a selling race, and I was fearful that I should have to soar into high finance, in order to retain the dear old chap ; but as luck would have it, he had twisted a plate in pulling up, with the result that he limped around the sale ring like a lame duck, so no one would bid.

I have already described the tight finish between Arthur Coventry, Geo. Baird (Abingdon), and myself at Derby. I was indeed fortunate to be on the better gee three times out of the four that I encountered the first named.

If I was lucky as regards the two named, and Sir James Duke, there were others who were veritable hoodoos to me. Not once did I succeed in pegging back Tommy Lushington; though on one occasion I got to the head of his mount on the post, when riding the worst rogue that it was ever my ill-fortune to bestride. This was Roscidus, alluded to earlier in 
these ramblings. Tommy was built on the same lines as myself, that is to say, decidedly " stocky," with short legs, but lots of power in back, loins, shoulders, and arms. He had the best of hands, a thorough knowledge of pace, and fine judgment all round. In fact, I rank him as one of the most efficient amateurs I ever came across.

Another that was constantly taking my number down was W. H. ("Bill") Moore, a brother of the delightful "Garry" of that ilk, who was himself a perfect performer over the sticks and between flags. Bill was the antithesis of Tommy Lushington-a long, limber chap and immensely strong. One wondered how on earth he managed to go to scales at the weights he carried. He looked as if he walked twelve stone! And yet he could ride (all in) eleven stone or thereabouts. He was the most powerful finisher of our bunch ; but a cruel one.

Of George Baird I have already said sufficient to show what an accomplished horseman he was at his best; but admittedly his living was not what one might term ascetic or even prudent. Towards the end of his riding days his nerves were anything but strung to concert pitch.

Two soldiers, who had been schoolfellows of mine at Harrow, were notable performers. I allude to Major "Bobbie" Fisher and Capt. (afterwards Colonel) Childe. The latter was known at the Schoolon-the-Hill as Childe-Pemberton, but latterly he 
dropped the affix. He was killed in the Boer War in one of the early battles (Grasspan, I believe). A simple stone was erected where he fell and was buried, inscribed : "Is it well with the child? It is well !" If I have not the line verbatim, pray excuse me. The sentiment is expressed correctly.

Of Roddy Owen I have written copiously. Those who knew and appreciated him will ever bear him in affectionate remembrance and deplore the horrid calamity which put a premature end to his joyous, devil-may-care life.

Lord Rocksavage. (afterwards Marquis of Cholmondeley), better known as "Rock," was a very capable horseman and an excellent judge of racing. $\mathrm{He}$, like Bill Moore, was very deceptive where weight is concerned, for he was not nearly so heavy as he looked. He was a man of taciturn disposition, who, like the sailor's parrot, thought much and said little. $\mathrm{He}$ always gave me the idea that he wanted to snub me or to ignore my existence; but when it came to correspondence, he was most courteous and informative.

The Earl of Derby rode occasionally and with some success. I think I have told how my dear old Weasel passed into his hands, but I am not sure if he won a race with him or not. "Chris" Waller, Teddy Wilson, George Lambton, Wengy Hope Johnstone, Ronnie Greville, Percy Bewicke (quite Ar), Charlie Cunningham, Dan Thirlwell, “Mr. Charles" (Lord 
Molyneux *), were others of my time who made good; whilst such as Ronnie Moncrieff, Guy Fenwick, Alec Popham, and Major Morris occasionally popped up. But I must not forget Major Frank Atkinson, a standing dish at Lewes and successful elsewhere, a very live proposition indeed, and one who could hold his own with the best.

George Thursby began to blossom out just as I was fading away from the Turf; but we overlapped a bit, as already described. All things considered, and when his powers as a horseman were fully developed, I have no hesitation in pronouncing him the best amateur rider that ever came under my observation. There were few, if any, professionals that " had anything on him," as the American slang has it !

A good many of those whom I have named held, like myself, the advantage of a license from the Jockey Club to ride on equal terms with jockeys, so that occasionally we met in a " mixed" field, with the consequence that we amateurs had an insight to professional characters and methods which were hidden from the public. For my own part I can bear witness to the fact that the rumours and scandals which overshadowed "the little men" were for the most part entirely without foundation, or preposterously

* Lord Molyneux was a capable and cheery amateur who came to a sad end. After sustaining a terrible crumpler at Sandown, his spine was so affected that he was two years on his back before death ended his sufferings. 
exaggerated. But, of course, there were black sheep in the fold, and no doubt some very clever and daring ramps were occasionally engineered. Taking them all in all, I found the professional jockeys a respectful and respectable lot, though there were one or two whose heads appeared to have swelled to such an extent that they had to take the largest sizes in racing caps. These exceptions were apt to be dour or cynical. No doubt the instructions which were hammered into them to keep their mouths shut and their ears open, may have accounted for their mauvaise honte, and their churlish manners.

Personally, I appear to have enjoyed a full measure of popularity among owners, trainers, and jockeys ; consequently I was favoured with a plethora of " tips," which often left me in a dilemma as to what horse I should support in a particular race.

For instance, I invested on five horses in the Cambridgeshire of 1893 . At the last moment Bob Sherwood told me that I must not leave Molly Morgan out of my calculations; but she had let me down in the Cæsarewitch, and I would have none of her. My "bunch of five," headed by Raeburn, followed "Molly" home without any interloper intervening!

One day I met Humphries (who was then training for the Thursbys) in Piccadilly. The genial one invited me to his Club (the newly-formed and palatial "Junior Constitutional "), and there he confided to 
me that he was sending a string of five to Newton, and expected to win a race with each one of them.

"I believe you are fond of dabbling in accumulators," he said. "Here's your chance, Captain, to pack up a parcel."

I took his advice, and coupled up his lot in doubles and trebles in all sorts of combinations.

It was the time of the 'Varsity Cricket Match, a contest which I never miss if I can help it. At my best I was only a third rater with leather or willow ; but I love the game, and consider myself a fair critic thereof.

Well, I kept buying evening papers as each issue was published and distributed. Sure enough Honest John's little lot " clicked" monotonously, with only one exception. What was due to me was quite beyond mental calculation. I was, naturally enough, elated at first, and so was a dearly beloved friend who was with me.

"Cockie, dear, this is splendid!" she enthused.

A dead weight fell on my exuberance.

"Yes, sweetheart, a great deal too good, I'm afraid," I answered gloomily. And I was right! My presentiment proved miserably well founded, for my S.P. merchant "did a guy" and "beat it," as the Yanks say, and I was left lamenting! I had won over $£ 3000$ (and no single bet over $£ 5$ ), and all I could lay hands on was a bare deal table and a rickety chair, left in the 
once sumptuous office of the absconding "commission agent."

$\dot{A}$ propos accumulators, it happened that I was witness of a rather extraordinary gamble which took place on the International Gun and Polo Club shooting ground at Hendon. A young "sport," whom I will call "A.," asked a rather green but self-assertive competitor, "B.," if he would accept " a fiver" and let him, A., have a penny accumulator S.P. on all the winners at Epsom (the Spring Meeting had just commenced). B. "fell for it" readily enough.

It so happened that all the winners that day were at a fairly short price, and when we met next morning on the pigeon ground $B$. found himself over $£ 3$ in pocket; but A., quite undaunted, said, "You've bested me this time, B.; but look here! I'll give you ' a tenner' to have a penny accumulator on all the winners at Epsom to-day." B. rose like a famished trout. When we had assembled for the final day's shoot, (incidentally I may be allowed to brag that I won the Cup), B. strolled up to A. "Hulloa, A.," he said, " how does your penny accumulator work out to-day, old sport? I had not time to look at the returns ?" "Oh !" said A., calmly, removing his cigar from his lips and knocking the ash off on the stock of his gun, "I make out you owe me $£ 43232$ s. $3 d$. !" (these were not the exact figures, but they are approximate, and serve to accentuate the astounding result). Of course B. was flabbergasted. For the moment he tried to 
bluff and to laugh off his predicament as a kind of joke ; but a bet is a bet, and he had taken his chance. It seems that hardly a favourite had won on " the Downs," and most of the winners were of the "IOO- 8 " or "20-I others" category. I believe that the wager was in the end settled for a matter of " a monkey." 


\section{CHAPTER XXII}

T $\mathrm{HO}$ that goes down to the racecourses in trains, buses, motor cars, traps, or on Shank's mare, has not heard of wonderful dreams of winners-and losers?

Some of these hallucinations are really remarkable. It fell to the writer's lot to experience a most astounding somnolent forecast; one which turned out highly profitable moreover.

It was in I892, and the eve of the Jubilee. I had been carefully studying the handicap, and had reduced the number of those horses which, to my way of thinking, were "possibles" to half a dozen, but could not make up my mind as to which of these held the winning card. I went to bed in the nuptial chamber and dreamed a dream.

I was, methought, in the members' enclosure with Ted Jaquet, who has figured so largely (metaphorically and physically) in these pages. The field cantered to the post, and I essayed to take up a point of vantage to view the contest, but found myself so crowded in that I could not move. Ted was more lucky, and I could see his expansive and genial dial beaming above 256 
the heads of packed humanity. When "off" was signalled on the brazen bugle I shouted to my cousin : " D__ it, Ted, I'm fixed here; what's happening? What shall I back?" His reply came clear and concise, "Back Euclid; he got off well and is nicely placed on the rails!"

"Take you twenty-two ponies Euclid," I yelled to Fry, who was within earshot.

"Lay you twenties, Capting," came the leviathan's reply.

"Not good enough!"

Then from Ted-

"Take twenties, Cockie, take any price. Euclid is going better'n anything. He'll win!"

"Take you twenties to a pony, Fry!"

"Too late, too late, Capting! they're near home now. Lay you eights!"

The yelling and shouting began, and presently the field flashed by. I could see nothing but the caps of the riders. Then there was a sudden hush as the numbers were hoisted.

"What's won ?" I asked a guy who was squeezed against me.

"Look at the number board, guv'nor!" was the non-committal reply.

I could see the erection all right, and hoisted in the winning slot a big and conspicuous " 9."

"What's 9 ?" I asked.

"Look at your card!" 


\section{"But I haven't got a card !" Then I awoke!}

The whole dream was of the greatest clarity, and the incidents positively meticulous. There were none of those absurd complications and transformations which, as a rule, render dreams as the hallucinations of a lunatic, or the observations of a victim of D.T. I was fully awake. I got out of bed and scribbled on a slip of paper, " Euclid, No. 9." I looked at my watch, it was 3.35 a.m. The race was due to be run at 3.30 p.m. Then I returned to bed and fell into a dreamless slumber.

Next day on arriving at Waterloo station en route for Kempton, in feverish haste I bought and scanned the card. Euclid WAS No. 9!

I entered the train, and the first person to greet me was " Nigger" Duncan, Euclid's owner. I told him my dream. "Well, I fancy the little horse," he confided, " and have backed him ; but on the strength of your dream, old Cockie, I shall have another hundred on."

As all the world knows, Euclid won; but I was not hemmed in ; on the contrary, I had an excellent view of the race, and incidentally enriched my banking account very considerably.

I must confess that from the time the weights were declared I had a strong fancy for the horse, and his name was among the half-dozen that I had ticked off as likely propositions. Now comes the sequel. 
All my pals at The Raleigh Club knew of my dream and its issue, so when the eve of the companion race to the Jubilee, The Duke of York's, came round, I was besieged by ribald fellows, who urged me to go home, dream the winner, and give them " the office." Well, I did have a dream, but it was not of Kempton or any other racecourse.

I thought I was back at The Raleigh and telling my cronies that I had tried to dream and had failed. " Bad luck, Cockie," said Nat Hone, the amateur S.P. merchant ; "but never mind, do as you did before!" Again I woke up, the hands of my watch were at 3.30 a.m.

Now the answer of the oracle was cryptic, Euclid was in the race, but with a weight at which I did not fancy him in the least. It must be No. 9 on the card, I decided. When that publication was investigated, there was what I imagined to be a further set back. No. 9 was Miss Dollar, trained by Charles Archer, who told me he had not the least fancy for her; but had thrown away " a tenner" just for consistency's sake. I decided for a modest " fiver" on Euclid! Miss Dollar won at IOO-I !

Thus did I place more faith in my personal judgment than on the revelations of a mysterious oracle, greatly to my chagrin and loss!

On one other occasion only have I dreamed of a race. To deal with this I have to go back to the Derby of I 879-a far cry! I had dreamed in phantasmagoria 
fashion that the great race was to be contested by the animal kingdom! It was a "straight run and in." The winning-post was a flagstaff planted in the middle of the course. A polyglot field turned out : lions, tigers, elephants, bears, deer, pigs, rabbits, and what not, including a squirrel, which got a flying start, reached the flagstaff, a distance ahead of the others, ran up it and sat crunching nuts on its summit.

I do not think any one connected with racing knew that such a colt as The Squirrel was entered; assuredly $I$ did not! and yet when the numbers went up, lo! and behold, No. 33 was Mr. Acton's, The Squirrel!

I was a very modest punter in those days; but I had my humble "Jerry o' Goblin" on The Squirrel at 50-I. (Had I known as much as I do now I could have had 500-I.)

Now Mr. Acton was the assumed name of "Leo" Rothschild, so The Squirrel's colours were "Blue, yellow cap," and these were exceedingly prominent on the stand side of the course at the psychological moment. What is more, they were first past the post, and my callow heart rejoiced with an exceeding great joy. Unfortunately for me there was another gee which bore the same resplendent jacket and cap, Sir Bevys, to wit, who afforded George Fordham his one and only victory in the Derby.

The Squirrel had been started to make running for 


\section{CHASING AND RACING 26I}

his stable companion, and he did not wear a distinguishing cap! So that was that !

Incidentally, I may remark that the race of 1879 was run in a sea of mud, and that Sir Bevys was one of the worst horses that ever annexed the Blue Ribbon of the Turf. 


\section{CHAPTER XXIII}

MONG the elder school of jockeys I had good friends in Tom Cannon, senior, George Fordham, and Johnny Osborne. The last named once did me a very kindly service. I was riding in a " mixed" race at Liverpool over the cup course. It is a very short run from the starting-post to the first turn, and there is always a scramble to get well placed thereat. On this occasion I was jammed on the rails, and in imminent peril of going over them, horse and all, when Johnny Osborne pulled out, crying, "Slip up here, sir, quick, or you'll be on the floor!" Of course I acted on the invitation with alacrity, and so avoided what might have been a very ugly accident.

Tom Cannon essayed to do me a bit of good, but in quite a different connection. I was walking in the paddock at Sandown, deep in the study of "Form at a Glance," when suddenly " the Backer's Bible" was sent flying out of my hands. I turned round in wrathful astonishment and found myself facing Tom.

"What's up ?" I exclaimed, as I stooped to recover the volume. "Let it be, squire," said Tom; " if you follow that you'll be broke to the world before you're 262 
much older." Then we had a little argument ; but I have since come to the conclusion that Tom was right!

Of course I was known to, and knew, practically all the leading jockeys of the day, and one time and another most of them rode for me, for I was not one of those favourites of fortune whose exchequer permits of their giving a lucrative "retainer" to their pet horseman; so I had to take my chance of securing the services of any disengaged and competent "jock" on the day of the race toward. When I could get him I had a leaning to "Morny" Cannon, and was a patron of the Chaloner family. George, Dick, and Phil all rode for me. I knew the Loates' bunch. Charles ("Ben ") often sported my "two greens," and I think Tommy did so on one occasion-Sam never! Otto Madden, T. J. Calder, Walter Bradford, and Frank Allsopp (for each of whom I held a very high opinion) were either apprentices, or just out of their indentures, when I first put them up; but all subsequently attained high distinction.

The few horses which I ran over the sticks or between flags were, if not entrusted to my friend, Roddy Owen, handled by Jesse Page, Prince's Stable jockey, or by Arthur Nightingall. "Jesse" was a first-rate artist at the so-called illegitimate game, but he hardly looked it ; for he was round as a little apple, and, like myself, very short from the hips to the knee; nevertheless, he stuck close to the saddle over hurdles 
or fences, and incidentally stuck still tighter to an opponent in a close finish.

I have already described how Arthur Nightingall nearly came to an untimely end when riding my Chevy Chase in the "Grand prix des Haies," at Auteuil.

A good yarn is told of George Fordham, which may or may not have a foundation of truth; but I expect our helpful friend, "Ben Trovato," had something to do with its embellishment. As the story goes, a "little" owner, whose methods were not always of the "Cæsar's wife" class, once persuaded George to accept the mount on a certain plater, whose job looked such an easy one that substantial odds on were sure to be asked for and laid. As in the case of the sporting amateur rider, which I dealt with earlier, the owner, when giving his "instructions" to Fordham, winked the eye of wickedness, saying in effect :

"The horse is not very well to-day. Don't knock him about; I am running him again to-morrow. He will then be as fit as a fiddle, and you can win with him just as far as you like, and back him till the cows come home. You understand what I mean?"

"Oh yes, sir," said George, with a face like a plate. "I know what you mean!"

History has it that the great little jockey cantered to the post, where he proceeded to dismount, gave the horse a cut with his whip, and turned him loose with this admonition : 
" Go home to your master, and tell him that I feared I could not do justice to your form, so thought you would race better without me!"

This is a record of honesty of purpose; now comes the antithesis.

It is related by a certain friend of mine, who also was an amateur rider and owner. Here again methinks that "Ben " collaborated in the output.

The episode is said to have taken place at Ascot, where the said friend (being anxious to see how a colt of his was going, in a mile and a half race, when still three furlongs from home) posted himself at the turn into the straight out of the Swinley Bottom. In the race in question two of the most fashionable jockeys of the day were riding. For obvious reasons we must invent names for them, de mortuis nil nisi bonum, you know! Let us call one " Bud " and the other "Jed" (no, they were not of American nationality).

As the field swept round the turn "Jed" was leading; whilst "Bud" was rather uncomfortably boxed in the ruck. The latter cried out imploringly, “' 'Ere, 'old 'ard, Jed-'old 'ard! I shall never get 'ome by a nob!"

The same amateur, who was an Irishman, by the way, had a good story about a "rookie in racing" from the wild and woolly west of Connemara, who was taken to The Curragh, for a treat, by a sporting pal, who proposed to mark his card with acumen and precision; but Mickey O'Hara, as we will call him, 
being of an obstinate and independent disposition, would have none of the "certs" and "cinches" selected for him ; but, in the big event, insisted on having his "suv'rin" on a wretched animal which figured among the "any price you like others" division, just because, if you please, the threecornered old skin was named "St. Patrick," and its obscure rider was garbed in a green jacket, bearing the Harp of Erin, "back and front !"

Well, "the patron saint" walked in with the crowd, some two hundred yards behind the rest of the field. Mickey elbowed his way through the seething throng, until he reached the object of his investment ; tapping the jockey on the knee he inquired reproachfully :

"Beggin' yer anner's pardon, phwat detained yez ?" 


\section{CHAPTER XXIV}

T $\mathrm{ARD}$ on the heels of dreams come strange examples of prescience, presentment, telepathy, premonition, or whatever you choose to call those semi-occult, subconscious phenomena which have puzzled scientists from time immemorial.

During one era of my racing career I had a dear and beautiful friend who was of a highly sensitive and receptive nature. She was par excellence a subject for hypnotism and suggestion. I could put her into a trance almost by a look, or a wave of the hand, and when in a hypnotic state, she would make manifest most extraordinary phenomena, among which, for example, she would visualize a race, describe it minutely, and name the colours of the riders. I had not the least belief in her being able to foretell the ultimate result of a contest which had not been run, but out of curiosity I tried how the idea would work out.

My first venture in this direction was on the eve of the Prince's Handicap at Gatwick. I fancied Cabin Boy, belonging to my friend Hanbury, very strongly ; but my " medium " knew nothing of that, or, indeed, the names of any of the horses likely to run.

As soon as she was "off" she began a vivid 267 
description of the race, and how Cabin Boy, whose colours she described correctly (though she was not acquainted with them), won comfortably. This vision was repeated seriatim in the issue.

The fact may not be as astonishing as at first thoughts it might appear, and may have been the result of a telepathy which enabled her to voice my own figuring of what was likely to happen.

The next case is rather more mysterious. I had gone to Goodwood in 1893 for the purpose of backing a certain animal which I fancied at the weights; whilst my friend had remained in London. My selection was not even placed. A passer-by in the paddock informed me that there was a telegram for me on the board. When I retrieved it, it read :

"Medora is certain to win."

It was from my hypnotic subject, and the official time of dispatch was one and a half hours before that set down for the race to be run!

When we met again I questioned her as to the why and wherefore of her wire. She told me that on the day of the Stewards' Cup she had fallen asleep in her boudoir and had seen that race as in a dream, quite clearly and distinctly. A filly with a jockey in all scarlet had won, and on consulting the list of probable runners, as set forth in The Sportsman, she found it was Medora (whose name, so she emphatically informed me, she had never previously heard), whereupon she immediately wired to me as quoted. 
In this case I had no fancy for the bearer of the "Grafton Scarlet," so that evidently telepathy was not responsible for the forecast.

I next tried her for "The Cæsarewitch," and as she named a gee which I thought particularly well handicapped, I had a flutter, but in the issue it was among the "also ran." Henceforth my fair friend firmly refused to act as prophetess, nor did I persist in influencing her to do so ; but in 1896 she had a "presentiment" as regards the result of the Derby, which was certainly remarkable.

Early in the flat-racing season I had run across Hayhoe, who then was training for "Leo" Rothschild.

"You have a very smart string this season, Hayhoe, have you not?" I asked.

"Nuggets, sir-Nuggets!" was his brief reply.

Every horse emanating from that stable carried my money. They kept winning, and as each one "clicked" I put half the winnings on St. Frusquin for the Derby. Therefore when the great day came I stood to win a very nice little packet on the bearer of the blue jacket and yellow cap. My friend had all along shared my confidence in St. Frusquin, but almost at the last moment she implored me to hedge.

"I am very sorry, Cockie, dear," she said, " but St. Frusquin will not win, he will be beaten by Persimmon. I have seen it-I know it!" At first I obstinately stood to my guns, but when I was told that "Mr. Leo" was not present-because it was the anniversary of his 
Grandfather's death *-I began to pay more heed to the oracle of fate and hedged a bit; but I was a loser on the race.

When presentiments materialize in any event, one is apt to regard them with more veneration than perhaps they deserve; but how often is it that these same presentiments turn out to be mere nervous hallucinations. In such cases one sits tight and says nothing about them.

My bad luck over St. Frusquin was an echo of what occurred in I 892 , when half of every bet which I landed went on La Flêche for the Derby. I had a wholesome dread of Orme (for I held a very high opinion of the Duke of Westminster's champion), and was prepared to cover on him. When the numbers went up, the unfortunate and suspicious occurrence which had placed him hors de combat left, as I figured it, a very easy journey open for Baron Hirsch's flyer. But on arriving at Epsom she went all wrong, and was a shadow of herself, which was revealed in the preliminary canter.

History relates how Sir Hugo took her number down. What a lucky gee! What a lucky owner! That poor La Flêche was stones below par, was proved when a moderate filly, such as The Smew, got to her head in The Oaks. At her best, the daughter of

* From this it would seem that Mr. Leo Rothschild " had a hunch" that his colt was doomed to defeat by the Prince's champion. 
St. Simon could have given this one two stone and lost her!

$\dot{A}$ propos St. Simon, this equine wonder was the means of landing me my first substantial wager. To narrate the circumstance I must go back to my salad days.

It was Gold Cup day at Ascot, I884. I had been betting in humble sovereigns to begin with. It was a black Ascot for me when Thursday arrived, for in an attempt to "get home" I had begun what to me, in those days, counted as desperate plunging, and so I found myself over $£ 300$ on the wrong side of the book. A mere trifle you will say, but believe me, I did not so regard it at the time. I consulted a certain noble lord of my acquaintance who had the reputation of being an infallible judge of form. He said :

"I don't advise you to plunge; but there is a certainty to-day. Barring accidents St. Simon is sure to win the Cup."

Of course I myself felt confident of the colt's ability to score, but my friend's pronouncement heartened me to desperation. So I sought out Fry.

"What can I lay you St. Simon for the Cup ?" I asked.

"Take you seven pounds to four, sir." The leviathan was accustomed to my modest investments.

"I'll lay you $£ 700$ to $£ 400$," I said casually.

Fry never moved a muscle of his countenance, but turned quietly to his clerk : 
" Seven hundred to four on St. Simon, Mr. Harding Cox."

You may imagine my feelings during the preliminaries, but they were as nothing to those I suffered during the race. When the small field swung out of the Swinley Bottom and came thundering up the straight, Archer, on the favourite, seemed lost in admiration of the neat polish of his tops. He sat as still as a statue. All the other jockeys were either niggling or hard at work. St. Simon sailed past the post with his ears cocked, but I was not really happy until the "all right" was signalled.

I was nearly $£$ Ioo to the good, and as my luck was evidently in, I had a go on the Friday, and having backed the winner of The Wokingham (at a nice price), and dear old Corrie Roy for The Alexandra Plate, I went home rejoicing.

Here endeth my reminiscences as far as racing and hunting are concerned. 


\section{ENVOI}

10 my everlasting shame I must confess to being one of those miserable creatures who must have a finger in every pie, the savour of which appeals to his appetite. Upon my word, if I were given the choice of beginning all over again, I should be on the horns of a pretty dilemma, and were I allowed the choice of one sport, one pastime, and one artistic occupation, and one only of each, on which I must perforce concentrate all my energies, I could not, for the life of me, come to a decision such as would leave me complacent and content with such choice.

Were I, for instance, to select as my most attractive trio, race-riding, cricket, and painting, I should have strong yearnings towards angling, rowing, and acting; coursing, dog-breeding and exhibiting, and musical composition ; or hunting, billiards, and lyrical effusions; without being able to rid my mind of leanings towards the more essentially sporting forms of shooting.

This kink in my composition betrays the existence of a virulent and chronic complaint known as versatility, which is a veritable curse to those whom it 
attacks. It has its side issues, its by-products, and its complications too. Par exemple, we will say I have finally decided on angling, dog-breeding (including training, exhibiting, and judging), and musical composition. I should, as regards the first, want to cast my lines in all directions ; salmon for choice, then in their declining order, trout, grayling, and all the so-called " coarse" fish, from the voracious pike to the humble gudgeon. But hold! What about sea-fish? Oh yes, I should yearn to hie me to Florida to fight tarpon, or to Santa Catalina in pursuit of tuna, king fish, yellow tails, albacore, sharks, and what not. In our home waters I should want to be after tope, skate, congers, hake, ling, turbot, plaice, pollack, sea-bream, mackerel, whiting, cod, mullet, bass, etc., even including such unconsidered trifles as dabs and pouting.

Then regarding the bow-wows, I should make a bargain with Fate that I was not to be limited to the sporting division alone, or to one breed of sporting dog; I should want to practise my knowledge of canine eugenics on retrievers, spaniels, pointers, and setters ; on bull-dogs, bull-terriers, and fox-terriers; on greyhounds and whippets, just for a start !

Then when it pleased me to exert my talent (alleged) for melody, I should soar to the heights of Parnassus, in an estacy of classical afflatus. But next day syncopated rag-time would occupy the aural stops in my brain. Anon I would wander off into lilting valse refrains and then burst into martial marches, with 
interludes of jigs (Atavistic fancies recurring from a long line of Hibernian ancestors). But I am wanderingrevenons a nos moutons!

This little excursion to the abstract leads me to say a few words as to legitimate sport in general, as distinguished from pastimes and contests.

Our term "sport" covers too much ground, as does its corollary "sportsman." My definition of "sport" for what it is worth, is " an occupation wherein man, with or without the aid of trained animals, sets forth to find his quarry and to kill, or otherwise account for it, in a legitimate manner." Any one so engaged may be termed "a sportsman."

Per Contra. A youth who spends his spare time (and what a lot of it, too!) watching professional football, and betting thereon, may imagine himself a sportsman, but most assuredly he is not! Nor is he who goes to race meetings and criticizes jockeys, when he himself would not throw his leg over a trained racehorse for all the wealth of Ind.

There is the "National Sporting Club." What a misnomer! The institution has nothing whatever to do with sport! Its chief, nay, practically its only, function is to stage boxing shows.

Now boxing is not a sport, even for the principals engaged. It is " a competitive pastime," a most excellent one at that, making, as it does, for skill, pluck, and physical and moral endurance ; but as for the onlookers, who do not possess any of these desirable 
attributes, I am inclined to direct on them the lemon eye of contempt.

Field sports proper consist, to my mind, only of hunting, coursing, falcony, angling, and shooting.

There are forms of the last-named which I would eliminate from the category. Pigeon shooting, i.e. trap shooting, of course ; for its most ardent votaries never claimed it as a sport. It is, or rather was, essentially a trial of skill, with money or other prizes offered for competition; moreover, it cannot be denied that it was a medium for considerable gambling. The Bill which was passed in the summer of $192 \mathrm{I}$ enacted that shooting birds or animals from traps or other contrivances or from the hand is illegal.

The shooting of hand-reared pheasants or wildduck at battues, where the birds are segregated in limited areas, so that they are easily located by the keeper, who is cognizant of their numbers, is a very doubtful "sport." This, too, I should call a trial of skill, and it is only the absence of betting and the award of prizes which raises it above the level of pigeon shooting; for here we have hundreds of one species only, hemmed in with wire netting and prevented from breaking away at awkward points by "stops," i.e. small boys, whose sticks, kept tapping, turn the running pheasants to the right about and send them within the encircling line of beaters. By such methods an efficient drive ensures that the birds can be driven out at practically any desired corner, where the guns are 
so placed that they have every opportunity of proving their quality as "shots." Admittedly the beat is generally so contrived that the birds may get well on the wing and in the full impetus of flight before they fly the gauntlet of shot that awaits them.

Otherwise, where is the difference between a pigeon released from a trap, or a pheasant driven out of cover at a given point? In both cases the birds are the target for a stationary marksman, and in neither has the shooter the sporting pleasure of finding them, or of employing a dog, except as a means of retrieving the casualties.

As for the charge of cruelty and barbarity which has been levelled against pigeon shooting, it is a cry of canting hypocrisy when raised by other votaries of the gun, who delight in a holocaust of pheasant feathers. Believe me, there is far more torture inflicted on the long-tails than on the gentle " doves." I have shot, in my time, thousands of pheasants and thousands of pigeons, and if asked where the greater cruelty occurs, I should say, without hesitation, in the shooting, at battues, of the former. If a pigeon falls within the boundary of the ground, it is quickly retrieved by the dog, and if alive, is skilfully put out of its misery. If it goes away wounded, it seldom passes the "scouts outside," but if it does so, it returns to its loft, is examined by the pigeon purveyor, and if found to be at all seriously wounded is forthwith destroyed.

But what of the pheasant, the victim of an inferior 
elevation, which goes away with both legs shattered, but wings intact? Many a time and oft have I, when shooting shaws and hedgerows, three or four days after a big covert shoot has taken place, come across a wretched pheasant lying helpless in a ditch, in the last throes of thirst and starvation, with its terrible wounds gangrened. Oh yes, I know it is the practice of the keepers to go round with their dogs immediately after a shoot, to collect and despatch the wounded, but the rule is very often more honoured in the breach than in the observation, because, in order to make a clean sweep of casualties, it would be necessary to enter and disturb unshot coverts which had been allocated to another day.

In any case a large proportion of victims are so hidden that they are not discovered, and thus are left to perish miserably; unless perchance, a vagrant fox or stoat comes along to administer the coup de grâce.

On some moors, grouse driving is not a matter of choice, but of necessity; though whenever and wherever the bonnie brown birds can be shot over dogs, the true sportsman will elect so to account for them. I regard, with something bordering on contempt, the driving purist who seriously tells me he would not waste time finding and flushing grouse on their native heather, because they offer such an easy mark that their killing becomes a certainty and consequently wearisome. This is rubbish! The best shot in the world, after shinning up a rugged mountain side 
and wading through knee-high heather, on a hot August afternoon, may well miss, right and left, a brood of grouse rising almost at his feet, even when he has a firm stance; but if he has one foot on a boulder and the other in a moss hole, it is odds that he will do so ! I would give such an one a hundred cartridges and bet him two to one he would not bring home twenty-five brace of grouse-walked up; though he might be sure of producing the percentage at the butts.

The same applies to partridge shooting. I consider the driven partridge, coming down wind in full flight, to offer the greatest test of skill which the gun can be put to. I may say that this form of trial is one which I have not shone at as consistently as I should have desired. Sometimes I have performed almost brilliantly, at others I have shown form which would disgrace a neophyte. Self-confidence is the great thing ! When the eye obeys the brain, and transmits its message to the hand correctly, the gun is thrown up at the proper alignment and a kill follows; but let a shooter miss unexpectedly, and then begin to wonder why, and he is lost ; his confidence is gone, and he begins mentally measuring distances and allowances. $\mathrm{He}$ "pokes" at his birds, with the inevitable consequence that he misses time after time.

Partridge driving has its uses, especially late in the season; but it lacks the joy of setting out on a fine September morning, to begin on an expansive field of roots, with a brace of staunch pointers (which work in 
harmony and back one another faultlessly), and a good retriever or spaniel that will drop to shot and wing, and never leave a runner until it is safe in his tender mouth !

It may be very satisfactory to your stationary shooter to swank, in the evening, how he had two dead rocketters in the air at'once, and doubled up a third with his second gun, and how he had at least fifty birds on the ground at once at that hot corner! The satisfaction may even be more acute, if he has seen his next-door neighbour, that crack shot, Lord Slammenem, blow the tail out of one cock and drop a leg of another.

But give me a boon companion, a staunch pointer, a brace of cockers, and a flat-coated retriever of my own particular breed, and set me on a great expanse of marsh where snipe abound, and duck are frequently met with ; where, on the sides of the heather-clad hills which surround it, grouse can be walked up, and many a woodcock flushed. Give me these conditions, I repeat, and you can have all the pheasant battues and grouse and partridge drives, and all the boasting of your prowess with the shooting iron, that your heart may desire!

Of falconry I know little, but it must be a very pretty sport, and one which requires a great knowledge of nature and skill in training and retaining your birds. 
When I was asked by the Duke of Beaufort * to write on "Coursing" for the Badminton Library, it was decided that "Falconry" should be incorporated in the volume, so that I had an opportunity of studying the sport (on paper) so ably dealt with by the Hon. Gerald Lascelles; but I have never had an ocular demonstration of its thrills, except occasionally when, in the course of my ramblings, I have witnessed an impromptu flight. I have seen a female sparrow-hawk stoop to, and strike, a pigeon ; and a pair of these aggressive hawks outmanœuvre a heron and bring him to earth after a most exciting set-to. The "frankie" would throw himself on his back in the air, and as one of the hawks "stooped," he would attempt to, and nearly succeed in transfixing it with a daggerlike thrust of his lethal bill ; but the end came when the smaller hawk (male) made a flank attack, at the same moment as his mate "stooped" from above. They met on the vile body of the heron, and all three descended, in a cloud of feathers, into a large bed of reeds growing in a foot of water. I ran as hard as I could to the spot, when the heron rose laboriously and much the worse for wear. The male hawk also made off at sight of me ; but where was the big hen ? It is possible that Mr. Heron had skewered her ; though I failed to find anything but a sprinkling of feathers to denote where the trio had landed.

* And also by his representative, my old friend, Alfred Watson, better known as " Rapier " of the Sporting and Dramatic Neros. 
In Egypt I saw quite a lot of natural falconry. No sooner did we commence operations, when out quail shooting, than we were followed by hawks and falcons of many varieties, and these would stoop to the little birds as we flushed them in the most audacious fashion, altogether ignoring the fact that they themseves were in peril of their lives from villainous explosives; but we were so interested and amused by their evolutions that we invariably spared the raiders. 


\section{THE AMATEUR'S DERBY}

\section{By HARDING COX}

An exciting racing novel.

Crown 8vo. 7s. 6d. net. [Ready Shortly.

\section{THE ESCAPING CLUB}

\section{By A. J. EVANS}

The Kent and Test Match Cricketer.

\section{Illustrated. 7s. 6d. net. Sixth Edition.}

"If there is ever another war and Mr. A. J. Evans, the well known Hampshire, Kent and Test Match cricketer, takes part in it, there will probably be strict instructions on the enemy side that in no circumstances is he to be taken prisoner. For he must be an awful nuisance to look after. Indeed, on reading his book, one feels almost sorry for the Germans and Turks who tried to hold him. No more absorbing story of personal experience in war time has ever been told than this cheery narrative.-

Daily Chronicle.

\section{DAYS AND NIGHTS OF SHIKAR}

By Mrs. W. W. BAILLIE Illustrated. Demy 8vo. 12s. 6d. net.

"If these shooting stories had been ascribed, say to Selons, the reader would still have been struck by the intrepidity of the chief actor-by his coolness in danger, his marksmanship, his endurance, and his indifference to discomfort. With the alteration of a few unimportant words, such as pronouns, the sex of the author would be undisclosed. Her book differs from books of the day in that it ignores sex, but none of the many published to prove the equality of the sexes make their point so effectively as this plain statement of what a woman can accomplish in a field of which man had long established himself exclusive proprietor."-Times.

JOHN LANE THE BODLEY HEAD LTD., VIGO ST., W.I 
"The most thrilling volume of the year."-Daily Mail.

\title{
SOME EXPERIENCES OF A NEW GUINEA RESIDENT MAGISTRATE
}

\author{
By CAPT. C. A. W. MONCKTON \\ F.R.G.S., F.Z.S., F.R.A.I.
}

\section{With numerous Illustrations.}

Fourth Edition. Demy 8vo. 21s. net.

"One of the most entertaining books of its kind that we have ever read. Captain Monckton is a born storyteller, and weaves a singularly frank and amusing narrative of his doings. We trust that he will fulfil his promise to write another volume, for he evidently has a great deal more to say about New Guinea and its strange people."-Spectator.

"He was his own surveyor, surgeon, blacksmith, gaoler, and undertaker; he had to perform marriages, and sail crazy ships up and down a reef-studded, shark-haunted coast, and baffle sorcerers usually with some devilment a bit more scientific than their own. For his tales and adventures readers must go to the book, they are too many and various to be summarized, and the verve of of the telling is half the point."-Times.

\section{LAST DAYS \\ IN NEW GUINEA}

Being further Experiences of a New Guinea Resident Magistrate.

By CApt. C. A. W. MONCKTON

Illustrated. Demy 8vo. 18s. net.

JOHN LANE THE BODLEY HEAD LTD', VIGO ST., W.I 



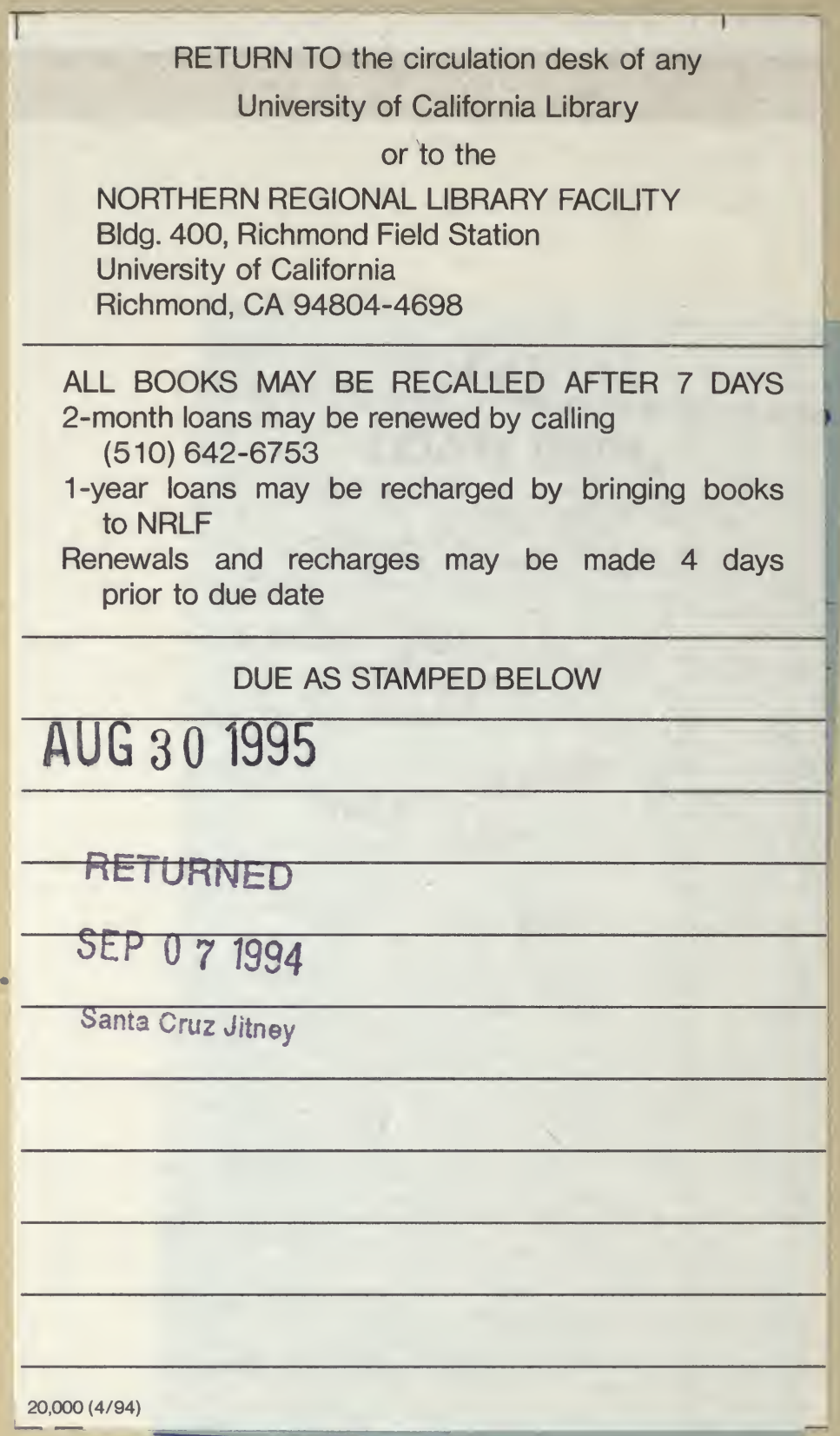


YC 12234 
(a)

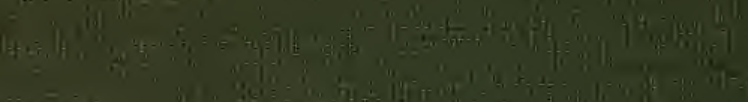

ane

"II I

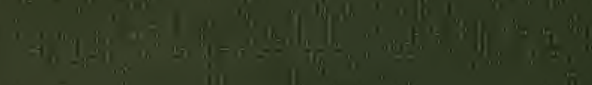

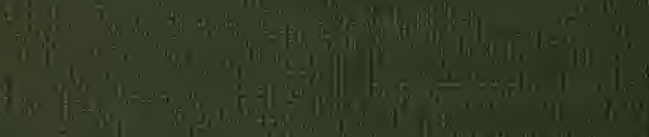

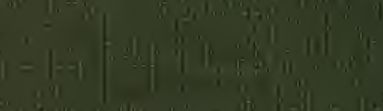

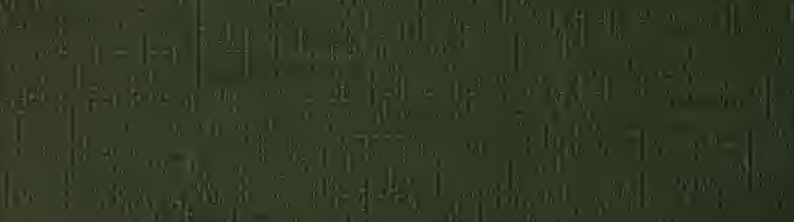

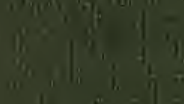

(1)

(I)

(2.) in:

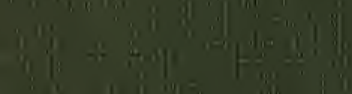

?.

iig.

aic as

(n)

I. If ! I

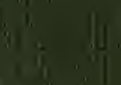

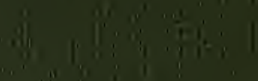

